\title{
A Weather Pattern Climatology of the Great Plains and the Related Wind Regime
}

W. R. Barchet

November 1982

Prepared for the U.S. Department of Energy under Contract DE-AC06-76RLO 1830

Pacific Northwest Laboratory Operated for the U.S. Department of Energy by Battelle Memorial Institute 


\title{
DISCLAIMER
}

This report was prepared as an account of work sponsored by an agency of the United States Government. Neither the United States Government nor any agency thereof, nor any of their employees, makes any warranty, express or implied, or assumes any legal liability or responsibility for the accuracy, completeness, or usefulness of any information, apparatus, product, or process disclosed, or represents that its use would not infringe privately owned rights. Reference herein to any specific commercial product, process, or service by trade name, trademark, manufacturer, or otherwise, does not necessarily constitute or imply its endorsement, recommendation, or favoring by the United States Government or any agency thereof. The views and opinions of authors expressed herein do not necessarily state or reflect those of the United States Government or any agency thereof.

\author{
PACIFIC NORTHWEST LABORATORY \\ operated by \\ BATTELLE \\ for the \\ UNITED STATES DEPARTMENT OF ENERGY \\ under Contract DE-AC06-76RLO 1830
}

\begin{tabular}{|c|c|}
\hline \multirow{2}{*}{\multicolumn{2}{|c|}{ Printed in the United States of America }} \\
\hline \multirow{2}{*}{\multicolumn{2}{|c|}{$\begin{array}{l}\text { Available from } \\
\text { echnical Information Service }\end{array}$}} \\
\hline & \\
\hline \multicolumn{2}{|c|}{$\begin{array}{l}\text { National Technical Information Service } \\
\text { United States Department of Commerce }\end{array}$} \\
\hline \multicolumn{2}{|c|}{5285 Port Royal Road } \\
\hline \multicolumn{2}{|c|}{ Springfield, Virginia 22151} \\
\hline \multirow{2}{*}{\multicolumn{2}{|c|}{$\begin{array}{l}\text { NTIS Price Codes } \\
\text { Microfiche A01 }\end{array}$}} \\
\hline & \\
\hline \multicolumn{2}{|c|}{ Printed Copy } \\
\hline & \\
\hline Pages & Codes \\
\hline $001-025$ & $\mathrm{~A} 02$ \\
\hline 026-050 & $\mathrm{A} 03$ \\
\hline $051-075$ & A04 \\
\hline 076-100 & A05 \\
\hline $101-125$ & A06 \\
\hline $126-150$ & $\mathrm{~A} 07$ \\
\hline $151-175$ & A08 \\
\hline $176-200$ & A09 \\
\hline $201-225$ & A010 \\
\hline $226-250$ & A011 \\
\hline $251-275$ & A012 \\
\hline $276-300$ & A013 \\
\hline
\end{tabular}


W. R. Barchet

November 1982

Prepared for the U.S. Department of Energy under Contract DE-AC06-76RLO 1830

Pacific Northwest Laboratory

Richland, Washington 99352 


\section{ACKNOWLEDGMENTS}

The time series of weather pattern type were produced by Dr. M. Garstang and his team of weather pattern analysts at the University of Virginia under contract to PNL. His contribution of suggestions and reports on his work is gratefully acknowledged. Ms. S. Bradymire at PNL was responsible for the processing of much of the NCC TD1440 data. Typing and assembly of the manuscript by Ms. R. Ellis is also acknowledged.

The preparation and publication of this report has been funded by the U.S. Department of Energy under Contract DE-ACO6-76RLO 1830. 
The meteorology of the Great Plains can be described as a constant progression of air masses, fronts and cyclonic storm systems. Each of these meteorological conditions can be characterized by identifiable isobaric and related weather parameter patterns. Nine such patterns have been defined to type the weather patterns in the Great Plains.

Time series of weather pattern types were produced for 62 stations on the Great Plains. Statistical analyses of these time series produced annual and seasonal frequencies of occurrence of the weather pattern types. Maps of the annual and seasonal frequency of occurrence of weather pattern type are presented for the Great Plains. Persistence and alternation frequencies match what is expected for traveling temperate latitude cyclones, anticyclones and fronts.

The wind regime for stations at which the anemometer height and location was constant (and known) for a minimum of three consecutive years was stratified by weather pattern type. Statistical analyses were made to show the response of the wind to the large-scale distribution of air pressure associated with a weather pattern type. The response of the wind to the weather pattern is a site-specific result of the interaction of the largescale meteorology with local terrain, surface roughness and atmospheric stability. Mean wind speed discriminates between pairs of weather pattern types with better than $75 \%$ confidence for more than two-thirds of the possible pairs of weather pattern types. 


\section{CONTENTS}

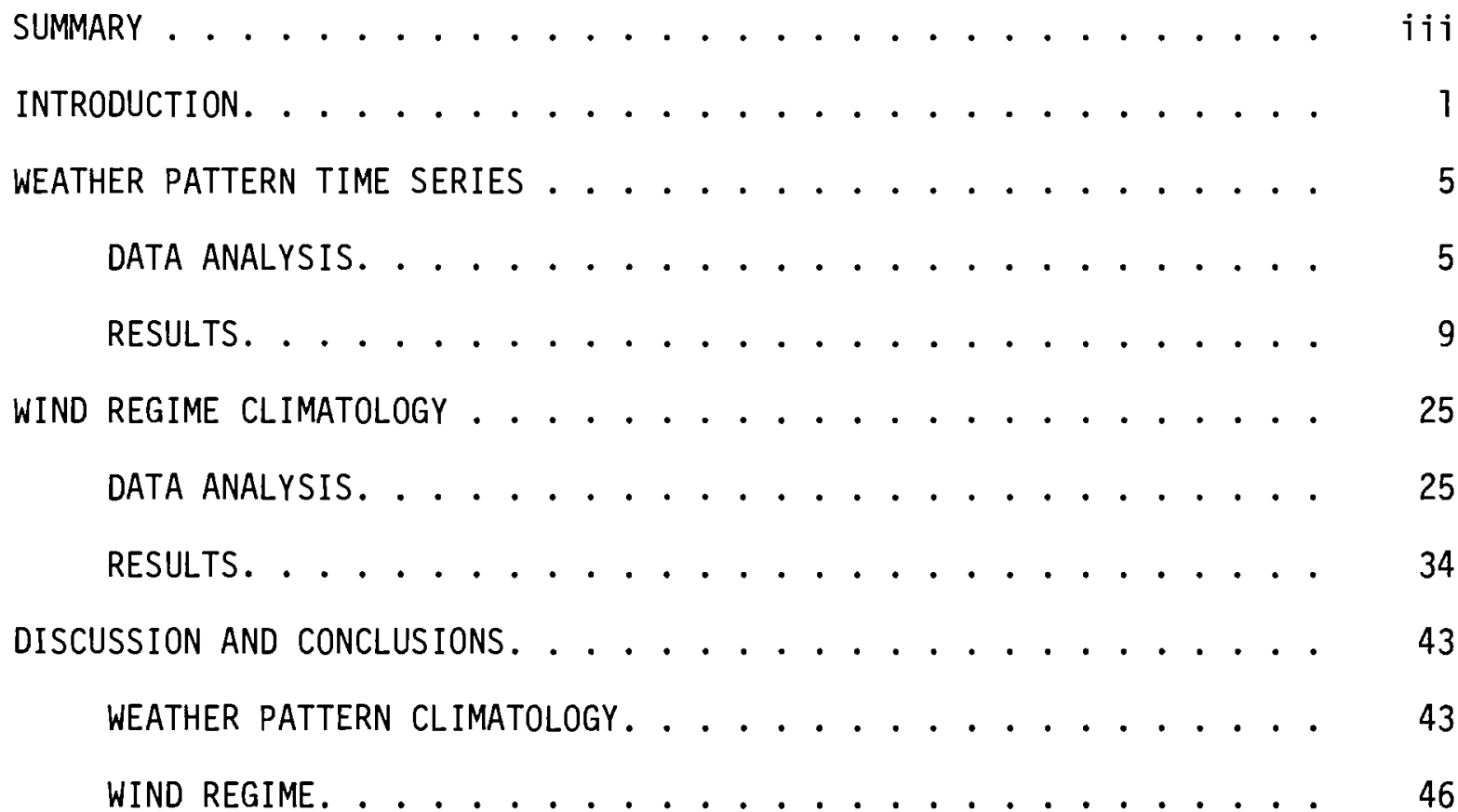





\section{FIGURES}

1 Weather Pattern Types Associated With Synoptic

Weather Features. . . . . . . . . . . . . . .

Distribution of Weather Pattern Annual Frequency of Occurrence Over the Great Plains for the Period January 1, 1955 to December 31, 1964. . . . . . . .

Monthly Distribution of Weather Pattern Frequency of Occurrence for Rapid City, South Dakota . . . . . . .

Monthly Distribution of Weather Pattern Frequency of Occurrence for Oklahoma City, Oklahoma. . . . . . . .

Distribution of Weather Pattern Frequency of Occurrence Over the Great Plains in Winter (December, January February) . . . . . . . . . . . . . . . .

Distribution of Weather Pattern Frequency of Occurrence Over the Great Plains in Spring (March, April, May) . . .

Distribution of Weather Pattern Frequency of Occurrence Over the Great Plains in Summer (June, July, August). . .

Distribution of Weather Pattern Frequency of Occurrence Over the Great Plains in Autumn (September, October, November) ...................

10 Scatter Diagrams by Weather Pattern Type of the Variability of Wind Speed (Ordinate) Versus the Variability of Frequency of Occurrence (Abscissa) . . . . . . . (dashed) and Mean Wind Speed (solid) for Rapid City, South Dakota. . . . . . . . . . . . . . . . . (dashed) and Mean Wind Speed (solid) for Oklahoma City,

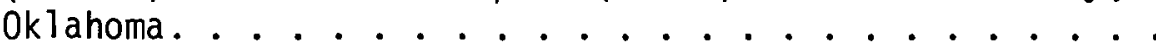


13 Wind Direction Frequency and Mean Wind Speed by Direction for the Period January 1, 1955 to

September 19, 1961 at Helena, Montana . . . . . . .

14 Wind Direction Frequency and Mean Wind Speed by

Direction for the Period September 20, 1961 to

December 31, 1964 at Helena, Montana... . . . . . . 


\section{$\underline{\text { TABLES }}$}

Synoptic $\mathrm{Classes}$ for the Great Plains States . . . . .

List of 62 Stations with Numbers Corresponding to the Numbers in Figure 2, WBAN Station Numbers and Latitude and Longitude. . . . . . . . . . . . . . . . . .

Persistence of Weather Pattern Types at Rapid City, South Dakota, as the Percentage of All Runs for Type With Indicated Duration of Consecutive Observations . . . . .

Frequency of Alternation From Weather Pattern Type I (Row) to Type J (Column) at Rapid City, South Dakota, as the Percentage of Runs of Type I that Change to Type J . . .

Period of Record of the Stations for Which Statistics of the Wind Resource Were Determined . . . . . . . . .

Mean Wind Speed (m/s) and Its Standard Deviation (m/s) at Map Time by Weather Pattern Type. . . . . . . . . . . Deviation (m/s) for 12-Hour Period Centered on Map Time by Weather Pattern Type. . . . . . . . . . . . . .

Mean U-Component $(\mathrm{m} / \mathrm{s})$ and Its Standard Deviation $(\mathrm{m} / \mathrm{s})$ by Weather Pattern Type; $U>0$ From the East . . . . . .

Mean V-Component $(\mathrm{m} / \mathrm{s})$ and Its Standard Deviation $(\mathrm{m} / \mathrm{s})$ by Weather Pattern Type; $V>0$ From the North. . . . . . .

Square Root of Mean Squared Speed $(\mathrm{m} / \mathrm{s})$ and Its Standard Deviation (m/s) by Weather Pattern Type. . . . . . . .

Mean 12-Hour Maximum Wind Speed $(\mathrm{m} / \mathrm{s})$ and Its Standard Deviation $(\mathrm{m} / \mathrm{s})$ by Weather Pattern Type. . . . . . . .

Mean Probability (\%) from 37 Stations That the Mean Wind Speed From the Indicated Pairs of Weather Pattern Types Are From the Same Population of Speed Observations . . . . 
Frequency of Alternation From Weather Pattern Type I (Row) to Weather Pattern Type J (Column) at Carlsbad, New Mexico, as the Percentage of Runs That Change From Type I to Type J. . . . . . . . . . . . . . . . . 


\section{INTRODUCTION}

Measurement of the wind resource at a site is the only approach by which a wind energy planner can make a reliable estimate of the energy production potential of the site. Such measurement programs will, in general, gather data over a period of one to three years. In some regions, where the annual variability of the wind resource is high, an even longer measurement program is needed to make a reliable estimate of the wind resource. This report is the first of a series of reports that addresses the problem of evaluating how well a particular measurement period represents the long-term climatology of wind resource.

The wind resource at a site is the result of the interaction between large-scale weather systems and the physical characteristics of the site. The large-scale weather systems that affect the site set up the pressure gradients that drive the winds. However, the winds also react to features of the terrain, the roughness of the surface and the stability of the atmosphere to produce the wind regime experienced at that site. Measurement of the wind regime records the consequences of the interaction between the large-scale weather systems that affect the site and the local features of the site.

How representative the measurement period is of the long-term climatology will depend on the frequency of occurrence of various weather systems at the site within the period of observation. This report will focus on the climatology of nine distinct weather patterns in the Great Plains. A second report will deal with the problem of adjusting the measured resource to represent the long-term weather pattern climatology. A third report will present a climatology of weather pattern types for the conterminous United States.

The Great Plains was chosen as the study area because of the excellent wind resource over this area of the United States. Furthermore, the large north-south extent of the region, as shown in Figure 1 , and the limited variety of topographic influences on the weather patterns make this an excellent region for testing the utility of weather pattern climatology for adjusting the results of short observation periods to the long-term climatology. 


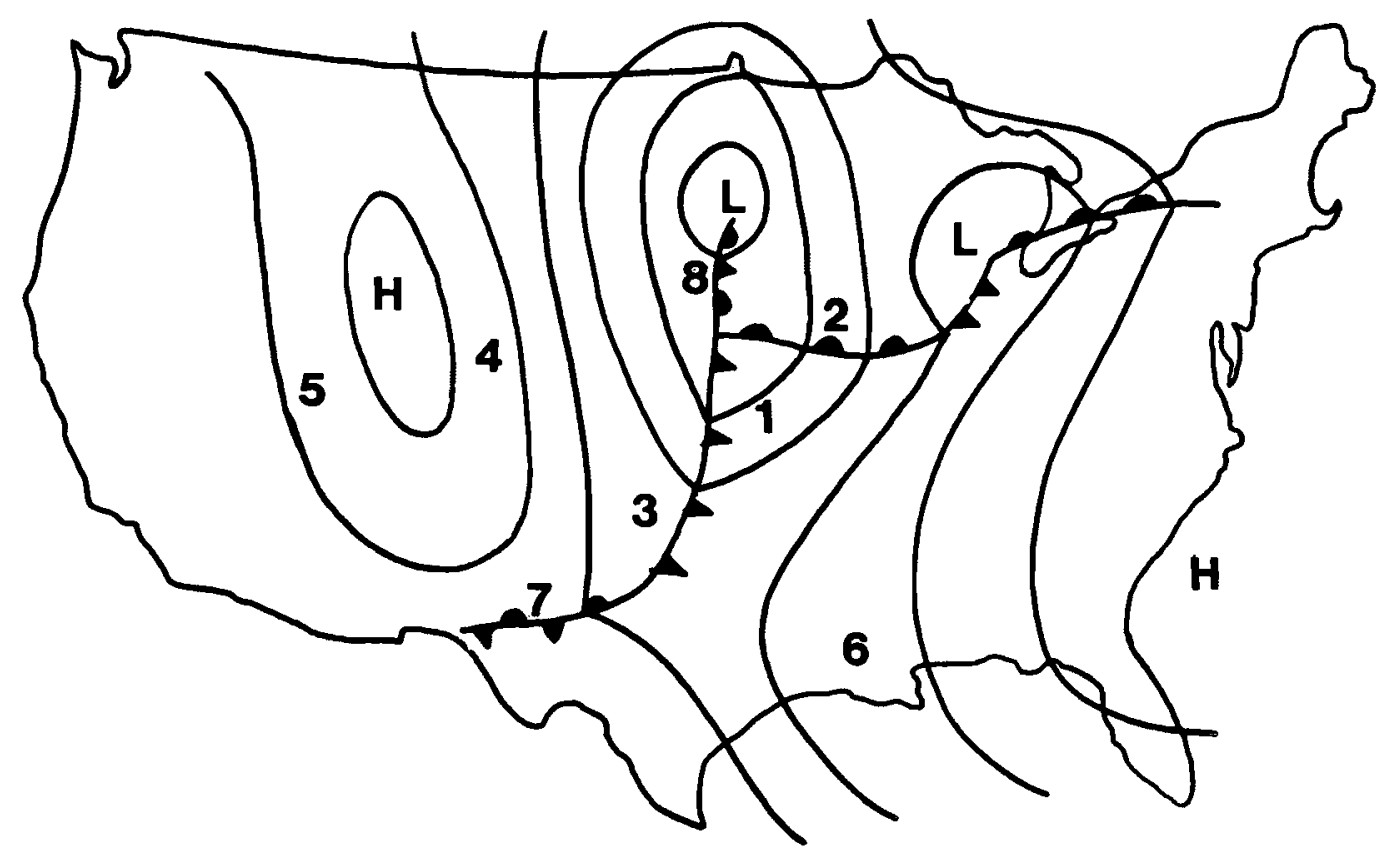

FIGURE 1. Weather Pattern Types Associated With Synoptic Weather Features

Weather patterns over the Great Plains were defined in relation to a standard model of a large-scale weather system positioned over the Great Plains. Figure 1 shows a typical weather system over the Great Plains on which the nine weather pattern types are identified. These patterns are based to a great extent on the distribution of sea-level pressure (isobar patterns) about the weather system. Weather pattern types are related to the various air masses and frontal systems that typically are present in weather systems affecting the Great Plains. Table 1 briefly defines the weather pattern types by their pressure pattern signature and by other factors that help to uniquely identify the pattern. These definitions are very sketchy. Considerable experience in synoptic meteorology is needed to consistently type weather patterns. 
TABLE 1. Synoptic Classes for the Great Plains States

Code

Meteorological Situation

1

Within the warm sector:

- cyclonic curvature of isobars

- component of wind from south

- high humidity

- cumuloform clouds

- some areas of precipitation

- pressure falling

2

Ahead of warm front:

- cyclonic curvature of isobars

- component of winds from east

- high humidity

- stratoform clouds

- continuous precipitation

- pressure falling slowly

3

Behind the cold front:

- cyclonic curvature of isobars

- component of wind from west

- intermediate humidity

- scattered cumuloform clouds

- shower-type precipitation

- pressure rising

4

To the east of continental high:

- anticyclonic curvature of isobars

- component of wind from north

- low humidity

- few clouds

- essentially no precipitation

- pressure steady or rising slowly

5

To the west of continental high

- anticyclonic curvature to isobars

- component of wind from the south

- low humidity

- few clouds

- essentially no precipitation

- pressure steady or rising slowly 
TABLE 1. (Cont.)

Code

6

7

8

9
Meteorological Situation

Under the influence of subtropical (maritime) high:

- anticyclonic curvature of isobars

- component of wind from south

- intermediate to high humidity

- few to intermediate clouds

- some showers especially in afternoon

- pressure steady

In vicinity of stationary front:

- indeterminate curvature of isobars

- light winds

- intermediate humidity

- variable cloudiness

- few areas of precipitation

- pressure steady

In vicinity of occluded front or west of low center:

- cyclonic or indeterminate curvatue of isobars

- component of winds from north

- high humidity

- considerable clouds

- considerable precipitation

- pressure rising slowly

Indeterminate 


\section{WEATHER PATTERN TIME SERIES}

Large-scale weather systems are seldom stationary. They move into, across, and away from the study region in a constant progression of air masses, fronts and cyclonic storm systems. As a result, the weather pattern at a particular location changes with time. The analysis of weather pattern climatology begins with the production of a time series of weather pattern types at sites located throughout the region.

\section{DATA ANALYSIS}

Data for this analysis were in the form of surface weather maps produced twice daily for midnight (0600 GMT) and noon (1800 GMT) Central Standard Time by the National Weather Service and archived at the National Climatic Center. In this study, 7300 weather maps for the period January 1, 1955, through December 31, 1964, were analyzed for 62 stations on the Great Plains. Table 2 lists the stations for which a time series of weather pattern type was produced while Figure 2 shows the location of these stations on the Great Plains.

Although the pressure pattern served as the principal indicator of weather pattern type, it was often necessary to examine secondary features such as the wind direction, cloud cover, humidity, and upper-air pressure patterns to resolve the type. Under some circumstances, no definite type could be unambiguously assigned to the weather pattern. In such cases, Type 9, called "indeterminate", was assigned.

There were some days for which either or both of the maps were "missing" from the archive. Such occurrences were also flagged as a special type. Most missing data occurred sporadically in one-day periods. However, two longer continuous periods of missing weather maps were found: 5 days ending September 17, 1963, and 16 days ending December 31, 1957. Missing data amounted to $1.2 \%$ of a 11 observations.

The time series of weather pattern type were analyzed for 1) the frequency of occurrence of weather pattern type by month, year and period, 
TABLE 2. List of 62 Stations With Numbers Corresponding to the Numbers in Figure 2, WBAN Station Numbers and Latitude and Longitude

\begin{tabular}{|c|c|c|c|c|}
\hline Number & Station Name & WBAN & Latitude & Longitude \\
\hline $\begin{array}{l}\text { A1 } \\
\text { A2 } \\
\text { A3 } \\
\text { A4 } \\
\text { A5 } \\
\text { A6 }\end{array}$ & $\begin{array}{l}\text { Kalispell, MT } \\
\text { Great Falls, MT } \\
\text { Glasgow, MT } \\
\text { Williston/WBO, ND } \\
\text { Minot, ND } \\
\text { International Falls, MN }\end{array}$ & $\begin{array}{l}24146 \\
24143 \\
94008 \\
24014 \\
24013 \\
14918\end{array}$ & $\begin{array}{lll}N & 48 & 18 \\
N & 47 & 29 \\
N & 48 & 13 \\
N & 48 & 09 \\
N & 48 & 16 \\
N & 48 & 34\end{array}$ & $\begin{array}{lrl}W & 114 & 16 \\
W & 111 & 22 \\
W & 106 & 37 \\
W & 103 & 35 \\
W & 101 & 17 \\
W & 93 & 23\end{array}$ \\
\hline $\begin{array}{l}\text { B1 } \\
\text { B2 } \\
\text { B3 } \\
\text { B4 } \\
\text { B5 } \\
\text { B6 } \\
\text { B7 }\end{array}$ & $\begin{array}{l}\text { Helena, MT } \\
\text { Billings, MT } \\
\text { Miles City, MT } \\
\text { Bismarck, ND } \\
\text { Fargo, ND } \\
\text { Alexandria, MN } \\
\text { Duluth, MN }\end{array}$ & $\begin{array}{l}24144 \\
24033 \\
24037 \\
24011 \\
14914 \\
14910 \\
14913\end{array}$ & $\begin{array}{lll}N & 46 & 36 \\
N & 45 & 48 \\
N & 46 & 26 \\
N & 46 & 46 \\
N & 46 & 54 \\
N & 45 & 52 \\
N & 46 & 50\end{array}$ & $\begin{array}{lrl}W & 112 & 00 \\
W & 108 & 32 \\
W & 105 & 52 \\
W & 100 & 45 \\
W & 96 & 48 \\
W & 95 & 23 \\
W & 92 & 11\end{array}$ \\
\hline $\begin{array}{l}\text { C1 } \\
\text { C2 } \\
\text { C3 } \\
\text { C4 } \\
\text { C5 } \\
\text { C6 } \\
\text { C7 }\end{array}$ & $\begin{array}{l}\text { Sheridan, WY } \\
\text { Rapid City, SD } \\
\text { Pierre, SD } \\
\text { Aberdeen, SD } \\
\text { Sioux Falls, SD } \\
\text { Redwood Falls, MN } \\
\text { Minneapolis, MN }\end{array}$ & $\begin{array}{l}24029 \\
24090 \\
24025 \\
14929 \\
14944 \\
14992 \\
14922\end{array}$ & $\begin{array}{lll}N & 44 & 46 \\
N & 44 & 03 \\
N & 44 & 23 \\
N & 45 & 27 \\
N & 43 & 34 \\
N & 44 & 33 \\
N & 44 & 53\end{array}$ & 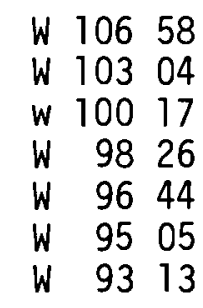 \\
\hline $\begin{array}{l}\text { D1 } \\
\text { D2 } \\
\text { D3 } \\
\text { D4 } \\
\text { D5 }\end{array}$ & $\begin{array}{l}\text { Lander, WY } \\
\text { Casper, WY } \\
\text { Sioux City, IA } \\
\text { Mason City, IA } \\
\text { Dubuque, IA }\end{array}$ & $\begin{array}{l}24021 \\
24089 \\
14943 \\
14940 \\
94908\end{array}$ & $\begin{array}{lll}N & 42 & 49 \\
N & 42 & 55 \\
N & 42 & 24 \\
N & 43 & 09 \\
N & 42 & 24\end{array}$ & 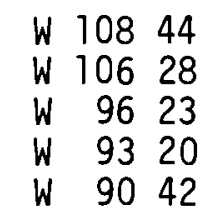 \\
\hline $\begin{array}{l}\text { E1 } \\
\text { E2 } \\
\text { E3 } \\
\text { E4 } \\
\text { E5 } \\
\text { E7 } \\
\text { E8 }\end{array}$ & $\begin{array}{l}\text { Rock Springs, WY } \\
\text { Cheyenne, WY } \\
\text { Scottsbluff, NE } \\
\text { North Platte, NE } \\
\text { Grand Island, NE } \\
\text { Omaha, NE } \\
\text { Des Moines, IA } \\
\text { Burl ington, IA }\end{array}$ & $\begin{array}{l}24027 \\
24018 \\
24028 \\
24023 \\
14935 \\
14942 \\
14933 \\
14931\end{array}$ & $\begin{array}{lll}N & 41 & 36 \\
N & 41 & 09 \\
N & 41 & 52 \\
N & 41 & 08 \\
N & 40 & 58 \\
N & 41 & 18 \\
N & 41 & 32 \\
N & 40 & 47\end{array}$ & $\begin{array}{lrl}W & 109 & 04 \\
W & 104 & 49 \\
W & 103 & 36 \\
W & 100 & 41 \\
W & 98 & 19 \\
W & 95 & 54 \\
W & 93 & 39 \\
W & 91 & 07\end{array}$ \\
\hline
\end{tabular}


TABLE 2. (Cont.)

\begin{tabular}{|c|c|c|c|c|}
\hline Number & Station Name & WBAN & Latitude & Longi tude \\
\hline $\begin{array}{l}\text { F1 } \\
\text { F2 } \\
\text { F3 } \\
\text { F4 } \\
\text { F5 } \\
\text { F6 } \\
\text { F7 }\end{array}$ & $\begin{array}{l}\text { Denver, CO } \\
\text { Akron, CO } \\
\text { Goodland, KS } \\
\text { Hi11 City, KS } \\
\text { Russe11, KS } \\
\text { Concordia, KS } \\
\text { Topeka, KS }\end{array}$ & $\begin{array}{l}23062 \\
24015 \\
23065 \\
93990 \\
93997 \\
13984 \\
13996\end{array}$ & $\begin{array}{lll}N & 39 & 45 \\
N & 40 & 10 \\
N & 39 & 22 \\
N & 39 & 23 \\
N & 38 & 52 \\
N & 39 & 33 \\
N & 39 & 04\end{array}$ & $\begin{array}{lrl}W & 104 & 52 \\
W & 103 & 13 \\
W & 101 & 42 \\
W & 99 & 50 \\
W & 98 & 49 \\
W & 97 & 39 \\
W & 95 & 38\end{array}$ \\
\hline $\begin{array}{l}\text { G1 } \\
\text { G2 } \\
\text { G3 } \\
\text { G4 } \\
\text { G5 } \\
\text { G6 } \\
\text { G7 }\end{array}$ & $\begin{array}{l}\text { Colorado Springs, Co } \\
\text { Pueblo, Co } \\
\text { Trinidad, Co } \\
\text { Dodge City, KS } \\
\text { Wichita, KS } \\
\text { Emporia, KS } \\
\text { Chanute, KS }\end{array}$ & $\begin{array}{l}93037 \\
93058 \\
23070 \\
13985 \\
13998 \\
13989 \\
13981\end{array}$ & $\begin{array}{lll}N & 38 & 49 \\
N & 38 & 17 \\
N & 37 & 15 \\
N & 37 & 46 \\
N & 37 & 38 \\
N & 38 & 20 \\
N & 37 & 40\end{array}$ & $\begin{array}{lrl}W & 104 & 43 \\
W & 104 & 31 \\
W & 104 & 20 \\
W & 99 & 58 \\
W & 97 & 16 \\
W & 96 & 12 \\
W & 95 & 29\end{array}$ \\
\hline $\begin{array}{l}\mathrm{H} 1 \\
\mathrm{H} 2 \\
\mathrm{H} 3 \\
\mathrm{H} 4\end{array}$ & $\begin{array}{l}\text { Raton/Crews, NM } \\
\text { Enid, OK } \\
\text { Oklahoma City, OK } \\
\text { Tulsa, OK }\end{array}$ & $\begin{array}{l}23052 \\
13909 \\
13967 \\
13968\end{array}$ & $\begin{array}{lll}N & 36 & 45 \\
N & 36 & 21 \\
N & 35 & 24 \\
N & 36 & 12\end{array}$ & $\begin{array}{lrr}W & 104 & 30 \\
W & 97 & 55 \\
W & 97 & 36 \\
W & 95 & 54\end{array}$ \\
\hline $\begin{array}{l}\text { I1 } \\
\text { I2 } \\
\text { I3 } \\
\text { I4 } \\
\text { I5 } \\
\text { I6 } \\
\text { I7 }\end{array}$ & $\begin{array}{l}\text { Las Vegas, NM } \\
\text { Tucumcari, NM } \\
\text { Amari110, TX } \\
\text { Altus, OK } \\
\text { Wichita Fal1s, TX } \\
\text { Ardmore, OK } \\
\text { Sherman, TX }\end{array}$ & $\begin{array}{l}23054 \\
23048 \\
23047 \\
13902 \\
13966 \\
13965 \\
13923\end{array}$ & $\begin{array}{lll}N & 35 & 39 \\
N & 35 & 11 \\
N & 35 & 14 \\
N & 34 & 40 \\
N & 33 & 58 \\
N & 34 & 18 \\
N & 33 & 43\end{array}$ & $\begin{array}{lrl}W & 105 & 09 \\
W & 103 & 36 \\
W & 101 & 42 \\
W & 99 & 16 \\
W & 98 & 29 \\
W & 97 & 01 \\
W & 96 & 40\end{array}$ \\
\hline $\begin{array}{l}\mathrm{J} 1 \\
\mathrm{~J} 2 \\
\mathrm{~J} 3 \\
\mathrm{j} 4\end{array}$ & $\begin{array}{l}\text { Carlsbad, NM } \\
\text { Midland, TX } \\
\text { Abilene, TX } \\
\text { Dallas/Love, TX }\end{array}$ & $\begin{array}{l}93033 \\
23023 \\
13962 \\
13960\end{array}$ & $\begin{array}{lll}N & 32 & 20 \\
N & 31 & 56 \\
N & 32 & 26 \\
N & 32 & 51\end{array}$ & $\begin{array}{lrl}W & 104 & 16 \\
W & 102 & 12 \\
W & 99 & 41 \\
W & 96 & 51\end{array}$ \\
\hline
\end{tabular}




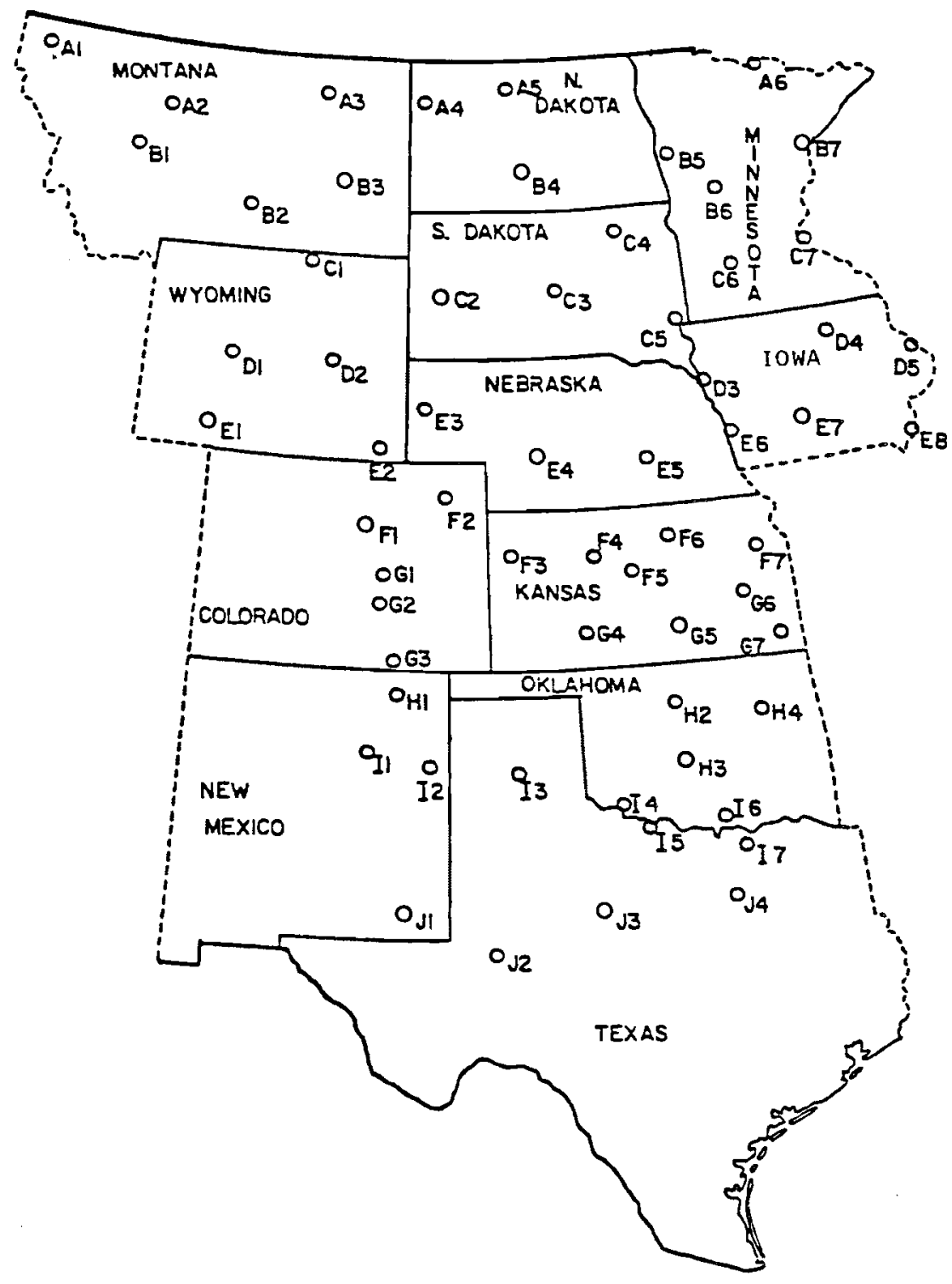

FIGURE 2. Great Plains States and Station Locations. Station numbers correspond to the numbers given in Table 2. 
2) the interannual variability of the frequency of occurrence, 3) the persistence of weather pattern type, and 4) the alteration from one type to another.

\section{RESULTS}

The statistics on the frequency of occurrence of the various weather pattern types were determined for each of the stations over the ten-year period of record. The frequency of occurrence is calculated from the number of observations of a given weather pattern type divided by the total number of nonmissing observations. The frequency of occurrence is the result of the number of times the weather pattern type affects a location, the speed of its movement, and the horizontal extent of the weather pattern type.

Some of these weather pattern types cover a small area (Types 1, 2, 3, and 8 ) and move relatively quickly. The residence time of such types at a particular location is short and the frequency of occurrence is usually low. Types 4, 5 and 6 are associated with high-pressure systems that cover a large area and move slower than the frontal systems; thus, these types have longer residence times and higher frequencies of occurrence. Type 7 covers a small area but moves very slowly (as the term "stationary front" implies), and thus may show a higher frequency of occurrence than Types 2,3 or 8 .

The distribution of the annual frequency of occurrence of the weather pattern types over the Great Plains is shown in Figure 3. The isolines represent lines of constant frequency of occurrence. At any point, the sum of frequencies from all nine weather pattern types totals to nearly $100 \%$.

The monthly variability of weather pattern frequency of occurrence is shown in Figures 4 and 5 for two stations selected to show the dependence of this variability on location. The monthly mean frequency of occurrence is determined by summing the occurrence of each weather pattern type over all days in the month for all years in the period and dividing the sum by the number of nonmissing observations for the month over all years in the period. 

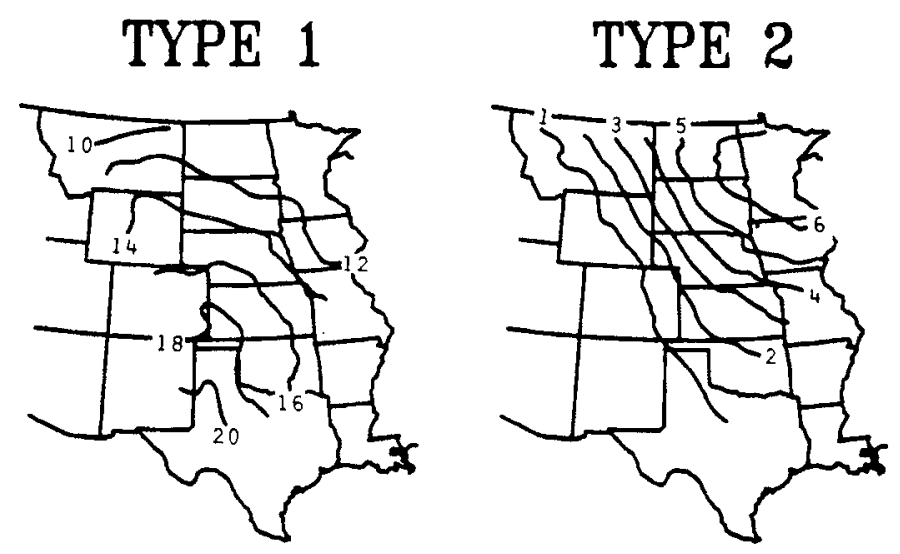

TYPE 3

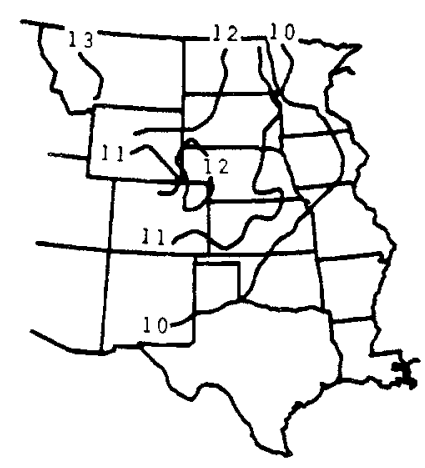

TYPE 4

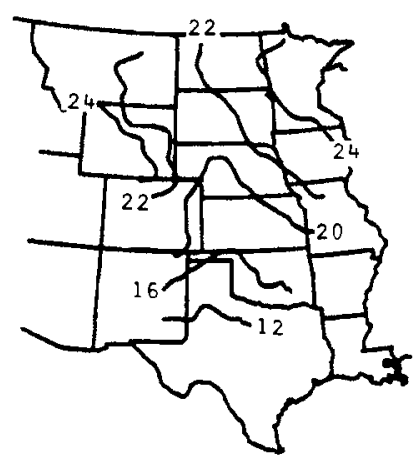

TYPE 5

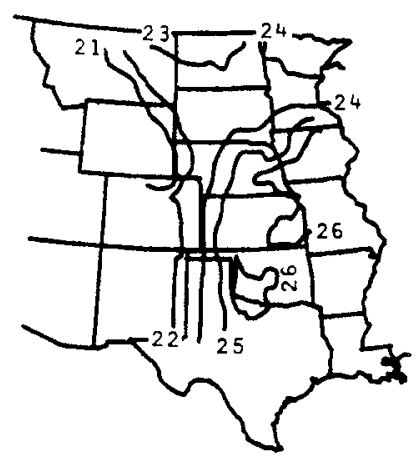

TYPE 6

TYPE 7
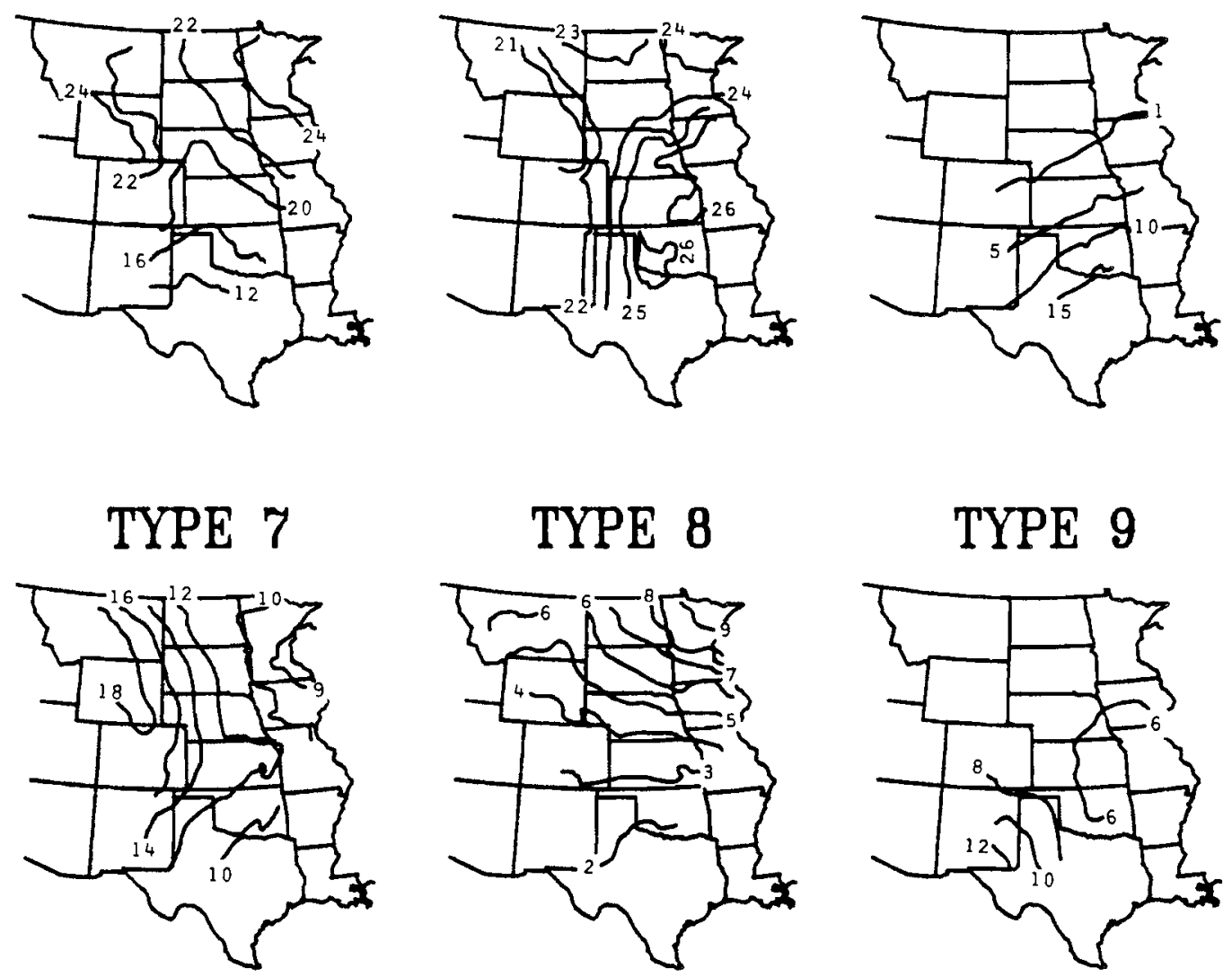

TYPE 9

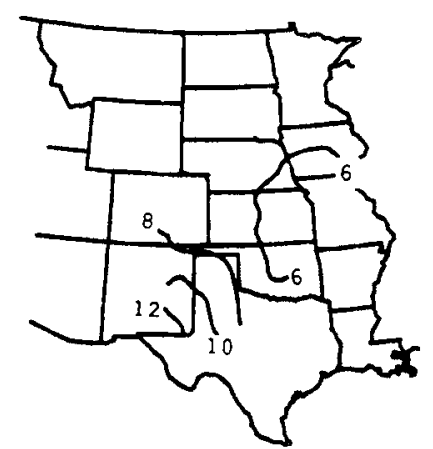

FIGURE 3. Distribution of Weather Pattern Annual Frequency of Occurrence Over the Great Plains for the Period January 1, 1955 to December 31,1964 . Numbers give the percent frequency of occurrence. 


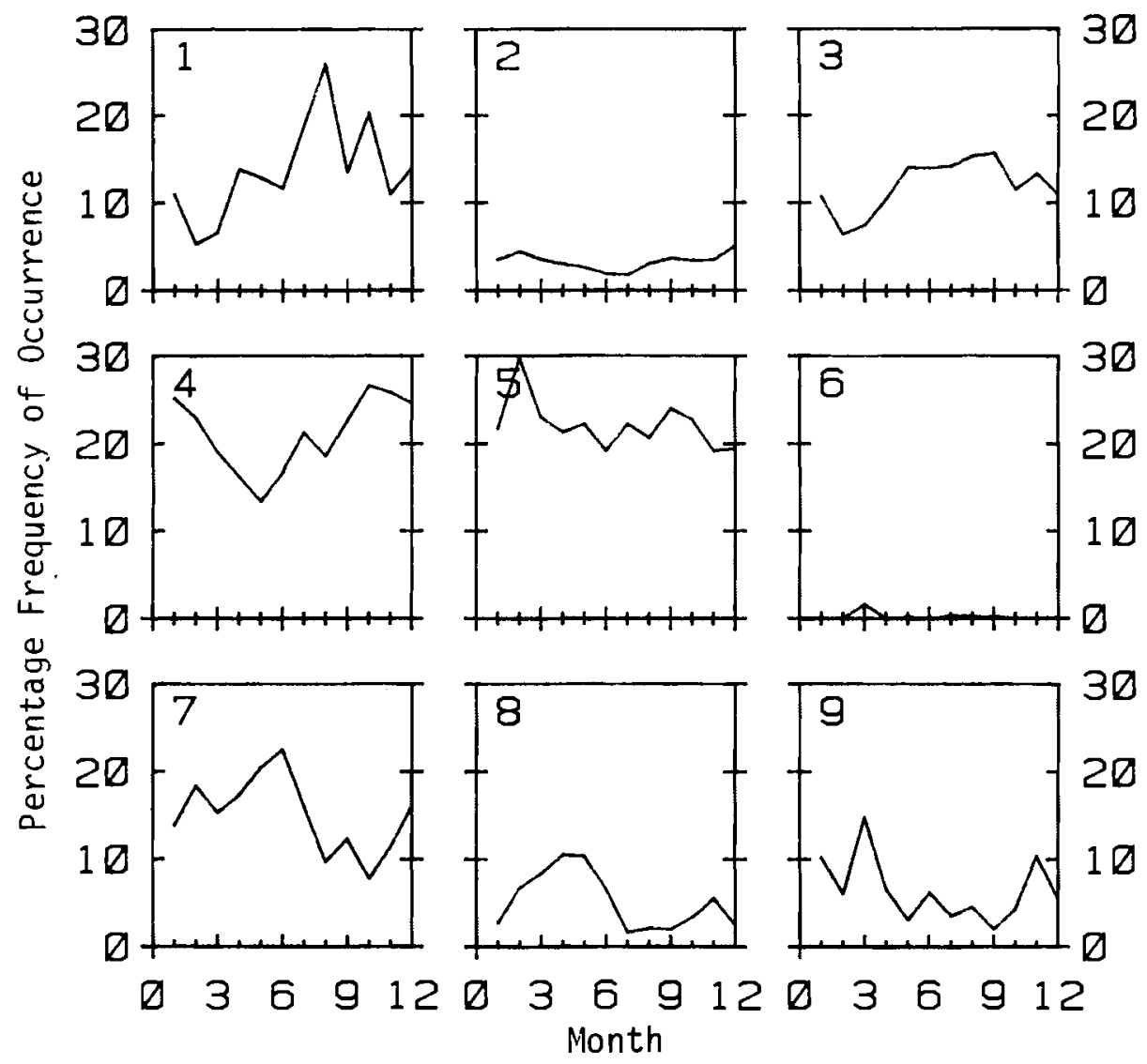

FIGURE 4. Monthly Distribution of Weather Pattern Frequency of Occurrence for Rapid City, South Dakota

The northern High Plains, north of Kansas, is characterized by the seasonal pattern shown for Rapid City, South Dakota, in Figure 4 . In this region, the cold core, continental anticyclone (high pressure system) dominates the weather pattern types. The sum of Types 4 and 5 , both related to the continental high, is nearly $50 \%$. Furthermore, the northerly location of this area results in the nearly complete absence of the subtropical anticyclone, weather pattern Type 6 .

The southern High Plains, Kansas southward, is characterized by the seasonal variations shown for Oklahoma City, Oklahoma, in Figure 5. This area experiences a very large seasonal variation in the occurrence of the major high pressure systems. In winter, the cold, continental polar high (Types 4 


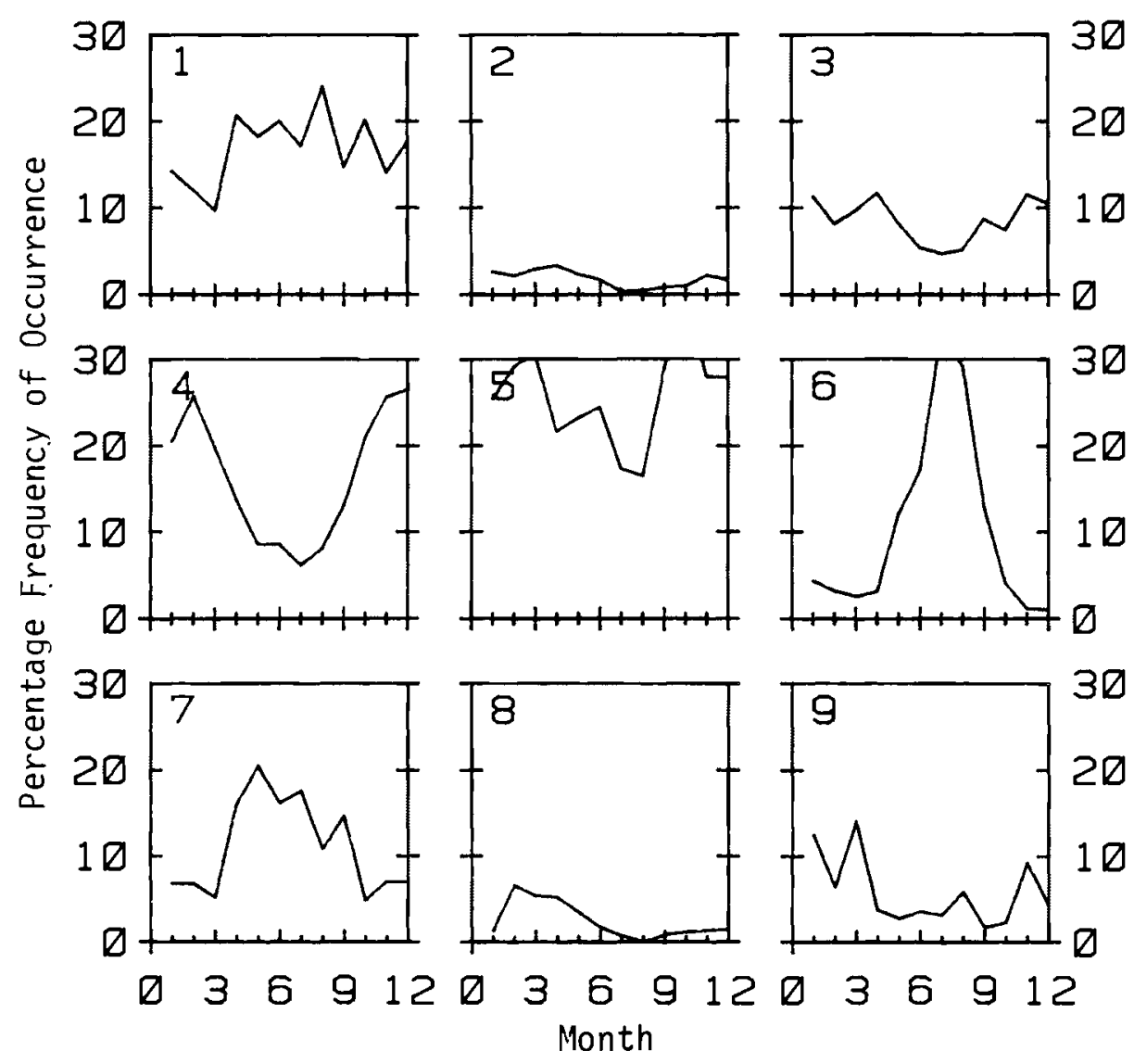

FIGURE 5. Monthly Distribution of Weather Pattern Frequency of Occurrence for Oklahoma City, Oklahoma

and 5) dominates the weather pattern frequency ( $>40 \%)$ while in summer, the warm, humid, subtropical high (Type 6) briefly becomes the dominant weather pattern type. As can be seen in Figure 3, the occurrence of Type 6 diminishes rapidly with distance inland from the Gulf coast.

The seasonal patterns of weather pattern frequency of occurrence over the Great Plains are shown in Figure 6 for winter (December, January, February), Figure 7 for spring (March, Apri1, May), Figure 8 for summer (June, July, August), and Figure 9 for autumn (September, October, November). The seasonal frequencies of occurrence were calculated by averaging the appropriate monthly frequencies. 

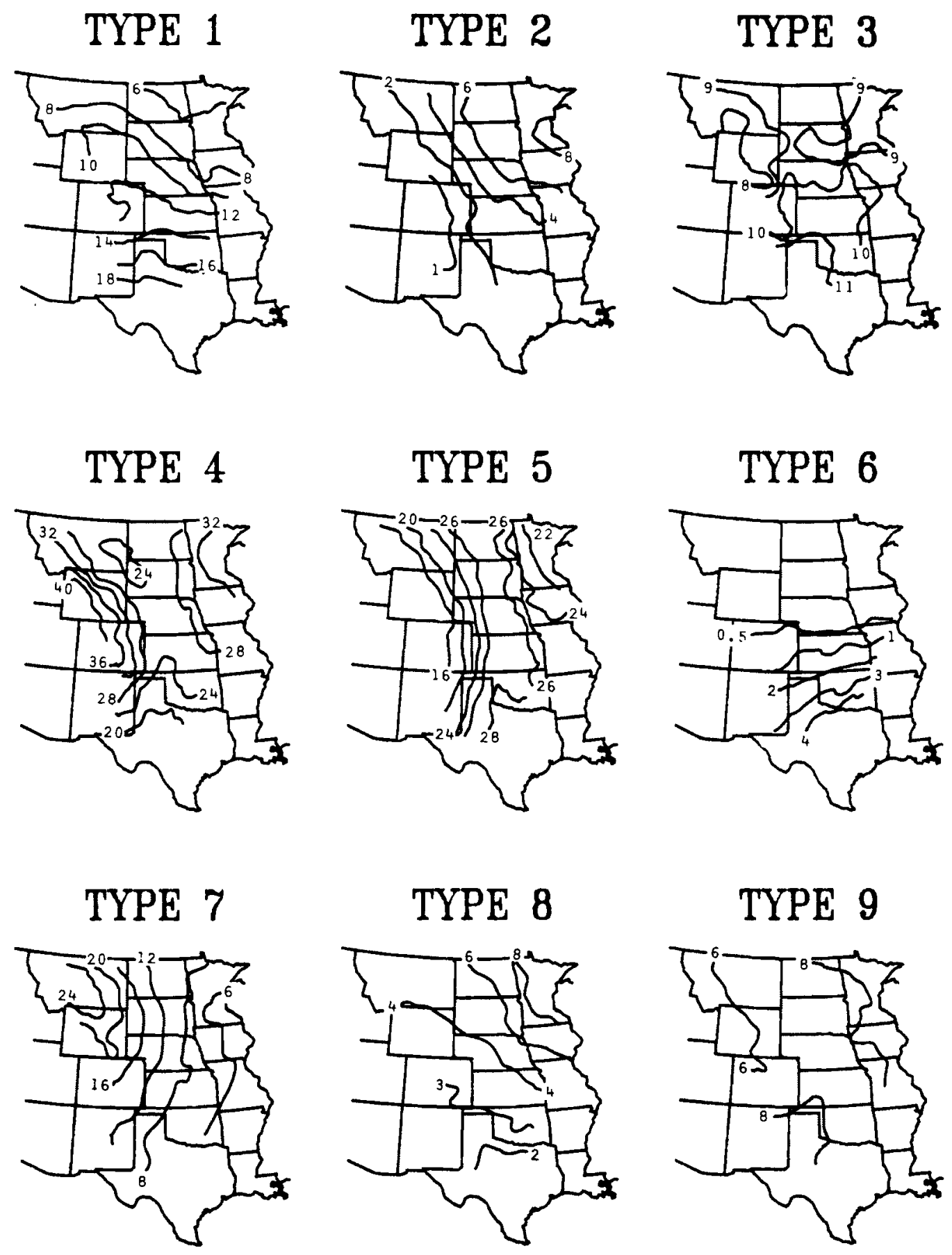

FIGURE 6. Distribution of Weather Pattern Frequency of Occurrence Over the Great Plains in Winter (December, January, February) 

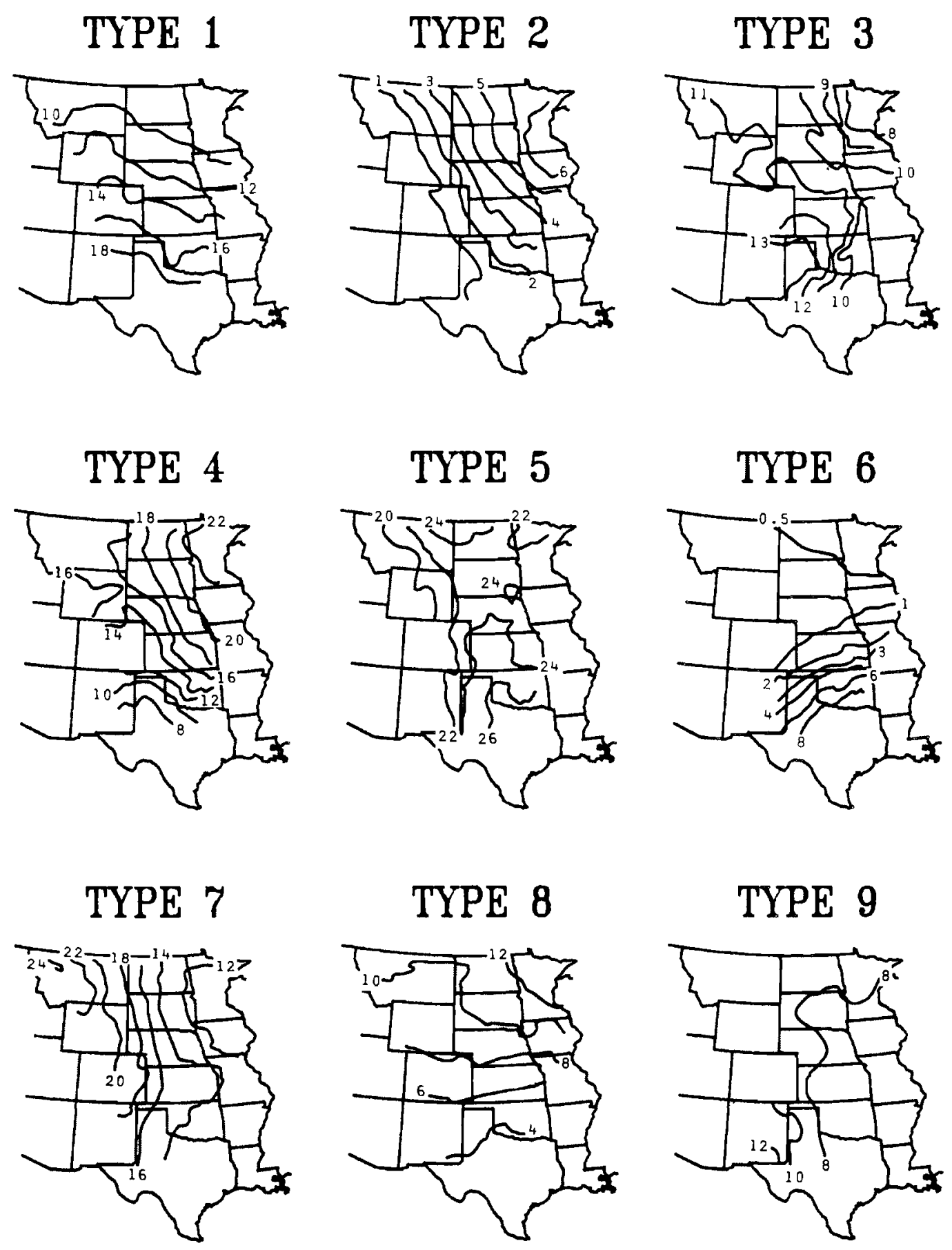

FIGURE 7. Distribution of Weather Pattern Frequency of Occurence Over the Great Plains in Spring (March, April, May) 

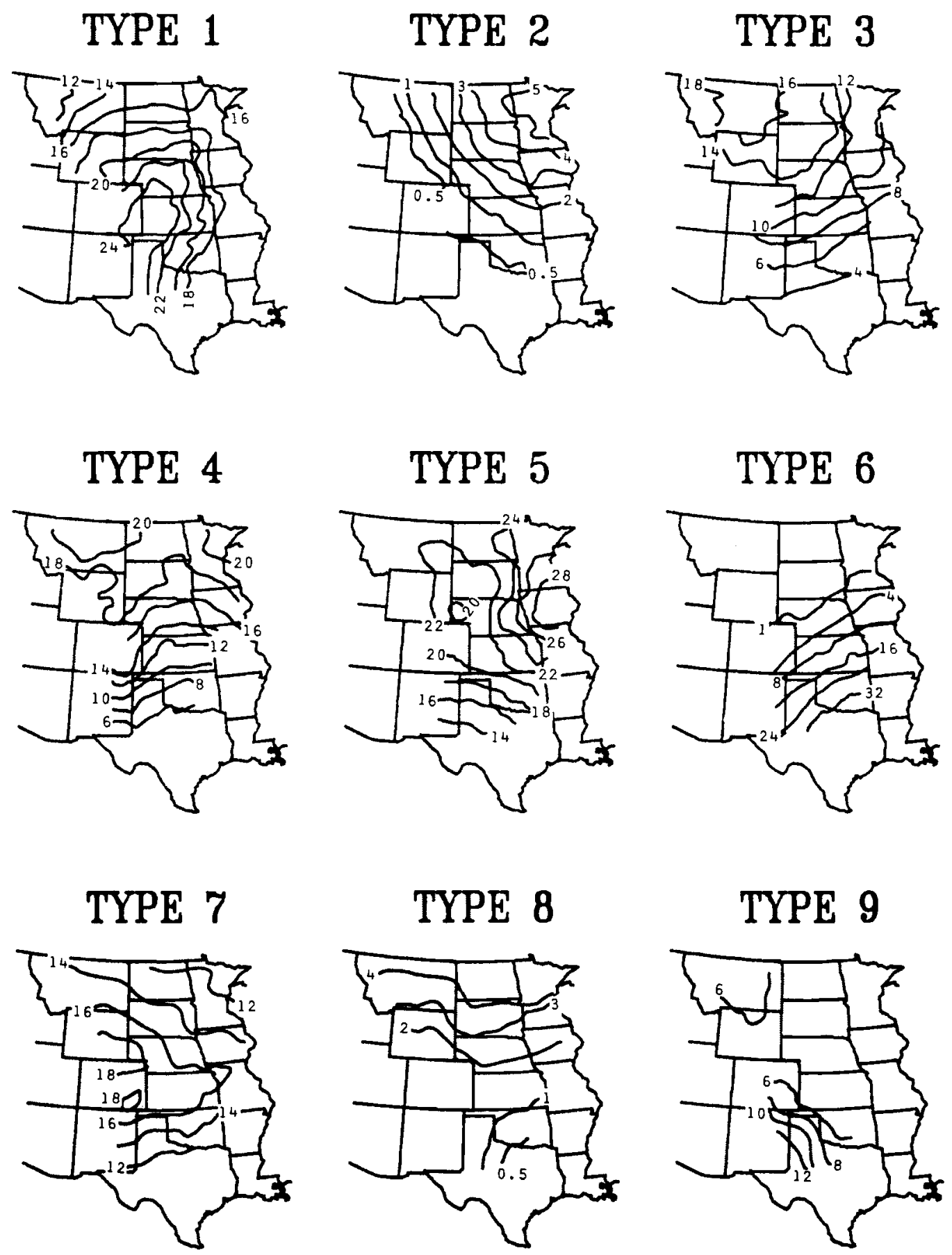

FIGURE 8. Distribution of Weather Pattern Frequency of Occurrence Over the Great Plains in Summer (June, July, August) 

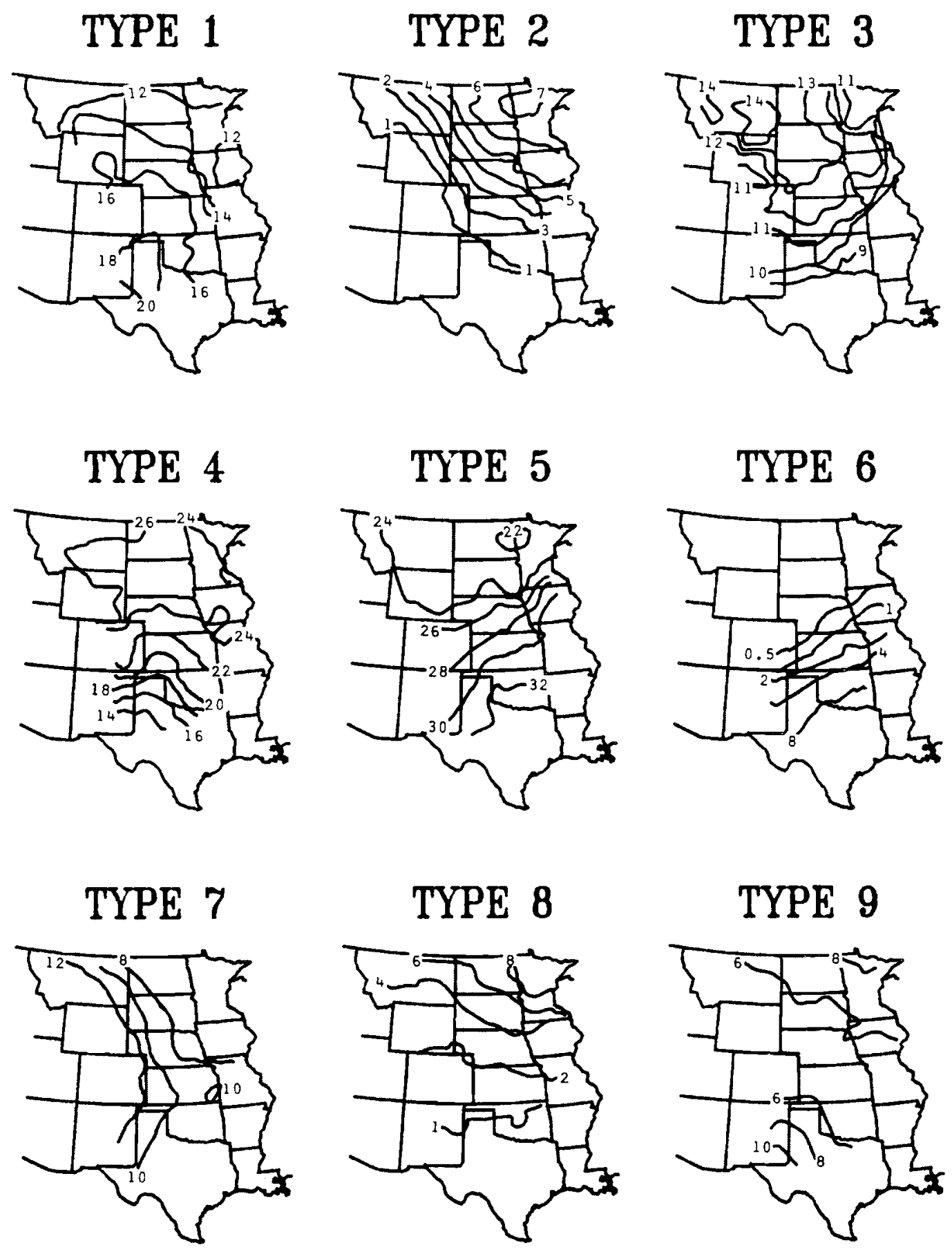

FIGURE 9. Distribution of Weather Pattern Frequency of Occurrence Over the Great Plains in Autumn (September, October, November) 
Winter is dominated by the continental polar high, Types 4 and 5 . The sluggish stationary front, Type 7 , shows a strong influence in the Montana plains. Type 6, the subtropical high, is essentially absent except rarely in the extreme southern plains of Texas. Cold fronts sweep through the plains quickly and are present rather uniformly over all the plains.

In spring, the most noticeable change from winter is in the pattern for Type 4. The disappearance of the anticyclone over the Rocky Mountains and fewer continental polar air masses pushing southward along the Rockies produce a markedly different distribution of frequency isolines and much lower frequencies of occurrence for Type 4 . The springtime influx of subtropical air is noted by the strong gradient in Type 6 over central Texas. Although the frequency of Types 4 and 5 remains high, cyclonic storm activity raises the frequency of frontal patterns (Types 1,3 and 8). The eastward bulge of isolines over Kansas is the transition to the summer pattern and marks the boundary between subtropical air masses and continental polar air masses.

Summer contrasts sharply with the winter patterns. The difference between the northern plains and the southern plains is clearly seen in the orientation of the gradients. For Types 2, 3, and 5, the gradients over the northern plains remain weakly east-west whereas the southern plains have mainly north-south gradients in the frequency of occurrence. But, for Types 1 and 8 , north-south gradients are associated with the northern plains while the east-west gradient in frequency is found in the southern plains. The warm sector, Type 1, attains its maximum frequency and greatest extent of influence over the southern High Plains. Type 6 is also at its highest frequency and northward extent with a strong gradient through the transition region in the Central Plains. This transition region also shows in the pattern of Type 7 , which has its maximum along the southern edge of the transition region. A consequence of the presence of Type 6 is the nearly complete reversal of the gradients in frequency of occurrence of Type 5 . The patterns of isolines for Types 3 and 8 indicate that cyclonic storms travel mostly across the far northern limit of the region. Type 9 attains it maximum frequency over southwestern Texas as a thermal low over the high inland desert of northern Mexico 
creates a pressure pattern in this area that does not fit the model of Figure 1.

Autumn begins the transition back to the winter pattern. East-west gradients are again forming in Types 4 and 5 as these weather pattern types regain dominance and in Type 7 as the frontal systems become more frequent in the northern plains. Type 6 begins to recede and weaken as it is replaced by Type 4 .

Statistics on the persistence of weather pattern type at selected stations were produced for a few locations. Persistence was defined as the number of consecutive observations of the same weather pattern type. Table 3 gives the persistence of weather pattern type at Rapid City. Part A of the table considers persistence between every consecutive observation (map). This is called "composite" because day and night are combined. Since there are two maps per day (midnight and noon), run duration is measured as the number of

TABLE 3. Persistence of Weather Pattern Types at Rapid City, South Dakota as the Percentage of A11 Runs for Type With Indicated Duration of Consecutive Observations

Part A: Persistence for all observations; interval between observations is 12 hours

\begin{tabular}{crrrrrrrrr} 
RUN & \multicolumn{10}{c}{ WEATHER PATTERN TYPE } \\
DURATION & 1 & 2 & 3 & 4 & 5 & 6 & 7 & 8 & 9 \\
1 & 67.8 & 89.4 & 76.1 & 59.9 & 58.6 & 92.9 & 63.7 & 70.4 & 74.0 \\
2 & 20.7 & 10.1 & 17.5 & 20.6 & 20.3 & 7.1 & 20.5 & 18.7 & 16.4 \\
3 & 6.4 & 0.5 & 5.5 & 10.1 & 9.6 & 0.0 & 9.1 & 5.8 & 6.5 \\
4 & 3.3 & 0.0 & 0.3 & 4.8 & 5.8 & 0.0 & 2.8 & 2.7 & 1.5 \\
5 & 0.8 & 0.0 & 0.3 & 2.2 & 2.5 & 0.0 & 2.5 & 1.9 & 0.9 \\
6 & 0.6 & 0.0 & 0.3 & 1.0 & 0.3 & 0.0 & 0.4 & 0.4 & 0.3 \\
7 & 0.0 & 0.0 & 0.0 & 0.8 & 0.9 & 0.0 & 0.4 & 0.0 & 0.0 \\
8 & 0.5 & 0.0 & 0.0 & 0.2 & 0.7 & 0.0 & 0.1 & 0.0 & 0.0 \\
9 & 0.0 & 0.0 & 0.0 & 0.2 & 0.5 & 0.0 & 0.0 & 0.0 & 0.3 \\
10 & 0.0 & 0.0 & 0.0 & 0.0 & 0.0 & 0.0 & 0.1 & 0.0 & 0.0 \\
11 & 0.0 & 0.0 & 0.0 & 0.0 & 0.2 & 0.0 & 0.0 & 0.0 & 0.0 \\
12 & 0.0 & 0.0 & 0.0 & 0.0 & 0.0 & 0.0 & 0.1 & 0.0 & 0.0 \\
RUNS & 658 & 217 & 653 & 858 & 856 & 14 & 673 & 257 & 323
\end{tabular}


TABLE 3 (continued)

Part B: Midnight to midnight persistence; interval between observations is 24 hours

\begin{tabular}{|c|c|c|c|c|c|c|c|c|c|}
\hline RUN & \multicolumn{4}{|c|}{ WEATHER } & \multicolumn{3}{|c|}{ TYPE } & \multirow[b]{2}{*}{8} & \\
\hline DURATION & 1 & 2 & 3 & 4 & 5 & 6 & 7 & & 9 \\
\hline 1 & 77.3 & 94.5 & 84.1 & 68.4 & 62.4 & 75.0 & 69.8 & 79.1 & 76.4 \\
\hline 2 & 16.5 & 5.5 & 13.2 & 21.5 & 24.5 & 25.0 & 17.8 & 14.6 & 15.4 \\
\hline 3 & 4.6 & 0.0 & 2.7 & 6.1 & 7.8 & 0.0 & 8.5 & 5.1 & 5.5 \\
\hline 4 & 1.1 & 0.0 & 0.0 & 2.0 & 3.2 & 0.0 & 2.0 & 1.3 & 0.5 \\
\hline 5 & 0.3 & 0.0 & 0.0 & 1.2 & 1.1 & 0.0 & 1.1 & 0.0 & 2.2 \\
\hline 6 & 0.0 & 0.0 & 0.0 & 0.4 & 0.8 & 0.0 & 0.3 & 0.0 & 0.0 \\
\hline 7 & 0.3 & 0.0 & 0.0 & 0.2 & 0.2 & 0.0 & 0.6 & 0.0 & 0.0 \\
\hline 8 & 0.0 & 0.0 & 0.0 & 0.2 & 0.0 & 0.0 & 0.0 & 0.0 & 0.0 \\
\hline RUNS & 370 & 110 & 365 & 493 & 527 & 8 & 354 & 158 & 182 \\
\hline
\end{tabular}

Part C: Noon to noon persistence; interval between observations is 24 hours

\begin{tabular}{|c|c|c|c|c|c|c|c|c|c|}
\hline RUN & \multicolumn{4}{|c|}{ WEATHER } & \multicolumn{3}{|c|}{ TYPE } & \multirow[b]{2}{*}{8} & \\
\hline DURATION & 1 & 2 & 3 & 4 & 5 & 6 & 7 & & 9 \\
\hline 1 & 75.5 & 97.5 & 85.9 & 67.0 & 66.3 & 100.0 & 69.3 & 74.3 & 75.8 \\
\hline 2 & 18.0 & 1.7 & 10.5 & 21.6 & 22.5 & 0.0 & 19.6 & 22.1 & 18.5 \\
\hline 3 & 3.7 & 0.0 & 2.5 & $7 \cdot 3$ & 6.0 & 0.0 & 7.5 & 2.2 & 2.5 \\
\hline 4 & 2.1 & 0.8 & 1.1 & 2.7 & 3.6 & 0.0 & 2.0 & 1.5 & 3.2 \\
\hline 5 & 0.3 & 0.0 & 0.0 & 0.8 & 1.0 & 0.0 & 1.0 & 0.0 & 0.0 \\
\hline 6 & 0.5 & 0.0 & 0.0 & 0.2 & 0.4 & 0.0 & 0.3 & 0.0 & 0.0 \\
\hline 7 & 0.0 & 0.0 & 0.0 & 0.0 & 0.2 & 0.0 & 0.3 & 0.0 & 0.0 \\
\hline 8 & 0.0 & 0.0 & 0.0 & 0.2 & 0.0 & 0.0 & 0.0 & 0.0 & 0.0 \\
\hline 9 & 0.0 & 0.0 & 0.0 & 0.2 & 0.0 & 0.0 & 0.0 & 0.0 & 0.0 \\
\hline RUNS & 383 & 120 & 362 & 522 & 502 & 5 & 398 & 136 & 157 \\
\hline
\end{tabular}


TABLE 3 (continued)

\begin{tabular}{|c|c|c|c|c|c|c|c|c|c|}
\hline \multirow[b]{2}{*}{$\begin{array}{c}\text { RUN } \\
\text { DURATION }\end{array}$} & o & \multicolumn{4}{|c|}{$\begin{array}{l}\text { noon persisten } \\
\text { is } 24 \text { hours }\end{array}$} & \multicolumn{2}{|c|}{ nterval } & \multicolumn{2}{|l|}{ betwe } \\
\hline & 1 & 2 & 3 & $\underset{4}{E A T H E R}$ & $\begin{array}{l}\text { PATTERN } \\
5\end{array}$ & N $\begin{array}{l}\text { TYPE } \\
6\end{array}$ & 7 & 8 & 9 \\
\hline 1 & 66.8 & 73.3 & 70.0 & 62.0 & 59.1 & 66.7 & 68.0 & 63.6 & 65.2 \\
\hline 2 & 21.1 & 22.9 & 18.5 & 24.2 & 24.3 & 11.1 & 22.0 & 19.6 & 21.9 \\
\hline 3 & 8.3 & 2.9 & 7.4 & 8.6 & 8.5 & 22.2 & 7.1 & 10.5 & 8.6 \\
\hline 4 & 2.6 & 1.0 & 2.9 & $3 \cdot 3$ & 5.3 & 0.0 & 1.9 & 4.2 & 2.7 \\
\hline 5 & 0.3 & 0.0 & 1.2 & 1.0 & 1.4 & 0.0 & 0.6 & 1.4 & 1.1 \\
\hline 6 & 0.0 & 0.0 & 0.0 & 0.3 & 0.8 & 0.0 & 0.0 & 0.7 & 0.5 \\
\hline 7 & 0.6 & 0.0 & 0.0 & 0.8 & 0.4 & 0.0 & 0.3 & 0.0 & 0.0 \\
\hline 8 & 0.0 & 0.0 & 0.0 & 0.0 & 0.0 & 0.0 & 0.0 & 0.0 & 0.0 \\
\hline 9 & 0.0 & 0.0 & 0.0 & 0.0 & 0.0 & 0.0 & 0.0 & 0.0 & 0.0 \\
\hline 10 & 0.3 & 0.0 & 0.0 & 0.0 & 0.2 & 0.0 & 0.0 & 0.0 & 0.0 \\
\hline RUivs & 313 & 105 & 340 & 397 & 494 & 9 & 322 & 143 & 187 \\
\hline
\end{tabular}

Part E: Noon to midnight persistence; interval between observations is 24 hours

\begin{tabular}{|c|c|c|c|c|c|c|c|c|c|}
\hline RUN & \multicolumn{9}{|c|}{ WEATHER PATTERN TYPE } \\
\hline DURATION & 1 & 2 & 3 & 4 & 5 & 6 & 7 & 8 & 9 \\
\hline 1 & 61.4 & 68.8 & 62.6 & 61.4 & 60.8 & 80.0 & 62.7 & 70.2 & 68.4 \\
\hline 2 & 24.1 & 20.5 & 22.4 & $22 \cdot 3$ & 23.2 & 20.0 & 20.5 & 15.8 & $17 \cdot 6$ \\
\hline 3 & $7 \cdot 5$ & 3.6 & 6.4 & 10.8 & 8.6 & 0.0 & $9 \cdot 1$ & 9.6 & $10 \cdot 3$ \\
\hline 4 & 4.3 & 4.5 & 4.8 & $3 \cdot 3$ & 3.9 & 0.0 & 3.4 & 0.0 & 0.7 \\
\hline 5 & 1.7 & 1.8 & 1.3 & 0.9 & 1.7 & 0.0 & 2.3 & 2.6 & 2.2 \\
\hline 6 & 0.6 & 0.0 & 0.6 & 0.7 & 1.1 & 0.0 & 1.4 & 0.0 & 0.7 \\
\hline 7 & 0.3 & 0.9 & 1.3 & 0.0 & 0.3 & 0.0 & 0.3 & 0.0 & 0.0 \\
\hline 8 & 0.0 & 0.0 & 0.6 & 0.2 & 0.0 & 0.0 & 0.0 & 0.9 & 0.0 \\
\hline 9 & 0.0 & 0.0 & 0.0 & 0.2 & 0.6 & 0.0 & 0.3 & 0.9 & 0.0 \\
\hline 17 & 0.0 & 0.0 & 0.0 & 0.2 & 0.0 & 0.0 & 0.0 & 0.0 & 0.0 \\
\hline RUNS & 345 & 112 & 313 & 461 & 362 & 5 & 351 & 114 & 136 \\
\hline
\end{tabular}


consecutive observation increments of 12 hours. A duration of three observations is thus equivalent to 36 hours. The values represent the probability that having had a run of the indicated duration of weather pattern, the next map (or next similar map time) will be some other weather pattern. Diurnal variations in the pressure patterns frequently result in different classifications from day to night although no substantial change in the synoptic situation has occurred. The effect of these diurnal changes can be seen at Rapid City in parts $B$ and $C$ of Table 3 . For these parts of the persistence table, one observation is equivalent to 24 hours. Persistence in real time is much longer when the diurnal variations are "filtered" out. Weather pattern types associated with larger-scale features, e.g., Types 1, 4, 5 and 6 (for more southerly locations) do have significant fractions of runs with durations of several days. The slow-moving and slow-changing stationary front, Type 7 , also shows significant persistence.

The Rapid City persistence pattern shown in Table 3 is representative of much of the Great Plains. Only Type 6 shows a significant change from north (where Type 6 rarely occurs) to south (where Type 6 dominates the summer season). However, the southern Great Plains show a higher percentage of long-run durations than do the northern plains. These longer runs are associated with Types 1, 5, 6 and 7. Stations in the northern Great Plains show a tendency for longer runs with Type 4 than with Type 5 , whereas in the southern plains, Type 5 usually exhibits the longer durations.

The alternation from one weather pattern type to another was also examined for several stations. Table 4 gives the alternation as the percentage of runs of Type I that changed to Type J. Parts A and B of Table 4 give the midnightto-midnight and noon-to-noon alternation. These show essentially similar patterns. Parts $C$ and $D$ give the midnight-to-noon and noon-to-midnight alternation. These measure the diurnal fluctuation in weather pattern type. The values represent the probability that when a run of Type I ends, the next type will be $J$. The last line in each of these parts gives the number of runs for that type. The sum of the runs given in Parts $C$ and $D$ for a weather pattern type equals the total number of runs for that type. The alternation frequencies follow the sequence expected from the synoptic model of Figure 1. 
The only significant regional variation is the frequency of alternation to Type 6 , which shows the strong north to south increase in frequency of occurrence of this weather pattern type.

TABLE 4. Frequency of Alternation From Weather Pattern Type I (Row) to Type J (Column) at Rapid City, South Dakota, as the Percentage of Runs of Type I that Change to Type $J$

\begin{tabular}{|c|c|c|c|c|c|c|c|c|c|}
\hline$\underset{I}{T Y P E}$ & 1 & 2 & 3 & 4 & $\begin{array}{r}T Y P E \\
5\end{array}$ & 6 & 7 & 8 & 9 \\
\hline $\begin{array}{l}1 \\
2 \\
3 \\
4 \\
5 \\
6 \\
7 \\
8 \\
9\end{array}$ & $\begin{array}{r}0.0 \\
11.8 \\
13.2 \\
15.6 \\
25.8 \\
12.5 \\
18.1 \\
8.2 \\
8.8\end{array}$ & $\begin{array}{r}2.7 \\
0.0 \\
5.5 \\
4.9 \\
6.3 \\
12.5 \\
3.7 \\
1.3 \\
3.3\end{array}$ & $\begin{array}{r}34.3 \\
22.7 \\
0.0 \\
8.1 \\
9.7 \\
12.5 \\
19.2 \\
12.7 \\
16.5\end{array}$ & $\begin{array}{r}23.0 \\
17.3 \\
30.1 \\
0.0 \\
19.4 \\
12.5 \\
19.5 \\
31.6 \\
29.1\end{array}$ & $\begin{array}{r}10.8 \\
19.1 \\
23.0 \\
46.5 \\
0.0 \\
0.0 \\
20.1 \\
22.8 \\
23.1\end{array}$ & $\begin{array}{l}0.3 \\
0.0 \\
0.5 \\
0.4 \\
0.0 \\
0.0 \\
0.3 \\
0.6 \\
0.0\end{array}$ & $\begin{array}{r}19.2 \\
19.1 \\
17.0 \\
10.5 \\
18.6 \\
12.5 \\
0.0 \\
14.6 \\
12.6\end{array}$ & $\begin{array}{r}4.3 \\
4.5 \\
5.8 \\
4.1 \\
8.3 \\
12.5 \\
11.6 \\
0.0 \\
4.9\end{array}$ & $\begin{array}{r}4.9 \\
4.5 \\
4.1 \\
9.3 \\
11.2 \\
25.0 \\
6.8 \\
7.6 \\
0.0\end{array}$ \\
\hline RUNS & 370 & 110 & 365 & 493 & 527 & 8 & 354 & 158 & 182 \\
\hline
\end{tabular}

Part B: Noon to noon alternation

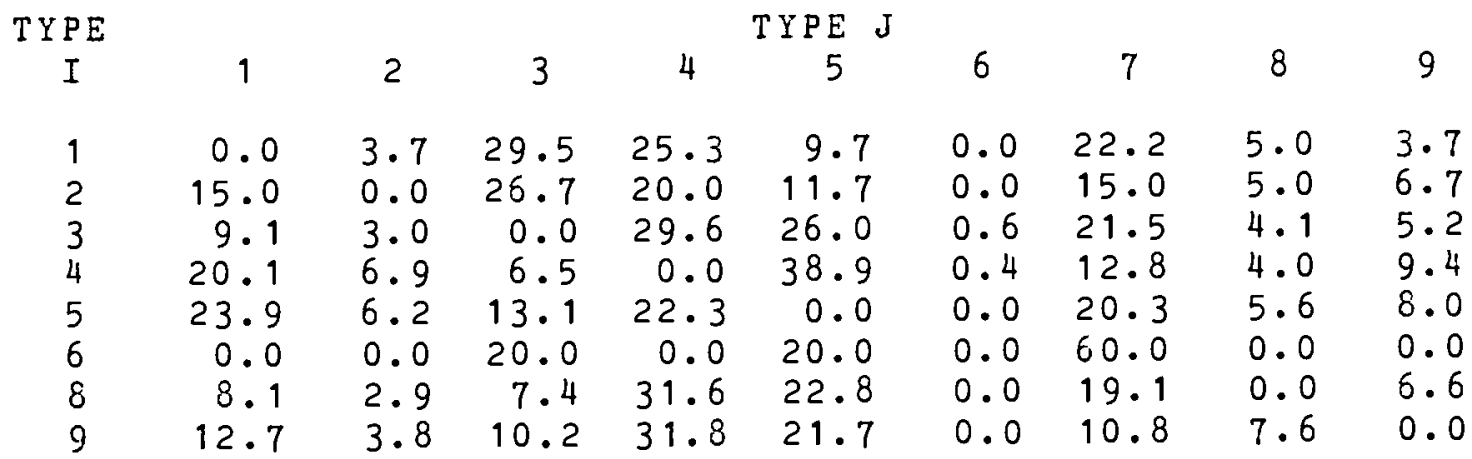

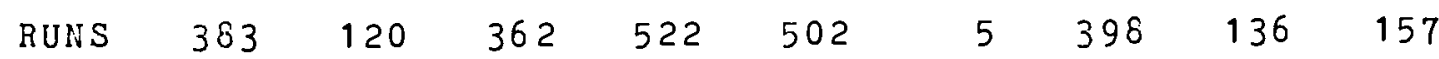


TABLE 4 (continued)

\begin{tabular}{|c|c|c|c|c|c|c|c|c|c|}
\hline TYPE & & & & & TYPE & & & & \\
\hline I & 1 & 2 & 3 & 4 & 5 & 6 & 7 & 8 & 9 \\
\hline 1 & 0.0 & 3.5 & 35.1 & 17.9 & 8.3 & 0.0 & $23 \cdot 3$ & 5.4 & 5.8 \\
\hline 2 & 22.9 & 0.0 & 30.5 & $13 \cdot 3$ & 8.6 & 0.0 & 11.4 & 6.7 & 5.7 \\
\hline 3 & 7.6 & 2.9 & 0.0 & 39.7 & 20.9 & 0.0 & 19.4 & $5 \cdot 3$ & 3.2 \\
\hline 4 & 11.8 & 4.3 & 9.6 & 0.0 & 49.6 & 0.5 & 12.8 & 3.8 & $7 \cdot 3$ \\
\hline 5 & 23.5 & 9.5 & 6.5 & 19.8 & 0.0 & 0.2 & 24.1 & 6.3 & 9.5 \\
\hline 6 & 22.2 & 0.0 & 0.0 & 33.3 & 11.1 & 0.0 & 11.1 & 11.1 & 11.1 \\
\hline 7 & 28.3 & 5.0 & 22.4 & 18.0 & 13.0 & 0.0 & 0.0 & 5.9 & 6.5 \\
\hline 8 & 7.0 & 1.4 & 20.3 & 26.6 & 18.2 & 0.7 & 15.4 & 0.0 & 9.8 \\
\hline 9 & 14.4 & 5.9 & 10.7 & 23.5 & 21.9 & 0.0 & 16.0 & 5.3 & 0.0 \\
\hline RUNS & 313 & 105 & 340 & 397 & 494 & 9 & 322 & 143 & 187 \\
\hline
\end{tabular}

Part D: Noon to midnight alternation

\begin{tabular}{|c|c|c|c|c|c|c|c|c|c|}
\hline TYPE & & & & & TYPE & & & & \\
\hline$I$ & 1 & 2 & 3 & 4 & 5 & 6 & 7 & 8 & 9 \\
\hline 1 & 0.0 & 1.7 & 35.9 & $18 \cdot 3$ & 11.0 & 0.0 & 21.4 & 4.9 & 6.7 \\
\hline 2 & 31.3 & 0.0 & 25.0 & 4.5 & 13.4 & 0.0 & 12.5 & 8.9 & 4.5 \\
\hline 3 & 8.3 & 2.9 & 0.0 & 34.5 & 21.1 & 0.6 & 20.1 & 6.4 & 6.1 \\
\hline 4 & 13.9 & 5.0 & 9.1 & 0.0 & 46.0 & 0.7 & 10.6 & 3.9 & 10.8 \\
\hline 5 & 18.5 & 10.2 & 6.4 & 27.9 & 0.0 & 0.8 & 18.0 & 6.1 & 11.9 \\
\hline 6 & 20.0 & 0.0 & 0.0 & 20.0 & 0.0 & 0.0 & 20.0 & 20.0 & 0.0 \\
\hline 7 & 23.4 & 5.4 & 16.8 & 17.9 & 18.8 & 0.3 & 0.0 & 10.8 & 6.6 \\
\hline$\delta$ & 18.4 & 1.8 & 14.9 & 25.4 & 16.7 & 0.0 & 10.5 & 0.0 & 11.4 \\
\hline 9 & 13.2 & 5.1 & 16.2 & 27.2 & 15.4 & 0.7 & 12.5 & 9.6 & 0.0 \\
\hline RUNS & 345 & 112 & 313 & 461 & 362 & 5 & 351 & 114 & 136 \\
\hline
\end{tabular}




\section{WIND REGIME CLIMATOLOGY}

Every location offers a unique combination of terrain, surface roughness and other obstacles to air flow that results in a very site-specific response of the wind regime to the large-scale meteorology of a weather pattern type. This means that the statistics on the wind regime are site-specific and can not be applied with confidence to other sites. The analyses described below show the general character of the wind regime associated with each weather pattern type. However, they are not meant to describe the wind resource.

DATA ANALYSIS

Stations were selected for an analysis of wind statistics if the period of record with constant anemometer height and location exceeded three years. Only 28 stations ( 37 periods of record) were analyzed in detail. These stations are listed in Table 5 along with the period of record and the anemometer height. For 10 stations, 2 periods at different anemometer heights were analyzed to examine the vertical shear of the long-term wind speed.

Hourly surface weather observations were available in the National Climatic Center TD1440 data set for the 28 stations. Wind data at map time and for the 12-hour period centered on the map time were extracted from the TD1440 surface observations. The wind data and the weather pattern type data were combined into a single data set for each station.

The wind regime for each period of record was stratified according to the weather pattern type and analyzed for monthly, yearly and periodic means, frequency distributions and variability. Tables 6 through 12 summarize various wind statistics for the stations and periods listed in Table 5. All speeds are in $\mathrm{m} / \mathrm{s}$. Tables 8 and 9 give the mean $U$ and $V$ components to the wind. Winds from the east have $U>0$; winds from the north have $V>0$. 
TABLE 5. Period of Record of the Stations for Which Statistics of the Wind Resource Were Determined

\begin{tabular}{|c|c|c|c|c|c|}
\hline WBAN & Station & State & $\begin{array}{l}\text { Start } \\
\text { Period } \\
\end{array}$ & $\begin{array}{l}\text { End } \\
\text { Period }\end{array}$ & $\begin{array}{l}\text { Anemometer } \\
\text { Height (ft) }\end{array}$ \\
\hline 93037 & Colorado Springs & $\mathrm{CO}$ & 580220 & 641231 & 22 \\
\hline 23062 & Denver/Stapleton & $\mathrm{CO}$ & 550101 & 600707 & 72 \\
\hline 23062 & Denver/Stapleton & $\mathrm{CO}$ & 600708 & 641231 & 20 \\
\hline 93058 & Pueblo & $\mathrm{CO}$ & 550101 & 620318 & 34 \\
\hline 14933 & Des Moines & IA & 550617 & 610629 & 69 \\
\hline 14933 & Des Moines & IA & 610630 & 641231 & 20 \\
\hline 14940 & Mason City & IA & 550101 & 641231 & 20 \\
\hline 23065 & Goodland & KS & 550101 & 640322 & 31 \\
\hline 13996 & Topeka & KS & 550101 & 640809 & 72 \\
\hline 14922 & Minneapol is & MN & 580918 & 641231 & $2 \overline{1}$ \\
\hline 24143 & Great Falls & MT & 550101 & 590202 & 75 \\
\hline 24143 & Great Falls & MT & 590202 & 641231 & 22 \\
\hline 24144 & Helena & MT & 550101 & 610919 & 44 \\
\hline 24144 & Helena & MT & 610920 & 641231 & 20 \\
\hline 14935 & Grand Is land & NE & 550101 & 611201 & 47 \\
\hline 14935 & Grand Island & NE & 611202 & 641231 & 20 \\
\hline 24023 & North Platte & NE & 550101 & 640811 & 32 \\
\hline 24028 & Scottsbluff & NE & 550101 & 640801 & 50 \\
\hline 24011 & Bismarck & ND & 550101 & 611016 & 43 \\
\hline 23052 & Raton/Crews & NM & 551101 & 641231 & 22 \\
\hline 23048 & Tucumcari & NM & 550101 & 590917 & 32 \\
\hline 23048 & Tucumcari & NM & 590918 & 641231 & 22 \\
\hline 13902 & Altus & OK & 560803 & 641231 & 12 \\
\hline 13967 & Oklahoma City & OK & 550101 & 641231 & 55 \\
\hline 13968 & Tutsa & OK & 560224 & 601227 & 39 \\
\hline 13968 & Tutsa & OK & 601228 & 641231 & 23 \\
\hline 24090 & Rapid City & SD & 550101 & 641231 & 32 \\
\hline 14944 & Sioux Falis & SD & 560418 & 611124 & 55 \\
\hline 23047 & Amaril10 & $T X$ & 561028 & 610502 & 33 \\
\hline 23047 & Amari110 & $T X$ & 610503 & 641231 & 23 \\
\hline 13960 & Dallas/Love & $T X$ & 580429 & 641231 & 20 \\
\hline 23023 & Midland & $T X$ & 550101 & 591203 & 35 \\
\hline 23023 & Midland & $T X$ & 591204 & 641231 & 22 \\
\hline 24089 & Casper & WY & 580130 & 640811 & 29 \\
\hline 24027 & Rock Springs & WY & 550101 & 600726 & 50 \\
\hline 24027 & Rock Springs & WY & 600727 & 641231 & 20 \\
\hline 24029 & Sheridan & WY & 580610 & 640902 & 42 \\
\hline
\end{tabular}

Dates are given as YYMMDD, $Y Y=y e a r, M M=$ month, $D D=d a y$. 
TABLE 6. Mean Wind Speed $(\mathrm{m} / \mathrm{s})$ and Its Standard Deviation $(\mathrm{m} / \mathrm{s})$ at Map Time by Weather Pattern Type

\begin{tabular}{|c|c|c|c|c|c|c|c|c|c|c|c|c|c|c|c|c|c|c|}
\hline STATION & - & -- & -- & -- & ---3 & - & --- & - & $\cdots$ & $\ldots$ & $\cdots$ & & 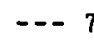 & & -1 & & - & \\
\hline W13 & 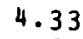 & 2.91 & 4.29 & 2.93 & 4.8 & 2.94 & 3. & 2.51 & 3. & 2.65 & & 2.50 & 4.42 & 2.85 & & 2.30 & 4.32 & $s$. \\
\hline$W 13$ & .63 & 2.45 & 5.59 & 2.25 & 5.24 & 2.נת & 4.61 & 2.45 & 4.9 & 2.31 & 4.9 & 1.97 & 5.33 & 2.28 & & & 5.40 & 2.76 \\
\hline w1 & .39 & 2.51 & 6.15 & 2.82 & 6.2 & 2.89 & 5.46 & 2.3 & 5.6 & 2.2 & 5. & 2. & & 2. & & & 6.15 & 3.03 \\
\hline & & 2.60 & 4.35 & 2.77 & 4.88 & 3.0 & 4.01 & 2.6 & & 2.2 & & 2.03 & 4.3 & 2.45 & & & 4.86 & 3.07 \\
\hline W1 & 5.60 & 2.62 & 5.03 & 2.43 & 5.20 & 2.07 & 4.61 & 2.31 & 4.7 & 2.21 & 4.67 & 1.96 & 4.84 & 2.44 & 5.83 & 2.22 & 5.32 & 2.51 \\
\hline$w_{1}$ & .70 & 3.19 & 5.95 & 2.94 & 5.68 & 2.99 & 4.68 & 2.54 & 4.9 & 2.7 & 5. & 3.01 & 5.31 & 2.90 & 6.30 & 2.96 & 5.29 & 3.07 \\
\hline $\begin{array}{l}W 1 \\
W 1\end{array}$ & .7 & 2. & 4.97 & $\begin{array}{r}2.53 \\
2.73\end{array}$ & 5.20 & 2.77 & 4.10 & 2.32 & 4.0 & 2.32 & & 2.27 & 4.65 & 2.40 & 5.11 & 2.61 & 4.79 & 2.79 \\
\hline $\begin{array}{l}W 14 \\
W 14\end{array}$ & $\begin{array}{r}.34 \\
.89\end{array}$ & $\begin{array}{l}2.80 \\
2.83\end{array}$ & $\begin{array}{l}5.87 \\
3.86\end{array}$ & $\begin{array}{l}2.73 \\
2.50\end{array}$ & $\begin{array}{l}6.07 \\
4.71\end{array}$ & $\begin{array}{l}2.72 \\
2.49\end{array}$ & $\begin{array}{l}4.81 \\
4.02\end{array}$ & $\begin{array}{l}2.32 \\
2.34\end{array}$ & 4.7 & 2.00 & 4.8 & 2.26 & 5.04 & 2.47 & 6.32 & 2.85 & 5.60 & 2.78 \\
\hline & .91 & 2.79 & 6.19 & 2.70 & 5.85 & 2.77 & 5.01 & 2.32 & 5.27 & $\begin{array}{l}2.20 \\
2.50\end{array}$ & $\begin{array}{l}3.91 \\
5.31\end{array}$ & $\begin{array}{l}1.94 \\
2.28\end{array}$ & $\begin{array}{l}4.02 \\
5.71\end{array}$ & $\begin{array}{l}2.44 \\
2.87\end{array}$ & $\begin{array}{l}5.12 \\
6.92\end{array}$ & $\begin{array}{l}2.91 \\
3.00\end{array}$ & $\begin{array}{l}4.49 \\
5.77\end{array}$ & $\begin{array}{l}2.56 \\
2.77\end{array}$ \\
\hline$w 1$ & 5.59 & 2.72 & 5.48 & 2.59 & 5.19 & 2.46 & 4.60 & 2.56 & 4.8 & 2.33 & 4.44 & 2.59 & & 2.93 & & $3 .<0$ & 5.29 & 2.03 \\
\hline & $\begin{array}{r}.52 \\
.70\end{array}$ & $\begin{array}{l}2.71 \\
2.66\end{array}$ & 5. & $\begin{array}{l}3.01 \\
2.99\end{array}$ & 5. & 2.64 & 4.92 & 2.55 & 4.77 & 2.51 & 4.91 & 2.65 & 5.13 & 2.77 & 6.54 & 3. & 5.61 & 2.99 \\
\hline W2 & 4.25 & 2.38 & $\begin{array}{l}2.54 \\
4.34\end{array}$ & 2.34 & $\begin{array}{l}5.35 \\
4.97\end{array}$ & $\begin{array}{l}2.97 \\
2.33\end{array}$ & & $\begin{array}{l}2.66 \\
2.10\end{array}$ & $\begin{array}{l}4.28 \\
4.07\end{array}$ & $\begin{array}{l}2.49 \\
2.24\end{array}$ & $\begin{array}{l}4.96 \\
3.72\end{array}$ & $\begin{array}{l}2.61 \\
2.13\end{array}$ & $\begin{array}{l}4.74 \\
4.44\end{array}$ & $\begin{array}{l}2.59 \\
2.31\end{array}$ & & $\begin{array}{l}3 . \\
2 .\end{array}$ & $\begin{array}{l}5.17 \\
4.31\end{array}$ & $\begin{array}{l}3.33 \\
2.22\end{array}$ \\
\hline W23 & .05 & 2.52 & 5.04 & 2.79 & 5.37 & 2.75 & 4. & 2.49 & 4.69 & 2.36 & 4.50 & 2.26 & 5.40 & 2.6 & & 2. & 4.88 & 2.46 \\
\hline & .05 & & 5.39 & $\begin{array}{l}2.01 \\
2.20\end{array}$ & 34 & 2.78 & 5. & 2.8 & 5 . & 2.53 & 5.02 & 2.17 & 5.76 & 2.5 & 6. & 2. & 5.71 & 3.02 \\
\hline $\begin{array}{l}W 23 \\
W 23\end{array}$ & $\begin{array}{r}.42 \\
.74\end{array}$ & $\begin{array}{l}2.79 \\
2.70\end{array}$ & $\begin{array}{l}4.97 \\
5.33\end{array}$ & $\begin{array}{l}2.29 \\
3.43\end{array}$ & $\begin{array}{l}6.50 \\
5.58\end{array}$ & $\begin{array}{l}3.08 \\
2.78\end{array}$ & $\begin{array}{l}5 . \\
4 .\end{array}$ & $\begin{array}{l}2.82 \\
2.54\end{array}$ & $\begin{array}{l}6.27 \\
4.80\end{array}$ & $\begin{array}{l}2.68 \\
2.52\end{array}$ & $\begin{array}{l}5.94 \\
4.22\end{array}$ & 2.45 & 6. & 2. & & 3. & 6. & $\begin{array}{l}3.17 \\
2.68\end{array}$ \\
\hline W2 & .64 & 2.79 & 3.23 & 2.42 & 4.61 & 2.74 & 3. & 2.41 & 3.8 & 2.5 & 4.18 & 2.4 & 4. & $\begin{array}{l}2.07 \\
2.88\end{array}$ & & 2. & $\begin{array}{l}5.19 \\
4.42\end{array}$ & $\begin{array}{l}2.68 \\
2.92\end{array}$ \\
\hline W2 & .22 & $3 \cdot 33$ & 4.07 & 3.10 & 5.14 & 3.35 & 3.97 & 2.95 & 3.87 & 2. & 4. & 2. & 4.82 & 3.13 & 5 & 3. & 4.98 & 3.76 \\
\hline $\begin{array}{l}\text { W2 } \\
\text { W2 }\end{array}$ & $\begin{array}{r}.35 \\
.15\end{array}$ & $\begin{array}{l}2.72 \\
2.31\end{array}$ & 5.06 & 2.67 & 5.30 & 2.87 & & 2.5 & 4.6 & 2. & & 2. & 5 . & 2. & & & 5.61 & 3.01 \\
\hline & 5.50 & 3.00 & $\begin{array}{l}4.77 \\
6.14\end{array}$ & $\begin{array}{l}2.40 \\
3.01\end{array}$ & $\begin{array}{l}4.40 \\
5.58\end{array}$ & $\begin{array}{l}2.41 \\
2.95\end{array}$ & & $\begin{array}{l}1.95 \\
2.41\end{array}$ & $\begin{array}{l}3 . \\
5 .\end{array}$ & $\begin{array}{l}1.98 \\
2.66\end{array}$ & & $\begin{array}{l}2.80 \\
3.04\end{array}$ & & $\begin{array}{l}2.49 \\
2.85\end{array}$ & 9 & $\begin{array}{l}2 . \\
3 .\end{array}$ & $\begin{array}{l}4.04 \\
5.14\end{array}$ & $\begin{array}{l}2.55 \\
3.09\end{array}$ \\
\hline W24C & 5.37 & & 5.36 & 3.07 & & 3.29 & 4.77 & 2.93 & 4.72 & 2.58 & & 2.06 & & 3.06 & & 3. & & 3.18 \\
\hline W24 & .92 & 2.97 & 4.78 & 3.09 & 5.10 & 3.14 & 4.28 & 2.86 & 4.41 & 2.62 & 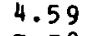 & 2.84 & 4.85 & 3.03 & & & & 3.23 \\
\hline W24C & 6.16 & 3. & 6.07 & 5.43 & 6.44 & 3.70 & 5.79 & 3.52 & 4.20 & 3.02 & 7. & 5.29 & 5. & 3.4 & 6. & 3. & 5.78 & 3.53 \\
\hline & 5.66 & 3. & 5.80 & 3.10 & 5.47 & 3.25 & 5. & 3.20 & 3. & 2. & 3. & 3. & & 3. & & & & 3.34 \\
\hline W24 & 5.12 & & 5.15 & 3.23 & 5.4 & 3.08 & 4. & 2.73 & 4. & 2.55 & 4.97 & 2.57 & 5.19 & 2.9 & 6.30 & 3. & 5.22 & 2.94 \\
\hline & 3.99 & 3.33 & 4.22 & 3.59 & 4. & 3.20 & 3. & 2.92 & 2.80 & 2. & 0.00 & 0. & 3.62 & 2.87 & & & 3.6 & 3.25 \\
\hline & 6.04 & & 6.49 & 4.23 & & 3.26 & & 2.97 & 4. & 2. & 3.10 & 0.00 & 5.71 & 3.2 & 5. & 3. & 5. & 3.20 \\
\hline & $\begin{array}{r}5.23 \\
7.89\end{array}$ & 3.41 & 5,08 & 3.63 & & 3.37 & 4. & 3.15 & 4.30 & 2.78 & & 1.62 & & 3. & & & & 3.2 \\
\hline & $\begin{array}{r}7.89 \\
5.83\end{array}$ & 3. & 7.25 & & & 3.78 & 7. & 3.80 & 5.53 & 3.37 & 8.3 & 3.21 & 6. & 3. & 7.47 & 3. & 6.2 & 3.14 \\
\hline & 5.1 & 3. & 5.19 & 2.8 & 5.18 & & 5. & & 4. & 2.61 & 0. & & & & & & & 3.14 \\
\hline & & & & 3.24 & 4.54 & & & & 3.04 & & & & & & & & J. & 2.73 \\
\hline W2 4 & 3.8 & 2.70 & 3.08 & 1.35 & 3.95 & 2.50 & 3. & 2.50 & 3.04 & & & & & & & & 4. & 2.7 \\
\hline & & 2.57 & 5,00 & 3.2 & & & & 210 & & 206 & & & & & & 4 & 4.8 & 2.5 \\
\hline W9305 & 4.2 & 3.03 & 4.56 & 3.35 & 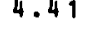 & 3.45 & 3.4 & 2.67 & 3.04 & 2.31 & 3.67 & 2.97 & 4.15 & 2.96 & 5.07 & 3.77 & 4.25 & 3.22 \\
\hline
\end{tabular}


TABLE 7. Average 12-Hour Mean Wind Speed (m/s) and Its Standard Deviation (m/s) for 12-Hour Period Centered on Map Time by Weather Pattern Type

\begin{tabular}{|c|c|c|c|c|c|c|c|c|c|c|c|c|c|c|c|c|c|c|c|}
\hline & STATION & --- & -- & -- & -- & -- & -- & $\cdots$ & -- & ---5 & -- & $\cdots$ & $\cdots$ & $\cdots$ & $\ldots$ & $\ldots$ & - &.- & \\
\hline & $W 1390264$ & 4.72 & 1.97 & 4.75 & 1.96 & 4.94 & 2.21 & 4.02 & 1.7 & 4.18 & 1.7 & 4.01 & 1.5 & 4.70 & 1.91 & 5.18 & 2.05 & 4.87 & 2.29 \\
\hline & W1396064 & 5.77 & 1.95 & 5.44 & 1.96 & 5.24 & 1.98 & 4.66 & 1.86 & 5.00 & 1.78 & 5.11 & 1.55 & 5.34 & 1.77 & 5.94 & 1.82 & 5.46 & 2.09 \\
\hline & $\$ 1396764$ & 6.51 & 2.03 & 6.32 & 2.11 & 6.26 & 2.31 & 5.49 & 1.90 & 5.69 & 1.77 & 5.89 & 1.56 & 6.11 & 1.85 & 6.70 & 2.31 & 6.28 & 2.41 \\
\hline & $W 1396860$ & 4.89 & 1.94 & 4.92 & 1.76 & 5.15 & 2.16 & 4.42 & 1.87 & 4.10 & 1.56 & 4.01 & 1.39 & 4.50 & 1.63 & 5.04 & 1.98 & 4.96 & 2.27 \\
\hline & 6864 & 5.63 & 2.02 & 5.44 & 1.87 & 5.13 & 1.62 & 4.71 & 1.72 & 4.98 & 1.69 & 4.96 & 1.43 & 5.05 & 1.76 & 5.97 & 1.79 & 5.44 & 1.92 \\
\hline & $W 1399664$ & 6.01 & 2.37 & 6.18 & 2.13 & 5.74 & 2.04 & 4.96 & 1.80 & 5.26 & 1.94 & 5.66 & 1.93 & 5.59 & 2.07 & 6.33 & 2.16 & 5.57 & 2.27 \\
\hline & $W 1492264$ & 4.90 & 2.04 & 5.26 & 1.94 & 5.27 & 2.02 & 4.33 & 1.75 & 4.35 & 1.69 & 4.29 & 1.60 & 4.91 & 1.87 & 5.29 & 2.06 & 5.04 & 2.22 \\
\hline & 41493361 & 5.51 & 1.91 & 6.06 & 2.13 & 6.21 & 2.19 & 4.93 & 1.87 & 4.92 & 1.58 & 5.03 & 1.66 & 5.14 & 1.84 & 6.29 & 2.38 & 5.84 & 2.36 \\
\hline & $W 1493364$ & 5.19 & 2.23 & 4.61 & 1.93 & 4.85 & 1.93 & 4.29 & 1.73 & 4.39 & 1.57 & 4.43 & 1.66 & 4.31 & 1.70 & 5.45 & 2.34 & 4.83 & 1.88 \\
\hline & $W 1493561$ & 6.15 & 2.16 & 6.53 & 1.98 & 5.93 & 2.05 & 5.18 & 1.84 & 5.50 & 1.90 & 5.92 & 1.64 & 5.86 & 2.14 & 6.78 & 2.34 & 5.98 & 2.26 \\
\hline & W1493564 & 5.65 & 2.08 & 5.51 & 1.99 & 5.31 & 1.85 & 4.83 & 1.95 & 5.00 & 1.77 & 5.06 & 1.74 & 5.34 & 2.00 & 5.93 & 2.49 & 5.51 & 2.33 \\
\hline & $W 1494064$ & 5.70 & 2.01 & 6.13 & 2.28 & 5.94 & 2.07 & 5.17 & 1.95 & 5.13 & 1.85 & 5.23 & 1.60 & 5.39 & 2.01 & 6.72 & 2.50 & 5.91 & 2.42 \\
\hline & W1494461 & 5.00 & 1.86 & 5.58 & 2.29 & 5.39 & 2.09 & 4.59 & 1.99 & 4.65 & 1.83 & 5.38 & 1.61 & 4.93 & 1.91 & 6.08 & 2.28 & 5.36 & 2.67 \\
\hline & W2302359 & 4.75 & 1.36 & 4.65 & 1.31 & 5.20 & 1.54 & 4.24 & 1.29 & 4.49 & 1.32 & 4.46 & 1.17 & 4.79 & 1.34 & 5.34 & 1.98 & 4.64 & 1.39 \\
\hline & $w 2302364$ & 5.34 & 1.64 & 5.29 & 1.59 & 5.48 & 1.80 & 4.84 & 1.56 & 4.97 & 1.55 & 5.05 & 1.37 & 5.58 & 1.68 & 5.71 & 1.83 & 5.12 & 1.69 \\
\hline & W2304761 & 5.89 & 2.02 & 5.42 & 1.44 & 5.69 & 1.95 & 5.17 & 2.08 & 5.32 & 1.82 & 5.09 & 1.61 & 5.61 & 1.72 & 31 & 2.26 & 5.62 & 2.34 \\
\hline & $w 2304764$ & 6.45 & 1.99 & 5.52 & 2.18 & 6.47 & 2.31 & 5.85 & 2.07. & 6.30 & 1.96 & 6.12 & 1.71 & 6.52 & 2.03 & 7.80 & 2.56 & 6.55 & 2.44 \\
\hline & W2304859 & 5.94 & 1.74 & 5.67 & 1.96 & 5.90 & 1.91 & 5.12 & 1.52 & 5.24 & 1.52 & 5.09 & 1.31 & 5.62 & 1.49 & 5.86 & 1.74 & 5.58 & 1.76 \\
\hline & W2304864 & 5.13 & 1.57 & 4.06 & 1.46 & 5.01 & 1.68 & 4.41 & 1.49 & 4.57 & 1.53 & 4.80 & 1.35 & 4.98 & 1.71 & 5.54 & 1.81 & 4.79 & 1.85 \\
\hline & W2305264 & 4.51 & 2.22 & 4.38 & 2.06 & 4.73 & 2.37 & 3.82 & 2.09 & 3.68 & 1.89 & 3.74 & 1.7 & 4.33 & 1.99 & 5.22 & 2.78 & 4.66 & 2.75 \\
\hline & $W 2306260$ & 5.12 & 1.72 & 5.40 & 1.84 & 5.23 & 1.82 & 4.92 & 1.58 & 4.54 & 1.52 & 4.86 & 1.62 & 4.82 & 1.55 & 5.34 & 2.11 & 5.23 & 1.97 \\
\hline & W2306264 & 4.29 & 1.40 & 4.32 & 1.27 & 4.26 & 1.46 & 4.01 & 1.12 & 3.74 & 1.14 & 5.12 & 2.10 & 4.20 & 1.44 & 4.61 & 1.68 & 4.12 & 1.55 \\
\hline & $W 2306564$ & 5.88 & 2.13 & 6.44 & 2.33 & 5.91 & 2.20 & 5.13 & 1.79 & 5.56 & 1.95 & 5.76 & 2.28 & 5.70 & 2.03 & 6.56 & 2.63 & 5.65 & 2.38 \\
\hline & $W 2401161$ & 5.39 & 2.17 & 5.63 & 2.38 & 5.79 & 2.44 & 4.87 & 2.17 & 4.77 & 1.94 & 4.90 & 1.77 & 5.49 & 2.29 & 6.53 & 2.66 & 5.45 & 2.49 \\
\hline & $W 2402364$ & 5.23 & 2.10 & 5.29 & 2.15 & 5.30 & 2.26 & 4.52 & 2.01 & 4.68 & 1.89 & 5.20 & 2.07 & 5.09 & 2.15 & 6.29 & 3.02 & 5.22 & 2.39 \\
\hline & $W 2402760$ & 6.06 & 2.58 & 6.20 & 3.74 & 6.48 & 2.78 & 6.02 & 2.71 & 4.68 & 2.00 & 7.01 & 3.87 & 5.96 & 2.46 & 6.54 & 2.66 & 5.93 & 2.62 \\
\hline & $\$ 2402764$ & 5.70 & 1.98 & 6.01 & 2.08 & 5.66 & 2.01 & 5.42 & 2.25 & 4.49 & 1.79 & 4.36 & 1.92 & 5.57 & 2.10 & 6.27 & 2.10 & 5.48 & 2.35 \\
\hline & $W 2402864$ & 5.37 & 2.25 & & 2.16 & 5.64 & 2.22 & 5.09 & 2.00 & 5.01 & 1.79 & 5.31 & 1.79 & 5.41 & 2.01 & 6.44 & 2.76 & 5.59 & 2.16 \\
\hline & W2402964 & 4.46 & 2.17 & 4.68 & 2.31 & 4.66 & 2.28 & 4.04 & 2.03 & 3.41 & 1.70 & 0.00 & 0.00 & 4.08 & 1.97 & 5.31 & 2.52 & 4.17 & 2.35 \\
\hline & $W 2408964$ & 6.22 & 2.14 & 6.36 & 2.88 & 6.03 & 2.30 & 6.01 & 2.34 & 5.11 & 2.01 & 5.50 & 0.00 & 5.85 & 2.28 & 6.07 & 2.16 & 5.92 & 2.38 \\
\hline & W2409064 & 5.41 & 2.47 & 5.35 & 2.56 & 5.71 & 2.53 & 4.89 & 2.42 & 4.57 & 2.03 & 4.08 & 1.32 & 5.06 & 2.20 & 6.32 & 2.89 & 5.28 & 2.56 \\
\hline & $W 2414359$ & 7.81 & 3.10 & 7.72 & 3.57 & 6.48 & 2.90 & 7.80 & 3.42 & 5.58 & 2.90 & 8.89 & 3.63 & 6.36 & 3.08 & 7.35 & 3.03 & 6.30 & 2.84 \\
\hline & W2414364 & 5.91 & 2.44 & 5.36 & 2.39 & 5.38 & 2.21 & 5.84 & 2.59 & 4.58 & 2.10 & 0.00 & 0.00 & 5.10 & 2.44 & 6.09 & 2.49 & 5.52 & 2.73 \\
\hline & W2414461 & 4.10 & 2.06 & 3.70 & 2.02 & 4.40 & 1.98 & 3.78 & 1.81 & 3.01 & 1.49 & 4.79 & 2.63 & 3.73 & 1.84 & 4.82 & 2.06 & 3.72 & 1.78 \\
\hline & $W 2414464$ & 4.07 & 2.04 & 3.22 & 0.97 & 4.16 & 1.75 & 3.68 & 1.72 & 3.24 & 1.34 & 0.00 & 0.00 & 3.75 & 1.75 & 4.43 & 1.85 & 4.17 & 1.95 \\
\hline & W9303764 & 4.97 & 1.61 & 5.06 & 2.17 & 5.04 & 1.98 & 4.29 & 1.38 & 4.11 & 1.34 & 4.65 & 1.39 & 4.69 & 1.61 & 5.63 & 2.41 & 4.69 & 1.83 \\
\hline & W9305862 & 4.17 & 1.93 & 4.18 & 2.29 & 4.46 & 2.51 & 3.43 & 1.92 & 3.14 & 1.51 & 3.76 & 1.77 & 3.96 & 1.85 & 4.79 & 2.93 & 4.19 & 2.31 \\
\hline
\end{tabular}


TABLE 8. Mean U-Component $(\mathrm{m} / \mathrm{s})$ and Its Standard Deviation $(\mathrm{m} / \mathrm{s})$ by Weather Pattern Type; $U>0$ From the East

\begin{tabular}{|c|c|c|c|c|c|c|c|c|c|c|c|c|c|c|c|c|c|c|}
\hline STATION & -- & -- & - & -- & -- & - & - & -- & - & & & & & & $\cdots$ & & $=-$ & \\
\hline 139026 & 0.73 & 2.08 & 0.85 & 2.4 & 023 & 2.54 & & 1.98 & 1.2 & 1.76 & 0.96 & & & 2.18 & 0.02 & & 0.01 & 2.0 \\
\hline & & 0 & 0.5 & 2.49 & & 2.57 & 0.41 & 2.1 & 1.10 & 1.94 & 0.50 & 1.6 & 1.04 & & -0.28 & & 0.08 & $\begin{array}{l}2.04 \\
2.90\end{array}$ \\
\hline & & 2.3 & 1.04 & 2.64 & 0.23 & 2.90 & 0.17 & 2.3 & 1.02 & 2.07 & 0.77 & & 0.91 & & -0.50 & 3. & -0.41 & 2.91 \\
\hline$W 139$ & 0.19 & 1.82 & 0.45 & 2.38 & -0.13 & 2.47 & 0.05 & 1.83 & 0.90 & 1.54 & 0.68 & 1.03 & 0.64 & 1.87 & -0.04 & 2.75 & -0.36 & 2.46 \\
\hline & 0.55 & 1.96 & 1.24 & 2.32 & -0.93 & 2.45 & -0.23 & 2.0 & 0.81 & 1.8 & 0.62 & 1. & 0.93 & 1.97 & -0.96 & & & 3.00 \\
\hline & & 2.73 & 1.27 & 3.45 & & 3.26 & -0.81 & 2.9 & 1.03 & 2.82 & 0.21 & 2. & 0.86 & 3.04 & -0.56 & 4.07 & & 3.70 \\
\hline & 1.01 & 2.81 & 0.39 & 3.15 & -2. & 3.24 & -1.10 & 2.67 & 0.59 & 2.66 & 0.69 & 1. & 0.52 & 3.05 & -1.64 & 3.26 & -1.20 & 3.45 \\
\hline & -1 . & 2.73 & -0.12 & 3.75 & -1.96 & 3.81 & -1.00 & 3.05 & 0.38 & 2.94 & -0.21 & 2. & 0 & 3.17 & -1.84 & & -1 & 3.85 \\
\hline & & 2.96 & 0.18 & 2.80 & -1.39 & 2.81 & -0.98 & 2.6 & 0.54 & 2.5 & 0.00 & 2. & 0.22 & 2.56 & -0.83 & 3.79 & -1.36 & 3.09 \\
\hline $\begin{array}{l}w_{1} \\
w_{1}\end{array}$ & $\begin{array}{l}-0.4 \\
-0.4\end{array}$ & $\begin{array}{l}2.78 \\
2.42\end{array}$ & $\begin{array}{r}-0.26 \\
0.60\end{array}$ & $\begin{array}{l}3.45 \\
2.89\end{array}$ & $\begin{array}{l}-0.59 \\
-0.90\end{array}$ & 3.25 & $\begin{array}{l}-1 \cdot 15 \\
-1.23\end{array}$ & 2.87 & 0.29 & 2.89 & 0.21 & 2. & 0.56 & 3.12 & -0 & 3. & -0.81 & .31 \\
\hline Wi & & 3.22 & 0.03 & 3.74 & -2.49 & 3. & $\begin{array}{l}-1 . \\
-1 .\end{array}$ & 2. & $\begin{array}{l}0.60 \\
0.43\end{array}$ & $\begin{array}{l}2.4 \\
3.1\end{array}$ & $\begin{array}{r}0.65 \\
-0.22\end{array}$ & 1. & $\begin{array}{l}0.71 \\
0.28\end{array}$ & $\begin{array}{l}2.59 \\
3.33\end{array}$ & -1 & $\begin{array}{l}3.22 \\
4.24\end{array}$ & $-1 \cdot 38$ & .02 \\
\hline W14 & -0 . & 2.49 & 0.10 & 3.3 & -1.60 & & -1 & & 1. & & 2.01 & 2. & 0.77 & & $\begin{array}{l}-1 \\
-1\end{array}$ & $\begin{array}{l}4.24 \\
3.80\end{array}$ & $\begin{array}{l}-1 \\
-1\end{array}$ & $\begin{array}{l}.94 \\
.68\end{array}$ \\
\hline & 0 . & 2.72 & 0.30 & 3.0 & 0. & 3. & -0 & 2.8 & 1. & 2.6 & 1.63 & 2. & 1.18 & 2. & -1 & 3 & & .96 \\
\hline $\begin{array}{l}W 23 \\
W 23\end{array}$ & -0. & 2.91 & -0.32 & 3.26 & -0 . & 3. & -0.10 & 2.7 & 1.01 & 2.6 & 1.30 & 2.2 & 0.79 & 3. & -0 & 3. & -0.30 & 3.30 \\
\hline $\begin{array}{l}\text { W2 } \\
\text { W2 }\end{array}$ & $\begin{array}{l}-1 . \\
-1 .\end{array}$ & 2.93 & $\begin{array}{r}0.30 \\
-0.10\end{array}$ & 2.77 & -0.48 & 3.1 & -1.08 & 2.8 & -0.12 & 2.8 & -0.40 & 2. & & 9 & -0 & 2 & 30 & \\
\hline & $\begin{array}{l}-1 \\
-2\end{array}$ & $\begin{array}{l}2.93 \\
3.27\end{array}$ & $\begin{array}{l}-0.10 \\
-2.06\end{array}$ & $\begin{array}{l}2.35 \\
3.64\end{array}$ & $\begin{array}{l}-0 . \\
-0 .\end{array}$ & $\begin{array}{l}3.74 \\
4.38\end{array}$ & $\begin{array}{l}-1.02 \\
-1.94\end{array}$ & $\begin{array}{l}3.01 \\
3.10\end{array}$ & $\begin{array}{l}-0 . \\
-1 .\end{array}$ & $\begin{array}{l}2.9 \\
3.1\end{array}$ & $\begin{array}{l}-1.22 \\
-1.65\end{array}$ & 2. & 0. & 3 . & $\begin{array}{l}-1 \\
-1\end{array}$ & 4. & $\begin{array}{l}-1 \\
-1\end{array}$ & $\begin{array}{l}35 \\
.22\end{array}$ \\
\hline 14230 & -2.09 & 2.76 & -0.59 & 3.11 & -0. & 3. & -1.39 & .2 .5 & -0.92 & 2.8 & -1.71 & 2.06 & -0 & & -1 & 3. & -1.42 & 2.95 \\
\hline & -0 & 2.37 & -0.13 & 1.76 & -0 . & 2.44 & -0.25 & 1.7 & -0. & 1.6 & 0.06 & 1.62 & -0 & 2. & -1 & 2. & -0.26 & 2.00 \\
\hline W2 & 0 & 2.0 & -0.62 & 2.37 & -0 & 2.72 & -0 & 2.10 & -0 & 1 & -0.77 & 2.5 & 0.03 & 2.02 & -0 & 2.61 & -0.46 & 2.44 \\
\hline 2 & -0 & 1.9 & 0.29 & 1.9 & -0.05 & 2.19 & -0.26 & 1.68 & -0 & 1. & -1.88 & 3. & & 1.90 & -0 & 1.93 & -0 & 1.89 \\
\hline 2 & 0 & 2.6 & -0. & 3. & & & & & -0 . & 2 & -0.28 & 2.3 & 0.28 & 2. & -0.51 & 3.52 & -0.92 & 2.87 \\
\hline & -0 & 3.51 & -0.09 & 4.09 & -1.86 & 4.07 & -1.56 & 3.31 & 1.31 & 3. & -1.29 & 2.4 & 0.99 & 3. & & 4 & -1.15 & 4.03 \\
\hline W2 & & 2.1 & 0.17 & 2.73 & -0 & 2.76 & & 2.33 & 0.90 & 2.3 & 1.15 & 2.00 & 0.79 & 2.48 & -0.79 & 3.41 & -0.49 & 2.77 \\
\hline & -3 & 3.46 & -3.83 & 4.42 & $-3 \cdot 7$ & 4.5 & -4. & 3.83 & -1.31 & 3.1 & -4.62 & 5,4 & -2.37 & 4.20 & & & -2.56 & 4.42 \\
\hline W 24 & -2 & 3.16 & $-4 \cdot 34$ & 3.96 & & 3.92 & -3. & & -1.08 & 3.0 & -2.48 & 2.85 & -1.92 & 3.68 & -3.29 & 4.06 & -2.81 & 3.56 \\
\hline & & 3.6 & $\begin{array}{r}0.10 \\
-1.21\end{array}$ & 4.48 & -0.89 & 3.96 & -1.67 & $3 \cdot 3$ & 1.24 & 3.4 & -0.27 & 4.06 & 0.52 & 3.73 & -1.65 & 4.52 & -1.18 & 3.94 \\
\hline $\begin{array}{ll}W 2 \\
w 2\end{array}$ & -1 & 2.61 & -1.21 & & & 2. & & 2.4 & -0. & 2.2 & 0.00 & 0.00 & -1.55 & 2.50 & -2.72 & 3.16 & -1.75 & 2.65 \\
\hline W2 & & 2.93 & $-3 \cdot 3$ & 3.10 & -2.28 & 3.6 & -3.24 & 2.97 & -1.45 & 3.3 & -2.90 & 0.0 & -2.32 & 342 & -2.10 & 3.70 & -2.81 & 3.21 \\
\hline W24 & -0 & 2.59 & -0.27 & & -1. & 2.6 & -1 . & & & & 0.03 & 2.5 & 0.03 & 2.52 & -1.50 & 3.09 & -0.81 & 2.61 \\
\hline W24 & & & -4.91 & 3.70 & -3.29 & 3. & -4.87 & 3.7 & -1.68 & 3.7 & -6.59 & & -2.60 & 3.88 & -4.27 & 4.06 & & . 32 \\
\hline W22 & -3 & & -2.21 & 2.76 & -2.72 & 3.18 & & & & & 0.00 & 0.0 & -2.19 & 3.12 & -3.42 & 3.34 & -2.71 & 2.99 \\
\hline & & & -2.14 & 1.98 & -2.7 & 2.35 & -2.35 & 2.1 & -1.07 & 1.5 & -3.26 & 3.0 & -1.87 & & & 2.42 & & \\
\hline & -2 & & -1 . & 1. & -2 & 2. & -2.1 & . & -1.28 & 1. & 0.00 & & & & & & -2 & \\
\hline $\begin{array}{r}W 930376 \\
W 930586\end{array}$ & & & & & & & 0 & 1.79 & 0 & 1.5 & 1.01 & $c \cdot 20$ & & 1.69 & 0.21 & 2.95 & 0.10 & .68 \\
\hline W9 30586 & -0.63 & 2.54 & 0.23 & 2.30 & 0.06 & 3.08 & -0.44 & 2.32 & 0.30 & 2.09 & -0.51 & 2.29 & 0.51 & 2.59 & -0.08 & 3.13 & -0.20 & 2.60 \\
\hline
\end{tabular}


TABLE 9. Mean U-Component $(\mathrm{m} / \mathrm{s})$ and Its Standard Deviation $(\mathrm{m} / \mathrm{s})$ by Weather Pattern Type; $U>0$ From the North

\begin{tabular}{|c|c|c|c|c|c|c|c|c|c|c|c|c|c|c|c|c|c|c|}
\hline ION & -1 & -- & -- & --- & $=-$ & -- & -- & & $\ldots$ & & -- & & $5-5$ & & -- & & & \\
\hline 26 & -1.6 & 6 & 0.7 & 3.65 & & 5 & & 3.1 & & 3.26 & & & & & & & & \\
\hline & & & & & & & & & & & & & & & & & & \\
\hline & & 4 & 2. & & & 4. & & 4. & -2.82 & 4.1 & -7. & & & & & & & \\
\hline & -2 & 3.1 & -0. & & 2. & 3. & & & 169 & & -3.0 & 2. & -1 & 3.0 & 0.87 & 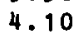 & 0.45 & 4 \\
\hline & & 3.9 & -2 & 3.4 & & 3. & & & -2 & & & & & & 0. & & & \\
\hline & & is & & & 2. & 3. & & 3. & -2.24 & 3. & -4.11 & 3.06 & -0.98 & & 1. & 4. & 0.58 & 3. \\
\hline & 1 & $3 \cdot 3$ & -1 & 3.5 & & 3. & & & -2.09 & & -2.7 & 1. & & & 1. & & & 2 \\
\hline & & 3.8 & -0 . & & 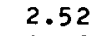 & 3. & & 3. & -2 & & & 2 . & & & & & & \\
\hline & & 3.74 & -1 & 2.9 & 19 & 3. & 1.14 & 2 & -2.0 & & -2 & & -0 . & & 1. & 3. & & 3. \\
\hline & 1 . & $\begin{array}{l}4.6 \\
4.4\end{array}$ & $\begin{array}{l}-1 \\
-2\end{array}$ & 4.7 & & & & & -2.4 & & & 3.7 & -0 . & & 2.30 & 4.7 & 1. & 4. \\
\hline & $\because$ & 3.8 & -1 & & 2. & & 1. & & -2. & & $\begin{array}{l}-1 \\
-3 .\end{array}$ & $\begin{array}{l}4 . \\
3 .\end{array}$ & $\begin{array}{l}-0 . \\
-0 .\end{array}$ & 3. & 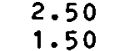 & & & $\begin{array}{l}8 \\
0\end{array}$ \\
\hline & -1 & 3.5 & -1 & 4. & . & 3. & .57 & & & & & & -0 & & & & & \\
\hline & - & 2. & -0 . & 2.8 & 1. & 3. & 0.0 & 3. & -1 . & 2 . & -2 & 2 . & -1 & 2 . & 0 . & & 1. & 2. \\
\hline & & & $\begin{array}{l}-0 \\
-1\end{array}$ & & & & 0 . & & $\begin{array}{l}-1 \\
-1\end{array}$ & & -3 & & -1 & & 1. & & $:$ & $\begin{array}{l}7 \\
3\end{array}$ \\
\hline & -2 & 4.25 & -1. & $\begin{array}{l}3.8 \\
3.2\end{array}$ & $\begin{array}{l}0.0 \\
1.5\end{array}$ & 4. & 0.1 & & $\begin{array}{l}-1 \\
-3 .\end{array}$ & & $\begin{array}{l}-3 . \\
-3 .\end{array}$ & & $\begin{array}{l}-1 \\
-2\end{array}$ & & .0. & & & 4.8 \\
\hline & -1 & 3.2 & -1.1 & 3. & 0.7 & 3. & 0.8 & & -1.8 & 2. & -2 & 2. & -1 & & -0 & 2. & -0 & 3.4 \\
\hline & & 2 & & 2. & & & & & & & & & -1 & & & & & \\
\hline & -0 & 3. & -1 & 3. & 0 . & 3. & & & -0 . & & -0 & & -0 & & 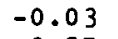 & & & 4. \\
\hline & & 2.9 & & & & & 1 & & -1 & & & & -0 & & & & & \\
\hline & $\begin{array}{l}-0 \\
-1\end{array}$ & 2.4 & -0 & 2. & 0. & 2. & 1. & 2. & -1 & & -0 & & -0 & & 0. & & & 2 \\
\hline & $\begin{array}{l}-1 . \\
-0 .\end{array}$ & 4.5 & $\begin{array}{l}-1 \\
-0\end{array}$ & 5. & & 4. & 1. & & -2 & & -2 & & & & & & & \\
\hline & -0 . & 4. & $\begin{array}{l}-0 . \\
-0 .\end{array}$ & & & & 1. & & $\begin{array}{l}-1 . \\
-1 .\end{array}$ & & - & $\begin{array}{l}3 . \\
4 .\end{array}$ & $\begin{array}{r}-0 \\
0\end{array}$ & & 1. & & & $\begin{array}{l}3.24 \\
4.20\end{array}$ \\
\hline & -1 & 2.5 & -1 & 2.0 & 0. & 2.2 & 1.2 & & -0. & & -1 & 2. & -1 & & -0 . & & 0 & 2.60 \\
\hline & -1.5 & 2.35 & -0 . & 1. & 1 & & -1.43 & & -1 & & & & -1 & & 0 & & & 2.29 \\
\hline & & 2. & & 3. & 2. & 2. & 1. & 2. & -0 & & 0 . & & 0 & 2 & 2. & 3 & 1. & 2.94 \\
\hline & & 2. & & & & & & & & & & & & & & & & \\
\hline & -1 & & -2 & 3. & 0. & & -1. & & -1 & & -3 & & -1 & & -0. & & -1 & 3.62 \\
\hline & & 4. & & 4. & & & & & & & & & & & & & & 4.00 \\
\hline & -2 & 4. & & & -0 & & -3 & & & & -3 & & -1 & & -0 . & & -1. & 3.76 \\
\hline & -1 & 3. & -2 & & -1 & & -2 & & & & & & & & -1 & & & \\
\hline & & & & & & & & & & & 0. & & & & & & & 58 \\
\hline & 0. & 2. & & & & & & & & & & & & & & & & \\
\hline & 1 & & 1 & & 1. & & 1. & & o. & & & & & & & & & $\cdot 1$ \\
\hline & 0.13 & 2.00 & 0.41 & 13 & 0.12 & & 0.31 & & -0.20 & 1.01 & -0.33 & 1.80 & 0.03 & & 1.16 & 3.46 & 0.69 & 2.1 \\
\hline
\end{tabular}


TABLE 10. Square Root of Mean Squared Speed $(\mathrm{m} / \mathrm{s})$ and Its Standard Deviation (m/s) by Weather Pattern Type

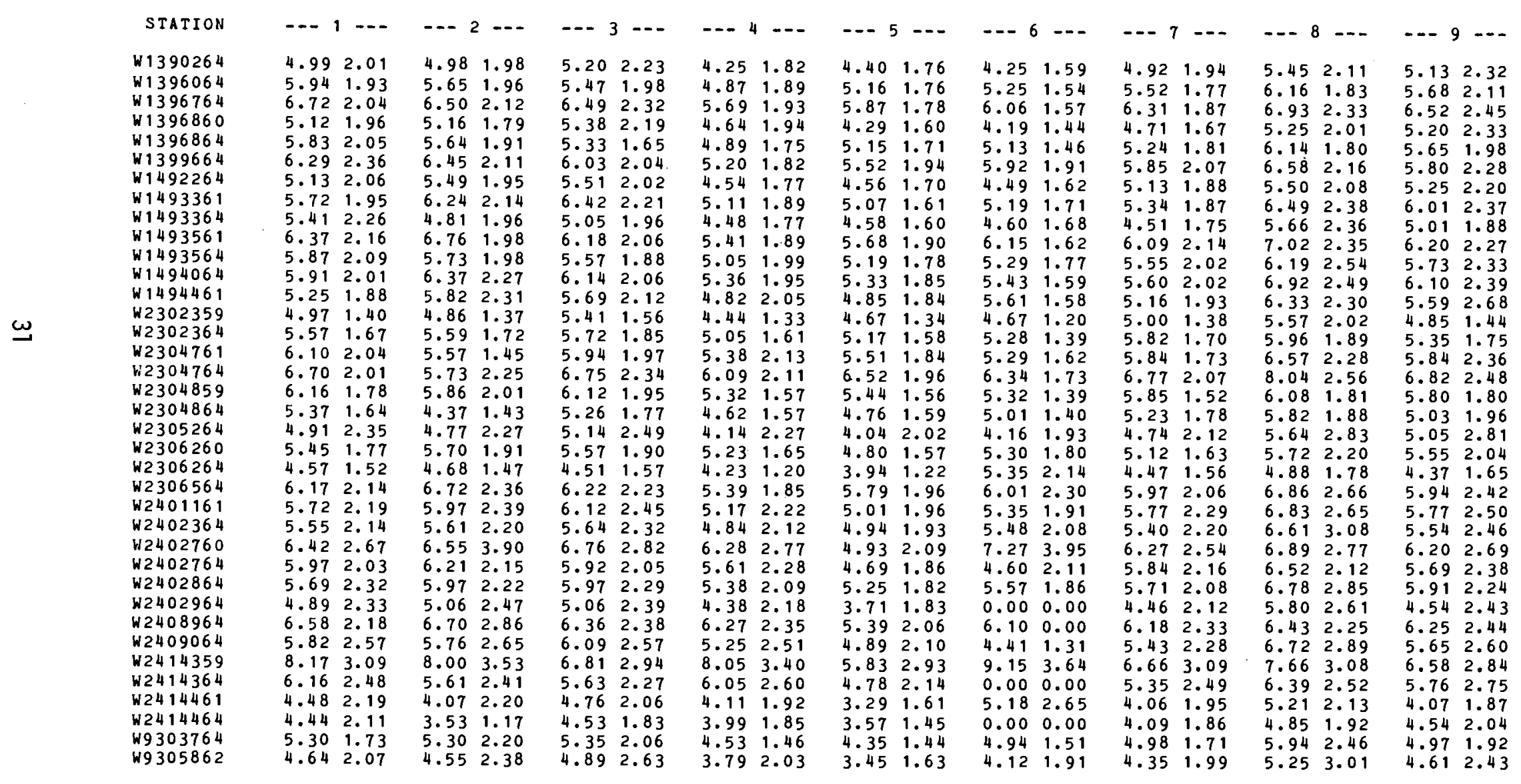


TABLE 11. Cube Root of Mean Cubed Speed (m/s) and Its Standard Deviation (m/s) by Weather Pattern Type

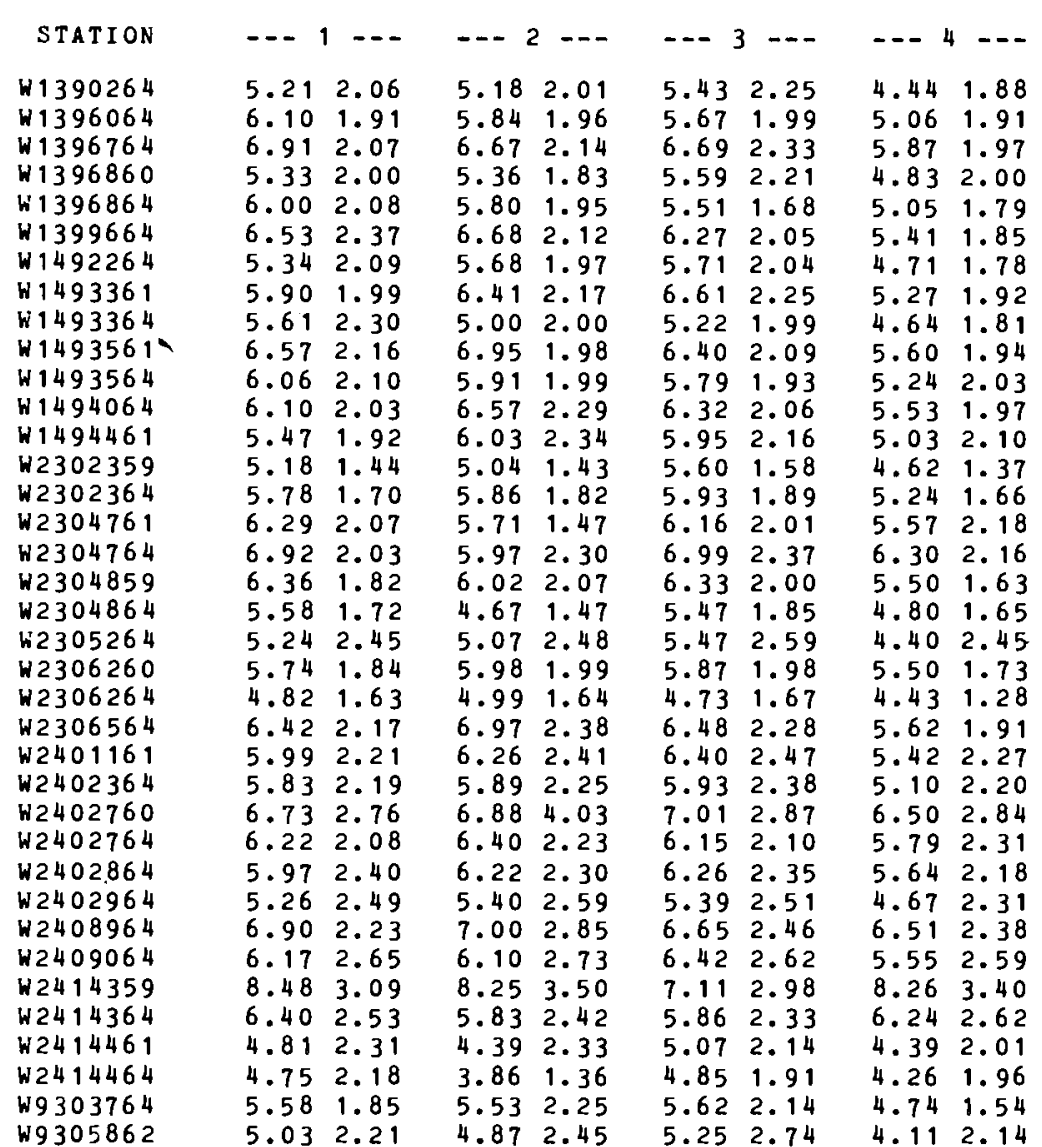

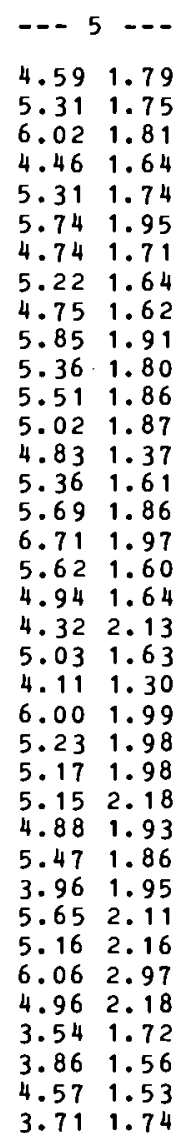

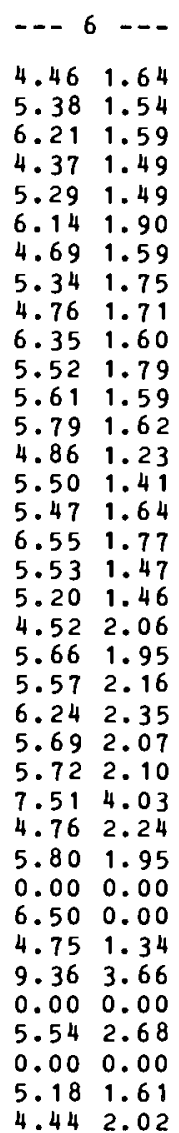

$\begin{array}{ll} \\ -.-7 & -.- \\ 5.12 & 1.97 \\ 5.68 & 1.77 \\ 6.50 & 1.89 \\ 4.91 & 1.70 \\ 5.42 & 1.85 \\ 6.07 & 2.08 \\ 5.32 & 1.89 \\ 5.53 & 1.90 \\ 4.69 & 1.80 \\ 6.29 & 2.16 \\ 5.75 & 2.04 \\ 5.79 & 2.05 \\ 5.37 & 1.95 \\ 5.19 & 1.42 \\ 6.02 & 1.74 \\ 6.04 & 1.76 \\ 7.00 & 2.13 \\ 6.06 & 1.55 \\ 5.45 & 1.86 \\ 5.06 & 2.24 \\ 5.39 & 1.71 \\ 4.70 & 1.68 \\ 6.20 & 2.10 \\ 6.02 & 2.30 \\ 5.68 & 2.26 \\ 6.55 & 2.62 \\ 6.08 & 2.21 \\ 5.97 & 2.14 \\ 4.79 & 2.27 \\ 6.48 & 2.39 \\ 5.75 & 2.35 \\ 6.94 & 3.11 \\ 5.57 & 2.55 \\ 4.35 & 2.06 \\ 4.39 & 1.97 \\ 5.22 & 1.80 \\ 4.68 & 2.12 \\ 5 & \end{array}$

$--8-\cdots$

$\begin{array}{lll}5.68 & 2.17\end{array}$ 6.351 .84 $\begin{array}{lll}7.12 & 2.37\end{array}$ 5.432 .03 6.301 .83 $6.80 \quad 2.17$ $5.68 \quad 2.11$ 6.662 .39 $\begin{array}{ll}6.66 & 2.39 \\ 5.38 & 2.38\end{array}$ $\begin{array}{ll}5.23 & 2.37\end{array}$ $\begin{array}{ll}7.23 & 2.37 \\ 6.38 & 2.58\end{array}$ $\begin{array}{ll}6.38 & 2.58 \\ 7.10 & 2.49\end{array}$ 6.552 .32 $\begin{array}{ll}7.55 & 2.32 \\ 5.77 & 2.07\end{array}$ 6.181 .95 6.78
6.79
8.2 .32 6.79
8.27
6.58 $\begin{array}{ll}6.27 & 2.58 \\ 6.28 & 1.87\end{array}$ 6.051 .96 6.051 .96 5.982 .90 5.03
5.12
7.1287 7.12 2.71 $\begin{array}{ll}7.12 & 2.71 \\ 7.09 & 2.66\end{array}$ 6.893 .14 7.19
6.87 $\begin{array}{ll}7.19 & 2.87 \\ 6.74 & 2.13\end{array}$ 7.072 .94 $6.20 \quad 2.70$ 6.732 .34 $7.06 \quad 2.91$

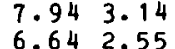
$\begin{array}{ll}6.64 & 2.55 \\ 5.54 & 2.20\end{array}$ 5.221 .99 6.212 .53 5.613 .07
-.- 9 $5.34 \quad 2.35$ 5.872 .14 $6.72 \quad 2.50$ 5.412 .39 5.852 .04 6.012 .29 5.432 .20 6.172 .38 $5.17 \quad 1.87$ 6.402 .29 5.932 .36 5.27
5.792 .38 $\begin{array}{ll}5.79 & 2.70 \\ 5.04 & 1.49\end{array}$ $\begin{array}{ll}5.04 & 1.49 \\ 5.57 & 1.81\end{array}$ $\begin{array}{ll}5.57 & 1.81 \\ 6.04 & 2.38\end{array}$ $\begin{array}{ll}7.06 & 2.53\end{array}$ 7.062 .53
5.991 .85 5.99
5.24
5.32 .05 $\begin{array}{ll}5.24 & 2.05 \\ 5.36 & 2.88\end{array}$ $\begin{array}{ll}5.36 & 2.88 \\ 5.83 & 2.12\end{array}$ 5.83
4.601 .75 4.601 .75
6.192 .46 6.192 .46
6.042 .51 6.042 .51 5.812 .53 6.452 .76
5.89 5.892 .40 $\begin{array}{lll}6.18 & 2.33\end{array}$ $\begin{array}{ll}4.86 & 2.52 \\ 6.53 & 2.49\end{array}$ 5.962 .64 6.832 .86 5.972 .77 4.371 .96 4.852 .12 5.202 .00 $4.96 \quad 2.53$ 
TABLE 12. Mean 12-Hour Maximum Wind Speed $(\mathrm{m} / \mathrm{s})$ and Its Standard Deviation (m/s) by Weather Pattern Type

\begin{tabular}{|c|c|c|c|c|c|c|c|c|}
\hline STATION & \multicolumn{2}{|c|}{$---1 \quad---$} & \multicolumn{2}{|c|}{$\cdots-2 \ldots$} & \multicolumn{2}{|c|}{$--3 \ldots$} & \multicolumn{2}{|c|}{$\ldots 4 \ldots$} \\
\hline$W 1390264$ & 7.19 & 2.75 & 7.04 & 2.61 & 7.43 & 2.90 & 6.12 & 2.54 \\
\hline W1396064 & 8.05 & 2.28 & & 2.44 & 7.68 & 2.39 & 6.91 & 2.40 \\
\hline 764 & & 2.75 & 8.81 & 2.80 & 8.91 & 2. & 7.85 & 2.61 \\
\hline W1396860 & 7.37 & 2.77 & 7.30 & 2.51 & 7.62 & 2.89 & 6.62 & 2.74 \\
\hline W1396864 & 8.02 & 2.65 & 7.83 & 2.71 & 7.43 & 2.27 & 6.87 & 2.36 \\
\hline W1399664 & & 2.99 & 8.97 & 2.66 & 8.58 & 2.59 & 7.45 & 2.41 \\
\hline W1492264 & 7.33 & 2.79 & 7.70 & 2.55 & 7.69 & 2.50 & 6.42 & 2.23 \\
\hline$W 1493361$ & 8.01 & 2.71 & 8.52 & 2.75 & & 2.79 & 7.07 & 2.45 \\
\hline W1493364 & 7.62 & 2.94 & 6.87 & 2.78 & 6.98 & 2.56 & 6.28 & 2.33 \\
\hline$W 1493561$ & 8.80 & 2.73 & 9.21 & 2.46 & 8.67 & 2.65 & 7.60 & 2.62 \\
\hline W1493564 & 8.16 & 2.58 & 7.84 & 2.40 & 7.99 & 2.56 & 7.19 & 2.66 \\
\hline 11. & 8.13 & 2.61 & 8.74 & 2.92 & & 2.5 & 7.33 & 2.47 \\
\hline W1494461 & 7.61 & 2.60 & .19 & 3.02 & 8.29 & 2.8 & 6.95 & 2.76 \\
\hline W2302359 & 7.25 & 2.12 & 6.87 & 2.15 & 7.65 & 2.12 & 6.43 & 2.00 \\
\hline W2302364 & 8.02 & 2.31 & 8.32 & 2.53 & 8.18 & 2.58 & 7.26 & 2.33 \\
\hline$w 2304761$ & 8.49 & 2.73 & 7.38 & 1.8 & 8.52 & 2. & & 2.95 \\
\hline W2304764 & 9.43 & 2.67 & 8.23 & 3.23 & 9.52 & 2.8 & 8.62 & 2.79 \\
\hline W2304859 & 8.53 & 2.48 & 8.09 & 2. & 8.52 & 2. & & 2.33 \\
\hline H2304864 & 7.69 & 2.57 & 7.04 & 2.44 & 7.52 & 2.6 & 6.61 & 2.46 \\
\hline W230s & 7.44 & 3.45 & 7.06 & 3.74 & 78 & 3.60 & .13 & 3.56 \\
\hline W2306260 & 8.33 & 2.65 & 8.56 & 3.03 & 8.55 & 2.98 & 7.91 & 2.66 \\
\hline W2306264 & 7.06 & 2.63 & 7.55 & 2.82 & 6.76 & 2.53 & 33 & 2.08 \\
\hline W2306564 & 8.90 & 2.88 & 9.52 & 3.11 & 8.96 & 3.04 & 7.84 & 2.67 \\
\hline W2401 & & 2.79 & 8.77 & 3.05 & 8.93 & 3. & 7.57 & 2.89 \\
\hline W2402364 & 8.33 & 2.97 & 8.39 & 3.08 & 8.41 & 3.25 & 7.35 & 3.06 \\
\hline W2402760 & & 3.88 & & 5.56 & 9.64 & 3.76 & 8.86 & 3.79 \\
\hline W2402764 & & 2.91 & & 3.11 & 8.40 & 2.73 & 7.76 & 3.04 \\
\hline W2402864 & 8. & 3.37 & & 3.30 & 8.89 & 3.2 & 8.01 & 3.13 \\
\hline H2402964 & 7.99 & 3.89 & 7.89 & 3.63 & 7.93 & 3.58 & 6.85 & 3.44 \\
\hline W2408964 & & 3.17 & & 3.57 & 9.41 & 3.43 & & 3.09 \\
\hline W2409 & 2 & 3.61 & & 3.80 & 9.14 & 3.40 & 7.98 & 3.44 \\
\hline W2414359 & 11.67 & 3.96 & 11.02 & 4.20 & 9.93 & 3.86 & 10.82 & 4.01 \\
\hline W24 & 8.8 & 3.35 & 8.10 & 2.95 & 8.13 & 3.15 & 8.40 & 3.26 \\
\hline W2414461 & 7.41 & 3.58 & 6.82 & 3.69 & 7.57 & 3.12 & 6.58 & 2.93 \\
\hline W24 & 7.19 & 3.05 & 6.34 & 2.61 & 7.33 & 2.76 & 6.43 & 2.99 \\
\hline W9 & 8.1 & 2.92 & & 2.88 & & 3.03 & 6.78 & 2.37 \\
\hline W9 305862 & & & 2 & 3.30 & 7.88 & 3.94 & 6.30 & 3.16 \\
\hline
\end{tabular}

$\begin{array}{ll}6.31 & 2.39 \\ 7.10 & 2.06 \\ 8.00 & 2.43 \\ 6.16 & 2.27 \\ 7.22 & 2.32 \\ 7.88 & 2.51 \\ 6.49 & 2.19 \\ 7.01 & 2.21 \\ 6.51 & 2.14 \\ 7.80 & 2.43 \\ 7.28 & 2.29 \\ 7.40 & 2.36 \\ 6.86 & 2.46 \\ 6.62 & 1.92 \\ 7.38 & 2.19 \\ 7.66 & 2.46 \\ 9.04 & 2.47 \\ 7.52 & 2.22 \\ 6.69 & 2.38 \\ 6.21 & 3.05 \\ 7.16 & 2.38 \\ 5.85 & 2.11 \\ 8.15 & 2.60 \\ 7.28 & 2.58 \\ 7.30 & 2.71 \\ 7.28 & 3.22 \\ 6.74 & 2.77 \\ 7.59 & 2.61 \\ 5.88 & 3.01 \\ 8.03 & 2.95 \\ 7.42 & 2.97 \\ 8.40 & 3.86 \\ 6.86 & 2.94 \\ 5.44 & 2.71 \\ 6.02 & 2.55 \\ 6.55 & 2.38 \\ 5.65 & 2.67 \\ 6 & \end{array}$

$---6 \quad--$

$\begin{array}{ll}6.24 & 2.37\end{array}$

7.101 .91 8.292 .27 $6.05 \quad 2.07$ $7.22 \quad 2.01$ 8.402 .32 6.422 .04 7.202 .41 6.492 .29 8.601 .90 $7.86 \quad 2.10$ 7.652 .10 $7.98 \quad 2.15$ 6.861 .84 $7.67 \quad 1.93$ $7.56 \quad 2.12$ 9.032 .48 7.632 .20 7.102 .08 6.843 .03 $8.38 \quad 3.11$ $7.92 \quad 2.77$ 8.523 .25 8.402 .95 $8.05 \quad 2.79$ $10.16 \quad 5.21$ $6.38 \quad 3.58$ $8.08 \quad 2.73$ 0.000 .00 $9.30 \quad 0.00$ 7.211 .99 $12.35 \quad 4.74$ $0.00 \quad 0.00$ 8.273 .73 0.000 .00 $\begin{array}{ll}7.48 & 2.48\end{array}$ 6.743 .10

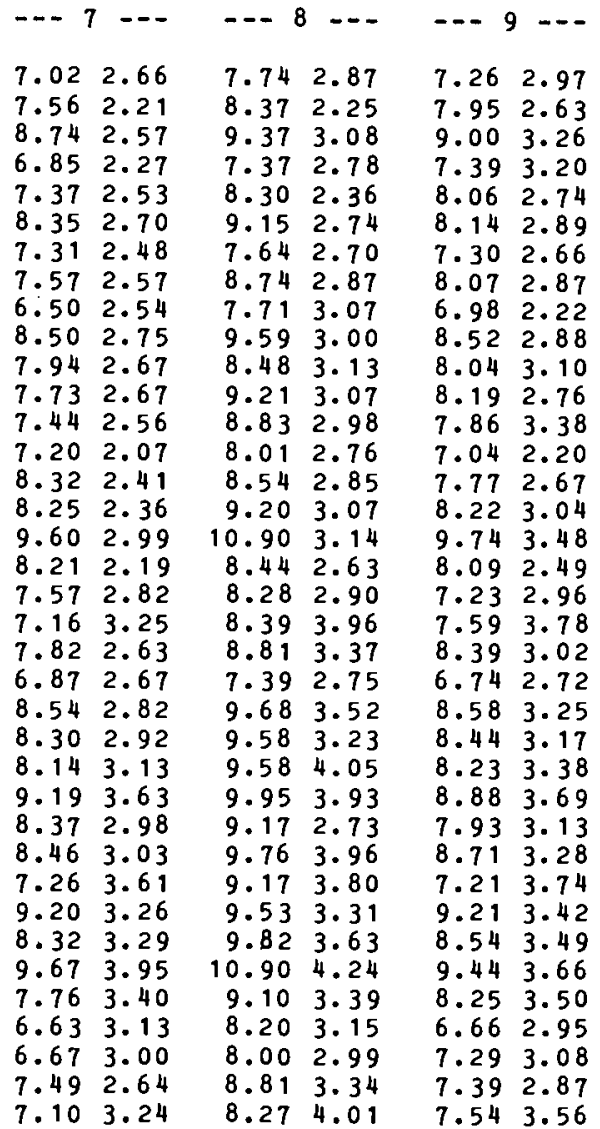


RESULTS

Both the frequency of occurrence of the weather pattern type and the mean wind speed show variations from year to year. An important application of the weather pattern type climatology is to use the interannual variability of the weather pattern type frequency to adjust the observed speed to represent the long-term mean speed. This has meaning only if the year-to-year variability of the mean speed for a given weather pattern type is much less than the year-to-year variability of the frequency of occurrence of the weather pattern type. Figure 10 shows a scatter diagram of the variability of frequency of occurrence and speed for each weather pattern type. Variability is defined as the ratio of the standard deviation of the yearly values divided by the mean of the yearly values. For only a few stations and weather pattern types is the variability of the wind speed greater than that of the frequency of
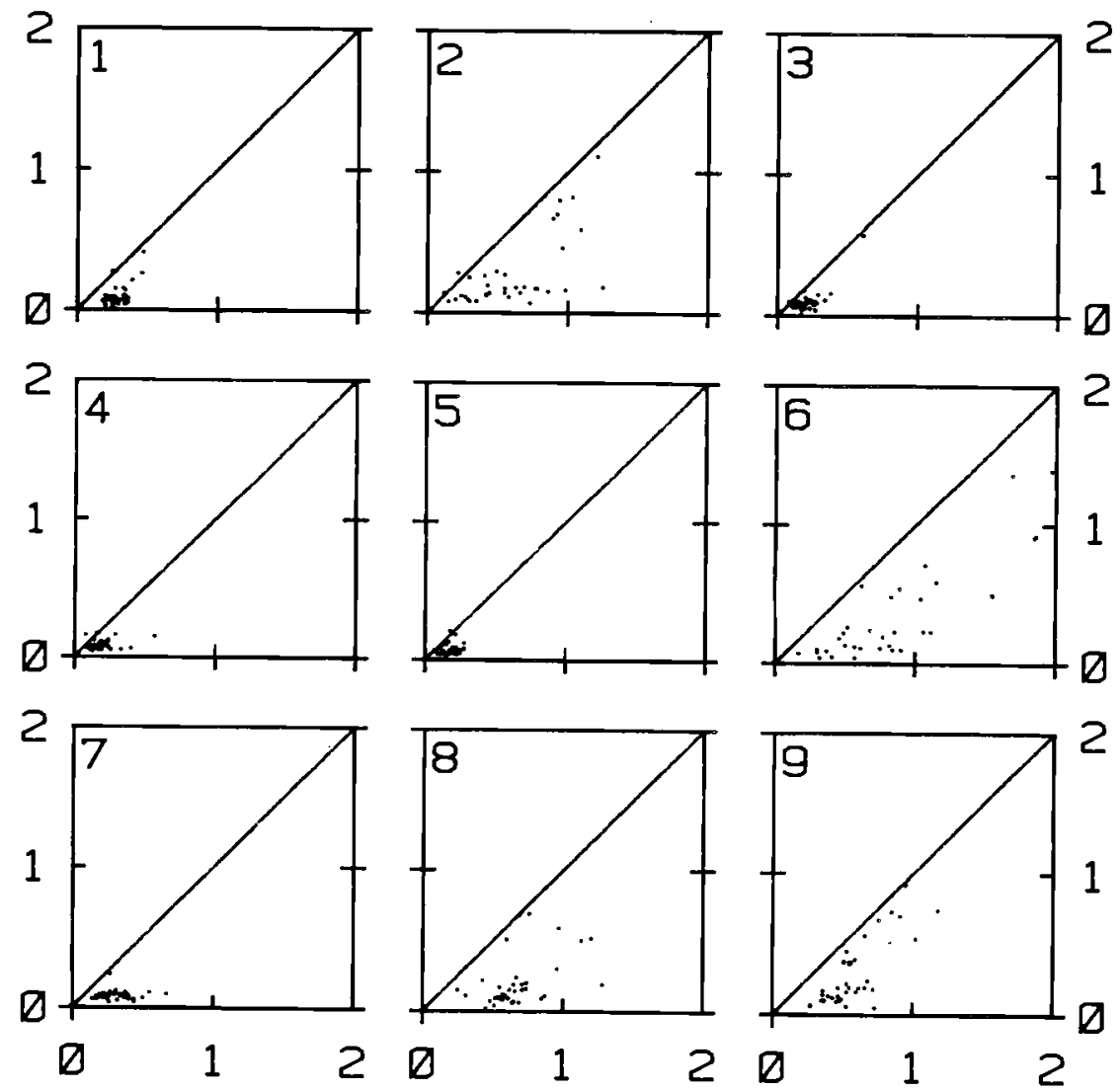

FIGURE 10. Scatter Diagrams by Weather Pattern Type of the Variability of Wind Speed (Ordinate) Versus the Variability of Frequency of Occurrence (Abscissa) 
occurrence. Over all weather pattern types, the speed variability averaged $39 \%$ of the frequency variability. The large scatter and high values of the variability shown in Figure 10 for Types 2, 6, 8 and 9 are due to the low frequency of occurrence of these types, especially at the northern stations. Even for these types, the clustering of a large portion of the points about a low value of the wind variability indicate that where a weather pattern type has importance (i.e., high frequency of occurrence), wind variability is much less than the variability of the frequency of weather pattern occurrence.

Figures 11 and 12, for the same two stations used to portray the monthly trends in weather pattern type frequency, show the interannual variability of the frequency of occurrence and mean wind speed by weather pattern type. The high variability of the frequency of occurrence and the relatively small change in mean speed for a weather pattern type is clearly seen in these figures.

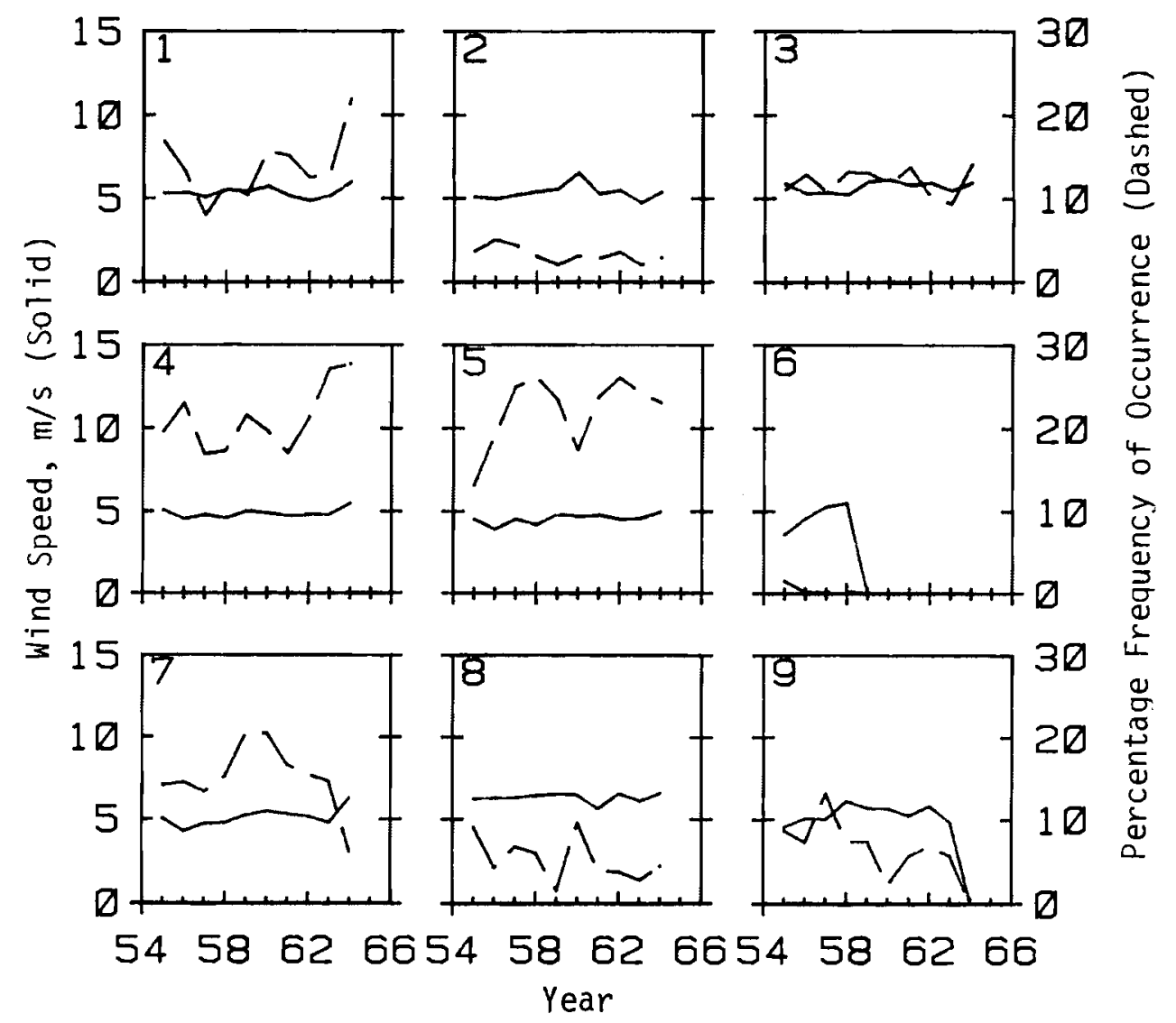

FIGURE 11. Interannual Variability in Frequency of 0ccurrence (dashed) and Mean Wind Speed (solid) for Rapid City, South Dakota 


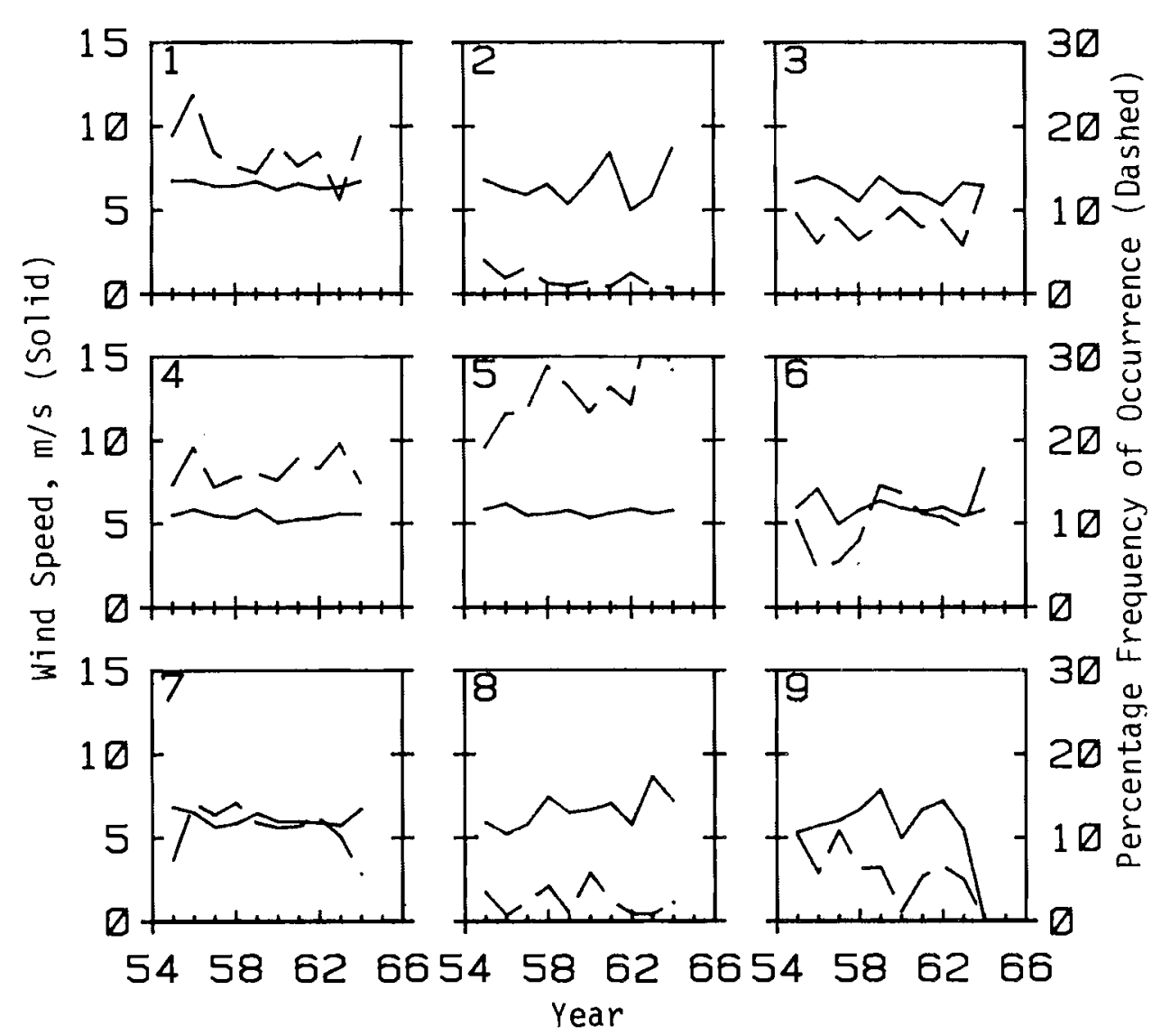

FIGURE 12. Interannual Variability in Frequency of Occurrence (dashed) and Mean Wind Speed (solid) for Oklahoma City, Oklahoma

Mean wind speeds at a station are often nearly the same for pairs of weather pattern types (Table 7). Student's t-test was applied to test the hypothesis that the mean speeds of pairs of weather pattern types were obtained from the same population of wind speed observations. When this hypothesis is accepted, it means stratification by that pair of weather pattern types did not yield substantially different populations of wind observations. Table 13 summarizes the results of the student's t-test for 37 stations/periods of record. For only 14 out of 37 pairs of weather pattern types is the probability greater than $25 \%$ that the two mean wind speeds are from the same population; for 10 pairs it is less than $10 \%$. On the basis of a comparison of just the mean wind speeds, stratification by weather pattern type yields distinctly different wind speeds for about one-third of the 
TABLE 13. Mean Probability (\%) from 37 Stations That the Mean Wind Speed From the Indicated Pairs of Weather Pattern Types Are From the Same Population of Speed Observations

\begin{tabular}{rrrrrrrrr} 
TYPE & \multicolumn{9}{c}{ TYPE } & & $\varepsilon$ & 7 & 6 & 5 & 4 & 3 & 2 \\
1 & 31. & 15. & 25. & 22. & 1. & 6. & 29. & 44. \\
2 & 49. & 27. & 48. & 31. & 21. & 27. & 40. & \\
3 & 29. & 17. & 21. & 17. & 1. & 1. & \\
4 & 12. & 4. & 14. & 36. & 21. & & \\
5 & 5. & 1. & 5. & 32. & & & \\
6 & 22. & 8. & 28. & & & & & \\
7 & 49. & 9. & & & & &
\end{tabular}

possible pairs of weather pattern types. Additional tests of the strength of the stratification, such as a chi-square test on the joint speed-direction frequency distribution, have not been done.

During the early 1960s, the anemometers at many airport National Weather Service stations were moved from rooftop locations to ground masts located on the grass strips between or alongside airport runways. Two periods of record, one for each anemometer height and location, were analyzed for ten stations (see Table 5) in this study. Using wind speed statistics from two anemometer heights, it is possible to determine the apparent change with height of the long-term mean wind speed. Table 14 gives the mean wind speed observed at the two anemometer heights and the corresponding power-law wind shear exponent $(\alpha)$ calculated from:

$$
\alpha=\frac{\ln \left(V_{1} / V_{2}\right)}{\ln \left(z_{1} / z_{2}\right)}
$$

where $z_{1}$ and $z_{2}$ are the two anemometer heights and $v_{1}$ and $v_{2}$ are the two mean wind speeds at these heights. Also noted in Table 14 is the location of the anemometer. In all cases, the change in anemometer height is accompanied by a change in location from rooftop $(R)$ to ground mast $(G)$. 
TABLE 14. Apparent Power Law Shear Exponent for the Long-Term Mean Wind Speed at Ten Great Plains Locations. Wind speeds are in $\mathrm{m} / \mathrm{s}$. Anemometer heights are in $\mathrm{ft} A G L$.

\begin{tabular}{ccccccccc} 
Type & 1 & 2 & 3 & 4 & 5 & 6 & 7 & 8 \\
\hline W24143 & \multicolumn{1}{c}{ Great Fal1s, MT } & \multicolumn{3}{c}{$\mathrm{Z}_{1}=75^{\prime} \mathrm{R}$} & \multicolumn{2}{c}{$\mathrm{Z}_{2}=22^{\prime} \mathrm{G}$} \\
$\mathrm{V}_{1}$ & 7.81 & 7.72 & 6.48 & 7.80 & 5.58 & - & 6.36 & 7.35 \\
$\mathrm{~V}_{2}$ & 5.91 & 5.36 & 5.38 & 5.84 & 4.58 & - & 5.10 & 6.09 \\
$\alpha$ & 0.227 & 0.297 & 0.152 & 0.236 & 0.161 & & 0.180 & 0.153
\end{tabular}

\begin{tabular}{clllllllll} 
W24144 & Helena, MT & \multicolumn{3}{c}{$\mathrm{Z}_{1}=44^{\prime} \mathrm{R}$} & \multicolumn{2}{c}{$\mathrm{Z}_{2}=20^{\prime} \mathrm{G}$} \\
$\mathrm{V}_{1}$ & 4.09 & 3.70 & 4.40 & 3.78 & 3.01 & - & 3.73 & 4.82 \\
$\mathrm{~V}_{2}$ & 4.07 & 3.22 & 4.16 & 3.68 & 3.24 & - & 3.75 & 4.43 \\
$\alpha$ & 0.006 & 0.176 & 0.071 & 0.034 & 0.093 & & 0.007 & 0.107 \\
\hline
\end{tabular}

\begin{tabular}{cllllllll} 
W24027 & \multicolumn{3}{l}{ Rock Springs, WY } & \multicolumn{3}{c}{$Z_{1}=50^{\prime}$} & & \multicolumn{2}{c}{$Z_{2}=20^{\prime} G$} \\
$V_{1}$ & 6.06 & 6.20 & 6.48 & 6.02 & 4.68 & 7.01 & 5.96 & 6.54 \\
$V_{2}$ & 5.70 & 6.01 & 5.66 & 5.42 & 4.49 & 4.36 & 5.57 & 6.27 \\
$\alpha$ & 0.067 & 0.034 & 0.148 & 0.115 & 0.045 & 0.518 & 0.074 & 0.046
\end{tabular}

\begin{tabular}{cllllllll}
\hline W23062 & Denver, C & \multicolumn{3}{c}{$\mathrm{Z}_{1}=72^{\prime}$} & $\mathrm{R}$ & \multicolumn{2}{c}{$\mathrm{Z}_{2}=20^{\prime} \mathrm{G}$} \\
$\mathrm{V}_{1}$ & 5.12 & 5.40 & 5.23 & 4.92 & 4.54 & 4.86 & 4.81 & 5.34 \\
$\mathrm{~V}_{2}$ & 4.29 & 4.32 & 4.26 & 4.01 & 3.74 & 5.12 & 4.20 & 4.61 \\
$\alpha$ & 0.138 & 0.174 & 0.160 & 0.160 & 0.151 & 0.041 & 0.106 & 0.115
\end{tabular}

\begin{tabular}{llllllllll}
\hline W14935 & \multicolumn{3}{c}{ Grand Island, NE } & \multicolumn{3}{c}{$Z_{1}=47^{\prime}$} & & \multicolumn{2}{c}{$Z_{2}=20^{\prime} G$} \\
$V_{1}$ & 6.15 & 6.53 & 5.93 & 5.18 & 5.50 & 5.92 & 5.86 & 6.78 \\
$V_{2}$ & 5.65 & 5.51 & 5.31 & 4.83 & 5.00 & 5.06 & 5.34 & 5.93 \\
$\alpha$ & 0.099 & 0.199 & 0.129 & 0.082 & 0.112 & 0.184 & 0.109 & 0.157 \\
\hline
\end{tabular}


TABLE 14 (continued)

\begin{tabular}{|c|c|c|c|c|c|c|c|c|}
\hline Type & 1 & 2 & 3 & 4 & 5 & 6 & 7 & 8 \\
\hline W14933 & \multicolumn{3}{|c|}{ Des Moines, IA } & \multicolumn{3}{|c|}{$z_{1}=69 \cdot R$} & \multicolumn{2}{|c|}{$Z_{2}=20^{\prime} \mathrm{G}$} \\
\hline$v_{1}$ & 5.51 & 6.06 & 6.21 & 4.93 & 4.92 & 5.03 & $5.14^{\circ}$ & 6.29 \\
\hline$v_{2}$ & 5.19 & 4.61 & 4.85 & 4.29 & 4.39 & 4.43 & 4.31 & 5.45 \\
\hline$\alpha$ & 0.048 & 0.221 & 0.200 & 0.112 & 0.092 & 0.103 & 0.142 & 0.116 \\
\hline W23048 & \multicolumn{3}{|c|}{ Tucumcari, NM } & \multicolumn{3}{|c|}{$z_{1}=32^{\prime} R$} & \multicolumn{2}{|c|}{$Z_{2}=22^{\prime} G$} \\
\hline$v_{1}$ & 5.94 & 5.67 & 5.90 & 5.12 & 5.24 & 5.09 & 5.62 & 5.86 \\
\hline$v_{2}$ & 5.12 & 4.06 & 5.01 & 4.41 & 4.57 & 4.80 & 4.98 & 5.54 \\
\hline$\alpha$ & 0.396 & 0.891 & 0.436 & 0.398 & 0.365 & 0.157 & 0.323 & 0.150 \\
\hline W23047 & \multicolumn{3}{|c|}{ Amarillo, TX } & \multicolumn{3}{|c|}{$z_{1}=33^{\prime} \mathrm{R}$} & \multicolumn{2}{|c|}{$Z_{2}=23^{\prime} \mathrm{G}$} \\
\hline$v_{1}$ & 5.89 & 5.42 & 5.69 & 5.17 & 5.32 & 5.09 & $5.61^{-}$ & 6.31 \\
\hline$v_{2}$ & 6.45 & 5.52 & 6.49 & 5.85 & 6.30 & 6.12 & 6.52 & 7.80 \\
\hline$\alpha$ & $<0$ & $<0$ & $<0$ & $<0$ & $<0$ & $<0$ & $<0$ & $<0$ \\
\hline W23023 & \multicolumn{3}{|c|}{ Midland, TX } & \multicolumn{3}{|c|}{$\mathrm{z}_{1}=35^{\prime} \mathrm{R}$} & \multicolumn{2}{|c|}{$Z_{2}=22^{\prime} \mathrm{G}$} \\
\hline$v_{1}$ & 4.75 & 4.65 & 5.20 & 4.24 & 4.49 & 4.46 & $4.79^{\circ}$ & 5.34 \\
\hline$v_{2}$ & 5.34 & 5.29 & 5.48 & 4.84 & 4.97 & 5.05 & 5.58 & 5.71 \\
\hline$\alpha$ & $<0$ & $<0$ & $<0$ & $<0$ & $<0$ & $<0$ & $<0$ & $<0$ \\
\hline W13968 & \multicolumn{3}{|c|}{ Tulsa, OK } & \multicolumn{3}{|c|}{$Z_{1}=39^{\prime} R$} & \multicolumn{2}{|c|}{$Z_{2}=23^{\prime} \mathrm{G}$} \\
\hline$v_{1}$ & 4.89 & 4.92 & 5.14 & 4.42 & 4.10 & 4.01 & $4.50^{-}$ & 5.04 \\
\hline$v_{2}$ & 5.63 & 5.44 & 5.12 & 4.71 & 4.98 & 4.96 & 5.05 & 5.97 \\
\hline$\alpha$ & $<0$ & $<0$ & 0.007 & $<0$ & $<0$ & $<0$ & $<0$ & $<0$ \\
\hline
\end{tabular}


To properly interpret the shear exponent given in Table 14, it is necessary to recognize that the wind regime is very sensitive to the local surroundings of the measurement site. Thus, the buildings in the vicinity of the building on which the anemometer is located act as roughness elements to the wind and often cause such a marked reduction in wind speed, even at anemometer height, that a change in location to an unobstructed airport runway setting will result in a higher mean wind speed in the new location. Any location that shows unusually small or large shear exponents must be evaluated very carefully. Amarillo and Midland, Texas, where the anemometer height change is only about 10 feet, and Tulsa, Oklahoma, have very unrealistic negative shear exponents for all weather pattern types. This is most likely caused by the decrease in surface roughness in the change to the airport location. Denver, Colorado, and Helena, Montana, have negative shear exponents for some weather pattern types. At Denver, the negative shear for Type 6 is probably the result of the very small sample size available for this type, only $0.79 \%$ of observations in the first period and $0.67 \%$ in the second. At Helena the sample size is not the problem. Here it is the sensitivity of the wind speed to the directional variation of anemometer exposure. Figures 13 and 14 show the directional frequency for each weather pattern type and the mean wind speed from that direction for the two periods of record from Helena, Montana. Notice that for weather pattern Type 5, the directional frequencies for the two periods are very similar but the winds from the east are much higher in the first period than in the second. The wind speed from the prevailing direction, which is the same for both periods, is much less during the first period in comparison to the second. These differences in response to wind direction are most often caused by changes in anemometer exposure that are highly site-specific. 


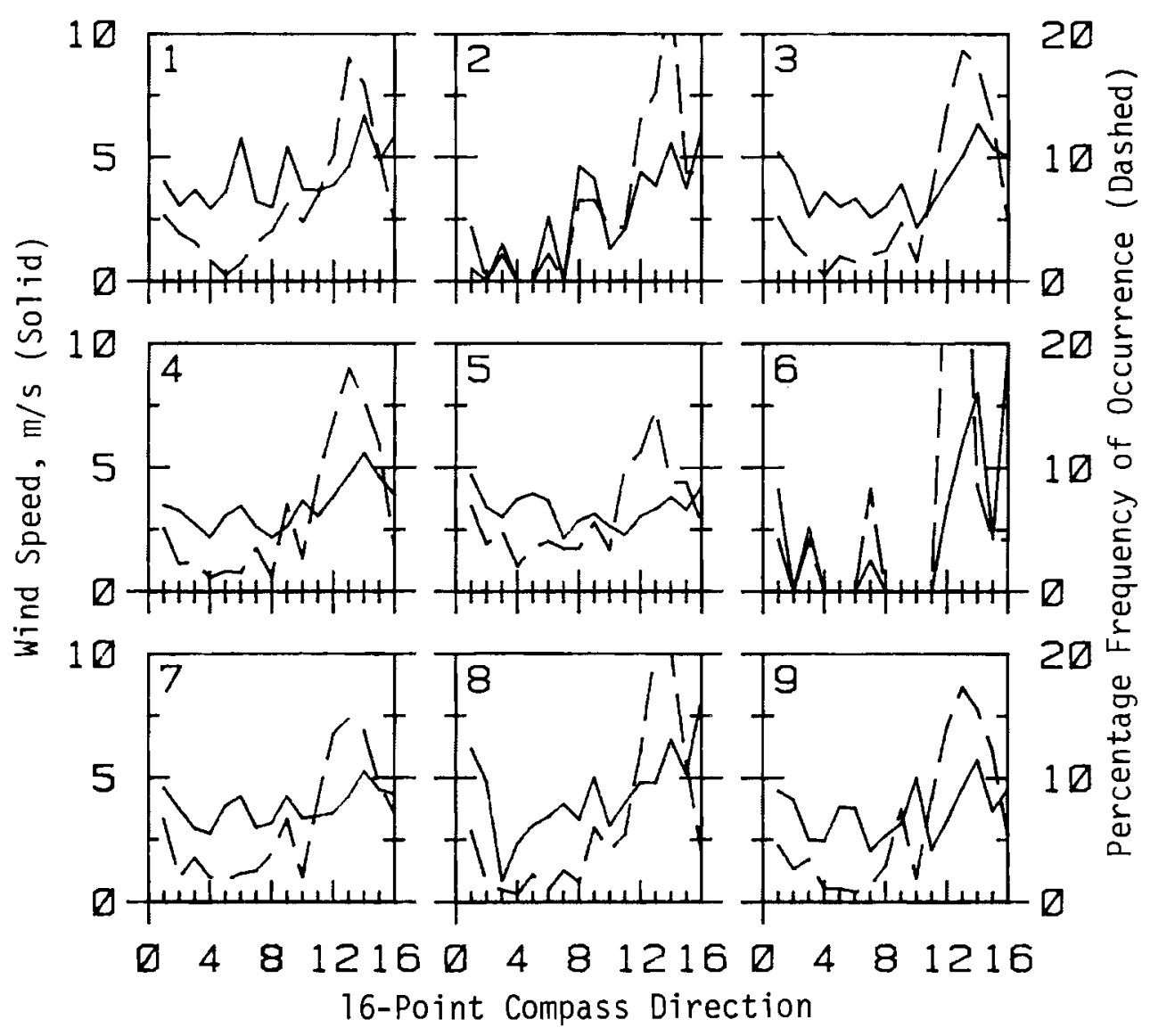

FIGURE 13. Wind Direction Frequency and Mean Wind Speed by Direction for the Period January 1, 1955 to September 19, 1961 at Helena, Montana. Anemometer height is 44 feet AGL on rooftop mast. 


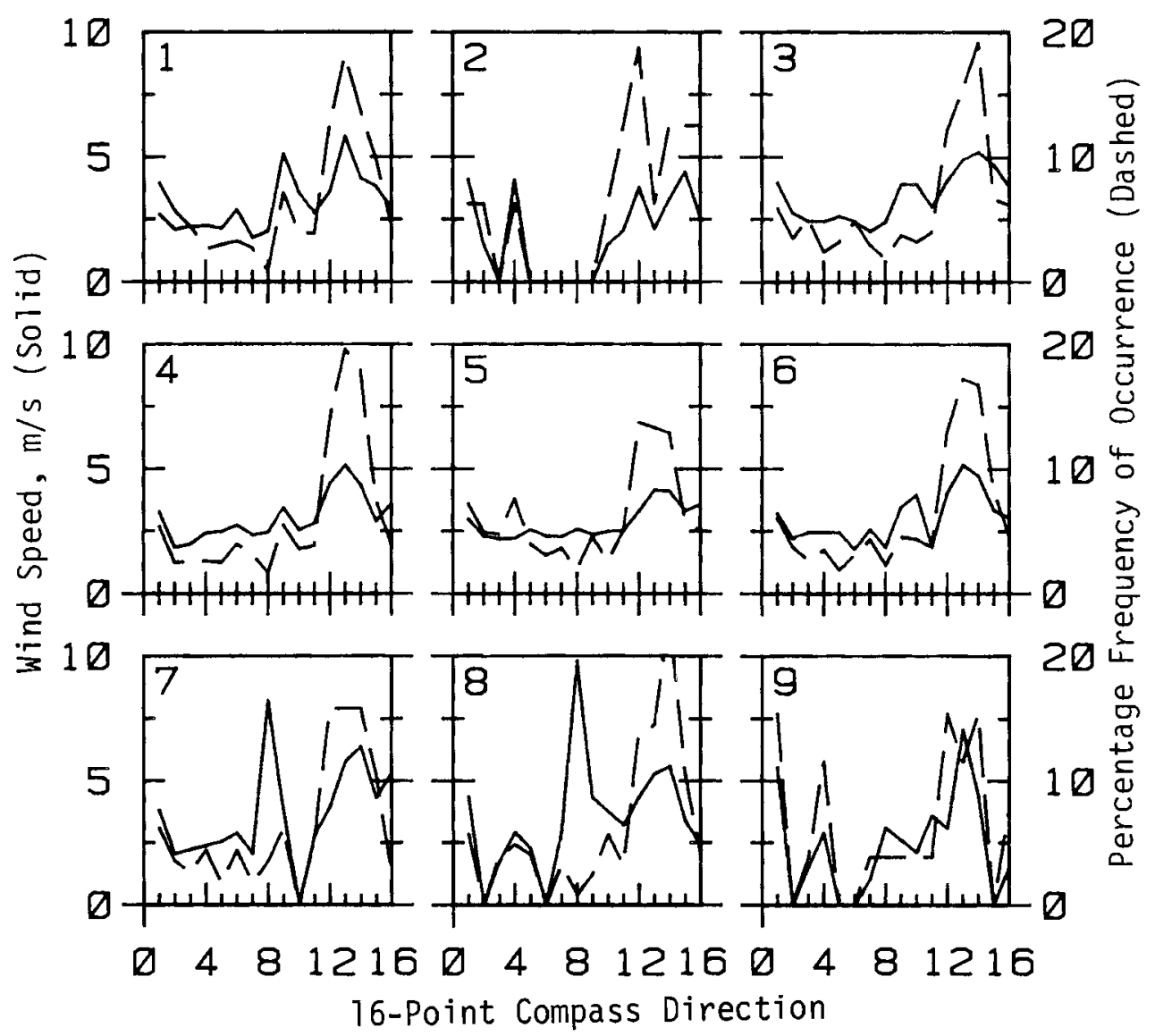

FIGURE 14. Wind Direction Frequency and Mean Wind Speed by Direction for the Period September 20, 1961 to December 31, 1964 at Helena, Montana. Anemometer height is 20 feet AGL on ground mast. 
DISCUSSION AND CONCLUSIONS

\section{WEATHER PATTERN CLIMATOLOGY}

The synoptic model presented in Figure 1 and the abbreviated definitions given in Table 1 provide a useful framework for stratifying Great Plains weather patterns. However, considerable experience with synoptic meteorology is essential in order to consistently type weather patterns. There must be consistency across a map. There must be consistency from map to map. And there must be consistency relative to all meteorological variables, not just the pressure pattern. Additional guidelines for achieving the needed consistency will be presented in a future report on the conterminous United States weather pattern climatology.

Frequency of occurrence of weather pattern types over the Great Plains is determined by the position of major frontal systems. Figures 6 to 9 show the season variation of the frequency of occurrence. Variations track the north-south movement of the polar front and seasonal cyclonic storm tracks. The position of the polar front and the location of major storm tracks effectively separate the Great Plains into northern and southern regions. The southern region is distinguished by the high frequency of occurrence of the subtropical high (Type 6) and low frequency of occurrence of "north-ofthe-front" weather pattern types (Types 1, 2, 3, 8).

The "catch-a11" weather pattern type - indeterminate (Type 9) - has a distinct maximum over southwestern Texas during the warm months. A thermal low appears in the sea-level pressure pattern over the high inland desert of northern Mexico during these months. This pattern does not fit weather pattern types based on a moving air mass/cyclone model as in Figure 1 . The thermal low is most noticeable during periods of relatively weak pressure gradients such as might be found in Types 1,5 and 6 . The alternation of these types with Type 9 is illustrated in Table 15 for Carlsbad, New Mexico. The percentage of alternation to Type 9 is substantially higher at Carlsbad than at Rapid City (Table 4). It can be shown from Part C of Table 15 that $80 \%$ of Type 9 runs that begin at noon came from a run of Types 1, 5 or 6 . 
TABLE 15. Frequency of Alternation From Weather Pattern Type I (Row) to Weather Pattern Type J (Column) at Carlsbad, New Mexico, as the Percentage of Runs That Change From Type I to Type $\mathrm{J}$

\begin{tabular}{|c|c|c|c|c|c|c|c|c|c|}
\hline \multirow{2}{*}{$\begin{array}{c}\text { TYPE } \\
I\end{array}$} & \multicolumn{9}{|c|}{ TYPE J } \\
\hline & 1 & 2 & 3 & 4 & 5 & 6 & 7 & 8 & 9 \\
\hline 1 & 0.0 & 0.6 & 25.4 & 11.5 & 16.6 & 12.8 & 16.4 & 1.0 & 14.5 \\
\hline 2 & 18.8 & 0.0 & 25.0 & $6 \cdot 3$ & $6 \cdot 3$ & 6.3 & 12.5 & 0.0 & 25.0 \\
\hline 3 & 15.4 & 1.8 & 0.0 & 11.8 & 36.6 & 5.7 & 16.1 & 4.7 & $7 \cdot 9$ \\
\hline 4 & 26.0 & 0.4 & 4.8 & 0.0 & 33.2 & 10.8 & 6.0 & 2.8 & 16.0 \\
\hline 5 & 35.1 & 0.7 & 4.8 & 16.9 & 0.0 & 10.0 & 7.8 & 4.1 & 19.7 \\
\hline 6 & 35.2 & 0.4 & 14.1 & 5.7 & 11.9 & 0.0 & 16.7 & 0.9 & 13.2 \\
\hline 7 & 25.7 & 0.4 & 14.5 & 7.4 & 26.4 & 10.8 & 0.0 & 4.5 & 9.7 \\
\hline 8 & 25.0 & 0.0 & 15.6 & 10.9 & 18.8 & 4.7 & 17.2 & 0.0 & 7.8 \\
\hline 9 & 26.7 & 0.3 & 7.8 & 12.8 & 25.0 & $12 \cdot 5$ & 11.8 & 2.0 & 0.0 \\
\hline RUNS & 524 & 16 & 279 & 250 & 461 & 227 & 269 & 64 & 296 \\
\hline
\end{tabular}

Part B: Noon to noon alternation

TYPE

$$
\text { I }
$$

1
0.0
29.6
14.2
25.8
26.7
28.6
28.0
11.4
28.9

2

\begin{abstract}
1.025 .8
\end{abstract}
1.0

$0.0 \quad 25.9$

$\begin{array}{ll}1.9 & 0.0 \\ 0.3 & 6.2\end{array}$

1.4

6.2

0.0

6.9

$12 \cdot 7$

$\begin{array}{ll}1.5 & 20.1\end{array}$

0.020 .5

1.0

9.9

485 $\begin{array}{lrl}4 & \text { TYPE J } \\ 4 & 5\end{array}$

6

$11.8 \quad 16.7$

6.621 .2

0.014 .8

$5.2 \quad 20.4$

$5.5 \quad 7.2$

$4.7 \quad 14.5$

0.015 .9

3.5

6.8

15.9
0.0

29.5

16.0

14.619 .0

6.2

$126 \quad 343$

$\begin{array}{rr}8 & 9 \\ & \\ 1.0 & 14.8 \\ 0.0 & 11.1 \\ 1.0 & 8.4 \\ 2.1 & 13.7 \\ 3.5 & 19.6 \\ 2.4 & 19.0 \\ 2.0 & 8.2 \\ 0.0 & 2.3 \\ 1.0 & 0.0\end{array}$

$44 \quad 294$ 
TABLE 15 (continued)

\begin{tabular}{|c|c|c|c|c|c|c|c|c|c|}
\hline TYPE & & & & & TYPE J & & & & \\
\hline$I$ & 1 & 2 & 3 & 4 & 5 & 6 & 7 & 8 & 9 \\
\hline 1 & 0.0 & 1.8 & 23.0 & 10.6 & 15.0 & $7 \cdot 9$ & 18.7 & 1.8 & 20.1 \\
\hline 2 & 6.7 & 0.0 & 20.0 & 0.0 & $13 \cdot 3$ & 6.7 & 40.0 & 0.0 & $13 \cdot 3$ \\
\hline 3 & 17.7 & 2.5 & 0.0 & 16.9 & 27.4 & 4.2 & 22.8 & 1.3 & 7.2 \\
\hline 4 & 13.9 & 0.0 & 5.6 & 0.0 & 46.8 & 4.2 & 9.3 & 1.9 & $18 \cdot 5$ \\
\hline 5 & 25.8 & 1.0 & 4.2 & 26.0 & 0.0 & 4.4 & $14 \cdot 3$ & 2.9 & $20 \cdot 3$ \\
\hline 6 & 28.7 & 0.0 & 7.0 & 6.1 & 16.8 & 0.0 & 18.9 & 2.4 & 18.9 \\
\hline 7 & 26.3 & 1.7 & $15 \cdot 3$ & $12 \cdot 3$ & 26.7 & 3.4 & 0.0 & 3.4 & 10.6 \\
\hline 8 & 17.2 & 0.0 & 21.9 & 15.6 & 14.1 & 0.0 & 29.7 & 0.0 & 1.6 \\
\hline 9 & 26.4 & 1.0 & 10.2 & 15.8 & 22.4 & 6.6 & 14.5 & 2.0 & 0.0 \\
\hline RUNS & 508 & 15 & 237 & 216 & 384 & 328 & 236 & 64 & 303 \\
\hline
\end{tabular}

Part D: Noon to midnight alternation

\begin{tabular}{|c|c|c|c|c|c|c|c|c|c|}
\hline TYPE & & & & & Y PE & & & & \\
\hline$I$ & 1 & 2 & 3 & 4 & 5 & 6 & 7 & 8 & 9 \\
\hline 1 & 0.0 & 0.0 & $27 \cdot 3$ & 6.1 & 10.8 & 23.1 & 15.2 & 2.0 & 15.5 \\
\hline 2 & 15.4 & 0.0 & 26.9 & 3.8 & 23.1 & 3.8 & 11.5 & 11.5 & 3.8 \\
\hline 3 & 13.7 & 1.2 & 0.0 & 16.9 & 26.6 & 5.6 & 22.2 & 4.0 & 9.3 \\
\hline 4 & 24.8 & 0.3 & 2.6 & 0.0 & 41.9 & 10.6 & 4.8 & 1.9 & 12.9 \\
\hline 5 & 29.6 & 1.1 & 4.2 & 20.0 & 0.0 & 12.7 & 10.0 & 3.1 & 19.2 \\
\hline 6 & 47.6 & 0.0 & 7.6 & 9.5 & 12.4 & 0.0 & 10.5 & 1.0 & 11.4 \\
\hline 7 & $24 \cdot 3$ & 1.2 & 12.0 & 6.4 & 21.3 & 18.4 & 0.0 & 5.0 & 11.1 \\
\hline 8 & 28.3 & 0.0 & 13.0 & 8.7 & 21.7 & 10.9 & 8.7 & 0.0 & 8.7 \\
\hline 9 & 32.5 & 0.7 & 10.5 & 9.5 & $16 \cdot 3$ & 20.3 & 9.2 & 0.7 & 0.0 \\
\hline NS & 407 & 26 & 248 & 310 & 449 & 105 & 342 & 46 & 295 \\
\hline
\end{tabular}


Further, from Part D of Table 15,78\% of runs of Types 1,5 and 6 that began at midnight came from a run of Type 9.

Nearly all weather pattern types show a large variability in their yearto-year frequency of occurrence. As shown in Figure 10, the variability is highest for the least frequently occurring weather pattern types $(2,6,8$ and 9). For most of the stations analyzed, the interannual variability shows no definite trend over the 10-year period of study. However, Type 9 shows a trend towards lower frequency of occurrence (see Figures 11 and 12 for example). This could be real or it could be the result of improving discrimination of weather pattern types as the analysts of the weather maps gained experience.

\section{WIND REGIME}

The wind regimes associated with various weather patterns were examined for 37 stations or periods of record. Tables 6 through 12 give some of the statistics determined for each weather pattern type. A 12-hour mean centered on the map time of the hourly wind speeds (Table 7) results in an overall mean wind speed for a weather pattern type that has a lower standard deviation than the mean of the map-time speeds (Table 6).

Resultant wind directions, as determined from Tables 8 and 9, fit the synoptic model fairly well. Departures from the expected synoptic model directions may be due to local topography or to the mean position of major air masses. For example, Types 5 and 6 winds at most locations have a large southerly (from the south) component but may have either a small westerly or easterly component (see Tables 8 and 9). Another useful aspect of Tables 8 and 9 is that the resultant wind speed (square root of sum of squared speeds) along with the scalar mean speed (Table 7 ) provides a measure of the variability of wind direction:

$$
\sigma_{\theta}=\sin ^{-1} \sqrt{T-R / V}
$$


where $R$ is the resultant speed and $V$ is the scalar mean speed. Low values of $R$ imply high directional variability.

Anemometer height changes at National Weather Service stations during. the study period were usually accompanied by a move from rooftop to ground mast. The change in exposure and surrounding surface roughness made extimates of the shear of the long-term mean wind from mean wind speeds at the two anemometer heights highly unreliable. At those stations at which the power law shear exponent was a reasonable value, substantial differences between weather pattern types were noted. These differences may be ascribed to surface roughness varying by direction and to the thermal stability associated with the weather pattern.

Stratification by weather pattern type provides some discrimination of different wind regimes. The very simple student's t-test showed (Table 13) that the mean wind speeds (Table 7) are from different sample populations with greater than $75 \%$ confidence for two-thirds of the possible pairs of weather pattern types. Even so, the differences in mean wind speed between weather pattern types are relatively small (less than $1 \mathrm{~m} / \mathrm{s}$, usually). These results indicate that at Great Plains locations mean wind speed is not a good indicator of weather pattern type. Also, the use of a scalar indicator, such as the mean speed, omits the directional character of the wind from the test for a difference between weather pattern type. An inherent shortcoming of the stratification by weather pattern type is that the intensity of the pressure gradient that drives the large-scale synoptic wind field is not parameterized. Examination of Table 6 or 7 shows that Type 8, which occurs near the center of a cyclonic storm, has the highest mean speeds and mean maximum speeds for more than $80 \%$ of the stations analyzed. Type 8 is also most likely associated with the strongest pressure gradients among the various weather pattern types.

Weather pattern typing is a useful tool for identifying the major weather patterns that give rise to the wind regime at a site. However, the mean wind speed is not a highly reliable discriminator between weather pattern types. 



\section{DISTRIBUTION}

No. of

Copies

D. Ancona

Department of Energy

Wind Energy Technology Division

1000 Independence Avenue

Forrestal Building, Room 5F059

Washington, DC 20585

C. I. Aspliden

Battelle Memorial Institute

Washington Operations Otfice

2030 M Street, N.W.

Washington, DC 20036

J. Cadogan

Department of Energy

Wind Energy Technology Division

1000 Independence Avenue

Forrestal Building, Room 5F059

Washington, DC 20585

G. P. Tennyson

Department of Energy

Albuquerque Operations Office

P.0. Box 5400

Albuquerque, NM 87110

27 DOE Technical Information Center

Dr. K. C. Spengler

American Meteorological Society

45 Beacon Street

Boston, MA 02108

Tom Gray

American Wind Energy Association

1621 Connecticut Avenue, N:W.

Washington, DC 20009

Richard Katzenberg

3100 Highland Place

Washington, DC 20008

E. J. Warchol

Bonneville Power Administration

P. 0. Box 3621

Portland, OR 97208
No. of

Copies

S. J. Hightower

Bureau of Reclamation

Denver Federal Center

Building 67, Code 254

Denver, CO 80225

Dr. T. McKee

Atmospheric Science Department

Colorado State University

Fort Collins, CO 80521

R. Nolan Clark

Department of Agriculture

S.W. Great Plains

Research Center

Bushland, TX 79012

Dr. Edgar DeMeo

Electric Power Research Institute 3412 Hillview Avenue

Palo Alto, CA 94303

Thomas R. Hiester

Flow Research

21414 68th Avenue, South

Kent, WA 98031

Dr. Wayne Wendland

Illinois State Water Survey

P.0. Box 232

Urbana, IL 61801

James $D$. West

HQ MAC/DEEE

Scott AFB, IL 62225

Gary G. Worley, Maj. USAF

HQ AF-ESC/RDVA

Tynda11 AFB, FL 32403

Gary L. Johnson

Electrical Engineering Department Kansas State University

Manhattan, KN 66506 
No. of

Copies

Marlatt and Associates

3611 Richmond Drive

Fort Collins, CO 80521

J. Konigsberg

Montana Energy Office

Capital Station

Helena, MT 59601

Phillip French

NASA Scientific and Technical

Information Facility

P.0. Box 8757

Baltimore/Washington International Airport

Baltimore, MD 21240

R. A. Wolf

NASA/Lewis Research Center

Mail Stop 500-201

Cleveland, $\mathrm{OH} 44135$

M. J. Changery

National Oceanic and Atmospheric

Administration

National Climatic Center

Federal Building

Asheville, NC 28801

C. F. Chappe 11

Office of Weather Research and Modification

National Oceanic and Atmospheric Administration

Boulder, CO 80303

Dr. N. J. Rosenberg

211 Agricultural Engineering Bldg.

University of Nebraska

Lincoln, NE 68583

Prof. J. W. Eng

Department of Soils

Welster Hall

North Dakota State University

Fargo, ND 58102

Dr. A. Eddy

University of $0 \mathrm{klahoma}$

200 Felgar Street, Room 219

Norman, OK 73069
No. of

Copies

E. W. Hewson/J. E. Wade

Atmospheric Sciences Department

Oregon State University

Corvallis, OR 97331

Terry J. Healy

Rockwell International

Rocky Flats Plant

P.0. Box 464

Golden, C0 80401

E. Kadlec

Sandia Laboratories

Division 5443

P.0. Box 5800

Albuquerque, NM 87115

Dr. P. F. Lester

Department of Meteorology

San Jose State University

San Jose, CA 95192

W. A. Tolbert, Capt. USAF

SERI Site Office/RTLO

1617 Cole Boulevard

Golden, C0 80401

Solar Energy Research Institute

1617 Cole Boulevard

Golden, C0 80401

Mr. Earl L. Kuehnast

Crops Research B1dg., Room 127

University of Minnesota

St. Paul, MN 55101

N. E. Suhs

Tennessee Valley Authority

1360 Commerce Union Bank Building

Chattanooga, TN 37401

Prof. W. Lytle

Agricultural Engineering Bldg.

South Dakota State University

Brookings, SD 57006

Prof. J. F. Griffiths

D\&M Building, Room 1027

Texas A\&M University

College Station, TX 77843 
No. of

Copies

Dr. N. K. Wagner

Department of Civil Engineering

University of Texas

Austin, TX 78712

Dr. Michael Garstang

Department of Environmental Sciences

University of Virginia

Charlottesville, VA 22903

G. D. Thomann

Wichita State University

P.0. Box 44

Wichita, KS 67208

Farrell Smith Seiler

Wind Energy Report

Box 14 - 104 S. Village Avenue

Rockville Centre, NY 11571

W. Van Dyke

Wind Farms, Ltd.

639 Front Street

San Francisco, CA 94111

Dr. Lyle Horn

Department of Meteorology

University of Wiscons in

1225 W. Dayton

Madison, WI 53706

Dr. J. Marwitz

Department of Atmospheric Science

University of Wyoming

Laramie, WY 82071

Richard L. Berry

Atmospheric Environment

4905 Dufferin Street

Downsview, Ontario

M3H 5 T4

CANADA

Dr. Neil Cherry

Lincoln College

Canterbury

NEW ZEALAND
No. of

Copies

ONSITE

1 DOE Richland Operations Office P.0. Box 550

Richland, WA 99352

H. E. Ransom

43 Pacific Northwest Laboratory Battelle Boulevard

Richland, WA 99352

W. R. Barchet

J. W. Buck

D. B. Cearlock

J. R. Connell

J. C. Doran

C. E. Elderkin

D. L. Elliott

W. J. Formica

R. L. George

D. L. Hadley

S. K. Heflick

A. H. Miller

E. L. Owczarski

D. C. Powell

J. J. Praino

D. S. Renne

W. F. Sandusky

H. L. Wegley

L. L. Wendel1

R. K. Woodruff

Technical Information -

Library (5)

Publishing Coordination (2)

WCPE Program Office (15)

2400 Stevens Library (1) 
